\title{
ALGUNAS CONSIDERACIONES SOBRE LA PENA DE AZOTES DURANTE LOS SIGLOS XVI-XVIII.
}

por

\author{
Pedro ORTego GIL \\ Universidad de Santiago
}

RESUMEN: La pena de azotes, una de las penas corporales con mayor historia, conllevaba una singular nota de ignominia para quienes la sufrían, por lo que era especialmente temida. Distinta de esta pena era la corrección de azotes, diferencia basada sobre todo en el número. No puede considerarse pena accesoria de otras sino establecida en composición con ellas. Además, no siempre se imponía junto con la pena de galeras o de destierro, a pesar de las previsiones legales, puesto que el arbitrio judicial redujo su imposición en la práctica. Como consecuencia de lo anterior, representa un porcentaje reducido, al menos, en la Real Audiencia de Galicia sobre el total de sanciones impuestas. Su ámbito de aplicación fue muy extenso, pero destaca sobre todo en materia de burto y para aquellos delincuentes que, en terminología actual, llamaríamos babituales. Su desaparición, propuesta desde la época ilustrada, se debió tanto a las disposiciones legales como al desuso en su aplicación.

Palabras clave: Pena de azotes. Ley penal. Arbitrio judicial. Audiencia de Galicia.

ABSTRACT: Punishment by whipping, one of the corporal punishments with the longest history, was a singularly shameful fate for those who suffered it, as it was especially feared. $A$ different form of this punishment was correction by lashing, the difference being essentially numerical. It cannot be considered an accessory to other punisbments, being part of a combination of them. Also, it was not always imposed together with the punishment of being sent to the galleys, or of exile, in spite of the legal doctrine, since in practice, judicial discretion reduced its imposition. As a consequence of this, it represents a reduced percentage, at least, in the Real Audiencia de Galicia, of the total of imposed sanctions. The scope of the application of this punishment was very extensive, notably for theft and for those criminals that, in current terminology, would be called habitual. Its disappearance, from the end of the eighteenth century, was due as much to legal stipulations as to the disuse of its application.

KEY WORDS: Punishment. Whipping. Criminal law. Judicial discretion. Real Audiencia. Galicia.

Hispania, LXII/3, núm. 212 (2002) 849-906 


\section{VISIÓN GENERAL}

La flagelación con la que se ha castigado a lo largo de la historia a hombres y mujeres es, sin duda, una de las penas más antiguas que han existido. Azotaban los jueces a los reos condenados, los maestros a los aprendices, los oficiales a los desertores, incluso los padres a sus hijos. En la práctica totalidad de los textos religiosos más antiguos hay constancia de su aplicación ${ }^{1}$. Son contados los territorios en los que no se ha impuesto, aunque también sean hoy contados aquellos en los que, por desgracia, se continúa ejecutando tan cruel medida punitiva.

Nuestro interés se centra en acercarnos a la visión que, de este castigo, se tuvo a partir de la perspectiva legal, en su práctica judicial a tenor de la información conservada de los jueces gallegos durante los siglos XVI-XVIII y desde la conciencia popular en los territorios castellanos.

La pena de azotes siempre fue considerada como corporal, sin que faltara jurista que la equipara a la muerte natural: «Quae dicatur poena corporalis? Et breviter et resolutive dico, quod poena mortis naturalis; sed poena abscisionis membri, vel poena flagellorum, vel etiam poena galearum, vel etiam sola poena infamiae, quia aequiparatur morti naturali» ${ }^{2}$. Adviértase que, con sujeción a lo previsto en Partidas, la pena corporal de azotes estaba específicamente prevista para las personas del estado llano; sobre todo de las consideradas viles, y nunca para los hidalgos ${ }^{3}$.

Los azotes no sólo son una pena corporal que llevaba insita una exposición a la vergüenza ante la comunidad, sino que, además, es un castigo duradero pero no necesariamente vitalicio, así como una peculiar forma de marca no

Abreviaturas Empleadas: Sentencias: Arquivo do Reino de Galicia, Serie Sentencias de la Real Audiencia. Crimen: Arquivo do Reino de Galicia, Serie Sala del Crimen. Causas: Arquivo do Reino de Galicia, Serie de Causas, inhibitorias y requerimientos. Gómez: Arquivo do Reino de Galicia, Libros de la Escribanía de Gómez. Fariña: Arquivo do Reino de Galicia, Libros de la Escribanía de Fariña. s: sentencia.

1 Terminaba de forma sarcástica Francisco de QuEvedo su poesía Refiere su vida un embustero de esta manera: «No son de sí los azotes/ tan malos como parecen/pues procesiones los usan/ y los cantan misereres», cito por Antología poética (ed. Pablo Jauralde Pou), Madrid 1993.

${ }^{2}$ GÓmeZ, Antonio: Variae resolutiones Iuris civilis, communis et regii, tomis tribus distinctae, Editio novissima, Cui praeter Annotationes Emanuelis Soarez a Ribeira, acceserunt Ilustrationes, sive Additiones Joannis de Ayllon Laynez in fine cuiusque Capitis appositae, cum Indice generali, Madrid 1794, Tomo III, p. 46, n. 76. Téngase presente lo que al tratar del homicidio manifiesta en Tomo III, cap. 3, p. 136, n. 56 , in fine.

3 «Se puede advertir al Corregidor que a los hombres nobles hidalgos y principales los honre y trate bien, y nunca les ponga penas viles de azotes, galeras, o de ahorcar, assi en los cominatorios, como en las sentencias; ni aun en rebeldia, sino que se informe de su oficio, y constando que son cavalleros, o hidalgos notorios, los trate y condene como a tales: y para esto aun es bien ser los juezes nobles, para que traten bien a los que lo son, porque de ordinario los ignobles, y mal nacidos, son mal intencionados, y hazen lo contrario", en CASTILLO DE BOVADILLA, Jerónimo: Política para corregidores y señores de vasallos, Madrid 1704 (ed. facsímil Madrid 1978), Lib. I, IV, 34, p. 59.

Hispania, LXII/3, núm. 212 (2002) 849-906 
apreciable, a diferencia de lo que sucedía con el corte de orejas o la imposición del hierro candente en algún lugar visible del cuerpo. Además, su consideración jugaba en la posible imposición del tormento ${ }^{4}$, puesto que, los azotes eran una de las formas de ejecutar dicho medio de pruebas.

En Partida 7, 31, 4, al determinar quantas maneras son de pena señalaba que «siete maneras son de penas, porque pueden los judgadores escarmentar a los fazedores de los yerros. E las quatro son delos mayores, e las tres de los menores... La setena es, quando condepnan a alguno que sea açotado, o ferido paladinamente por yerro que fizo, o lo ponen en densonra del...». Hay que destacar la equiparación que se hacía en esta ley de las penas de azotes y vergüenza pública, aun cuando la primera fuera mucho más dura que la segunda, con independencia que ambas conllevaran una sustancial nota de infamia y deshonra.

Antonio de la Peña entendía que los jueces debían fijarla según su albedrío cuando no hubiera pena cierta, por ley o costumbre, pero «advierta mucho el juez que en estas penas que quedan a su albedrío que no sea demasiadamente riguroso, sino con templanza, algunas veces poniendo pena de dineros, otras de vergüenza pública o azotes, si es persona vil y el delito lo requiere» ${ }^{6}$.

Desde la perspectiva jurídico-canónica, Juan Bernardo Díaz de Lugo consideraba que el temor a esta pena corporal tenía una finalidad evidente para los clérigos, para que «cum dolore et citra vitae ac membrorum periculum corrigat» ${ }^{7}$. Podía ser establecida por los jueces eclesiásticos y, a pesar de la prohibición canónica de penas que conllevaran la efusión de sangre, no se incurría en ella si durante la ejecución fluía, ya que era una consecuencia posterior a la sentencia ${ }^{8}$.

4 «Por la fama que contra uno hubiese de haber cometido un delito, es muy discutido si se le puede dar tormento. Conforme a la ley de Partida, por la fama legítimamente probada se puede poner a tormento, con tal que sea un hombre vil y de mala fama o sospechoso de tal delito... Hoy conforme a la ley de Partida ha lugar la pena de tormento en cualquier maleficio y de ello infiere que en el hurto y en los delitos con pena de azotes, ha lugar el tormento», PeÑa, Antonio de la, Tratado muy provechoso, útil y necesario de los jueces y orden de los juicios y penas criminales, texto inserto en LÓPEZ-REY ARRojo, Manuel: Un práctico castellano del siglo XVI. Antonio de la Peña, Madrid 1935, pp. 92-93.

5 Partida 7, 30, 1: «Tormento es vna manera de pena que fallaron los que fueron amadores de la iustiçia para escodriñar e saber la verdad por ello de los malos fechos que se fazen encubierta mente e no pueden ser sabidos ni prouados por otra manera.... E commo quier que las maneras dellos son muchas pero las prinçipales son dos. La vna es fazer con feridas de açotes. La otra es colgando al onbre que quiere tormentar de los braços e cargandole las espaldas de lorigas e las piernas otrosi de lorigas o de otra cosa pesada».

6 PeÑA, Tratado, pp. 68-69.

7 Praxis criminalis canonica, Lugduni 1561, cap. CXXV, Verberari, pp. 298-300.

8 «Et adverte quod iudex ecclesiasticus habet iurisdictionem fustigandi et verberandi, et sententiam suam potest super his mandare executioni absque scrupulo irregularitatis, licet in fustigatione ut in plurimum interveniat aliqualis effusio sanguinis; quia illa qualis qualis effusio non considerat, cum non veniat principaliter ex sententia, sed accidat ex postfacto; et satis est quod in sententia clerici non infert poena ex qua principaliter et inmediate venit sanguinis», Praxis criminalis canonica, p. 299. 
En el siglo XVII Lorenzo Matheu realizó una encendida defensa de la pena de azotes, al advertir que más apartaba al pueblo en la Monarquía hispana dicho castigo, por causa de la ignominia que producía, que el último suplicio: "plus deterret multitudinem popularem Hispanorum, fustigationis poena propter ignominiam resultantem, quam acerba ultimi supplici»?. Es más, acudía a la antigua práctica de la Sala de alcaldes de casa y corte para demostrar su validez, afirmando que la pena de azotes se imponía con mucha frecuencia, y muy raramente la de muerte. Él mismo alega haber consultado los libros de acuerdos entre 1571 y 1600 , advirtiendo que continuamente se utilizaba con hurtadores, ladrones, sediciosos, quebrantadores de cárcel, alcahuetes, lenones, taberneros y tratantes. Además, bastaba con la conminación de esta pena en casos de poca importancia para evitar los delitos más atroces. Por el contrario, en su época la multiplicidad de jurisdicciones había dado al traste con los efectos de esta pena, que parece había decaído en importancia y en su imposición a los delincuentes ${ }^{10}$.

También la Real Audiencia de Mallorca planteó a Felipe V la posibilidad de extender a este reino el castigo de azotes ya que, por privilegio de 11 de agosto de 1430 , no podía imponerse a ninguna persona de cualquier condición, nación o estamento por ningún delito. Sus razonamientos eran que, por tal privilegio:

«se sigue aumentarse los delitos, especialmente de robos, bandos, blasfemias, resistencias de Justicia, y uso de armas cortas, a cuyos delitos han sido siempre muy inclinados los naturales; y sólo podrá refrenarlos y contenerlos el miedo de los azotes, que es castigo a quien tienen más horror, porque el de galeras, presidio

9 Tractatus de re criminali, Madrid 1776, contr. 42, n. 30, p. 238.

10 Tractatus, contr. 42, n. 32, p. 238: «Hac de causa antecessores nostri in Magistru Praefecturae Regis domus, et Curiae, frequentissime hac poena utebantur et perraro poena capitali, vel alia graviori. Quod evidenter apparebit cuicumque Archivii maioris monumenta revolventi. Ego enim libros deliberationis (de acuerdos dicere solemus) scrutavi ab anno millesimo quingentesimo septuagesimo primo, usque ad annum millesimum sexcentesimum, inclusive, et observari, quod usque ad annum millesimum sexcentesimum decimum quintum, poena fustigationis prae manibus, ut ita dicam, continue habebatur, non solum in fures, expilatores, seditiosos, carceris effractores et resistentes familiae; sed in dardanarios, laniones, tabernarios et tractantes in omni genere eduliorum; ita ut in rebus parvi momenti sub comminatione huius poenae pro prima vice absque alia poena liberarentur, et pro secunda poena exequebatur; et tunc raro delicta atrociora perpetrabantur. $\mathrm{Ab}$ eo tempore jurisdictionum privativarum usus increbuit, et punitio condigna delictorum difficilis facta fuit, competentiarum causae multiplicatae, et per indirectum ingulgentiae ianua patefacta, incentivum delinquendi concessum, gliscente audacia exemptorum, et oblivioni commisa primaeva illa severitate. Hinc rerum venalium in foro, macellis, atque tabernis, corruptio, licentia, et abusus; hinc metus poenarum oblitterario, hinc rerum plurimarum confusio. Remedium non solum possible, sed facillimum credo, si jurisdictionum exemptiores de medio tollantur et severitas ad pristinum statum. Neque necessaria erit sanguinis humani profluxio, sed flagellorum poenae ad usum retitutio, sepositis indiscretae miserationis praetextus. Ex universis Hispaniae Regnis, immo et Europae, deteriores ad Curiam tanquam asylum confugiunt et si bene perpendis, ad quod similem poenam potentissimam credo, immo unice efficacem». 
y otros no les hace fuerza, como se experimenta cada día con los reos ausentes, que solicitan componer y ajustar sus delitos, ofreciendo servir en galeras por el tiempo que se les señalare; y sobre este conocimiento discurre la Audiencia, que el único medio que podrá haber, para atajar estos delitos, que por los genios de los naturales y proporción del terreno son muy freqüentes, será el que se execute la pena de azotes, como se ha experimentado en los demás Reynos de esta Corona, despues que se usa de este castigo».

La respuesta de Felipe V, contenida en su Real Resolución de 20 de diciembre de 1717 (Nov. 5, 10, 5) fue estar al estilo del tribunal y a lo dispuesto en su nueva planta, que venía a ratificar las prácticas antiguas de la Audiencia. Los argumentos empleados son muy similares a los defendidos por Matheu: el horror a la pena corporal que dejaba huella física y psicológica en los reos condenados a tal castigo.

Levaggi da cuenta de que en 1785 los alcaldes ordinarios del territorio de la Audiencia de Buenos Aires estaban tan acostumbrados a dictar la pena de azotes que, cuando se les obligó a consultar su imposición a aquella — sin duda por tratarse de una pena corporal - antes de su ejecución, «todos se quejaron, alegando el peligro de su fuga» ${ }^{11}$.

El reinado de Carlos III fue muy complejo en cuanto a regulación de las sanciones penales, ya que si por un lado parece que la práctica judicial había mitigado algunos castigos legales fijados para ciertos delitos, mientras los había endurecido para algunos; por otro, el objetivo de que se cumplieran las disposiciones regias motivó la reiteración del deber, que correspondía a los jueces, de imponer las penas establecidas en la ley sin ningún tipo de variación. En esta línea cabe mencionar, en primer lugar, la Pragmática de 12 de marzo de 1771 (Nov. 12, 40,7) que, entre otras cuestiones, estableció las características para distinguir los delitos no cualificados de aquellos feos y denigrativos. Al mismo tiempo mandaba a jueces y tribunales, «con el mas serio encargo, que á los reos por cuyos delitos, segun la expresion literal ó equivalencia de la razon de las leyes penales del Reyno, corresponda la pena capital, se les imponga esta con toda exâctitud y escrupulosidad, sin declinar al extremo de una nimia indulgencia, ni de una remision arbitraria: declarando como declaro ser mi Real intencion, que no pueda servir de pretexto, ni traerse á conseqüencia para la conmutacion ni minoracion de penas la ley segunda, ni lo prevenido en la ley sexta de este título». Las remisiones citadas en esta disposición lo eran a la conmutación de las penas ordinarias de los delitos por la del servicio de galeras prevista en las Pragmáticas de 25 de noviembre de 1552 y 3 de mayo de 1566; $\mathrm{y}$, a la conmutación de la pena de muerte en servicio de galeras establecida en la Pragmática de 13 de octubre de 1639.

11 LeVAGgl, Abelardo: Manual de Historia del Derecho argentino (Castellano-Indiano/Nacional). Tomo II. Judicial. Civil. Penal, Buenos Aires 1996, pp. 21-22 y 298 
En 1748, dos Reales Ordenes de 16 y 28 de noviembre dispusieron la supresión de la Escuadra de galeras y se determinó los nuevos destinos, completadas con una Orden de 20 de junio de 1749 del marqués de la Ensenada para que a los delincuentes que con anterioridad eran condenados a azotes y galeras, fueran destinados a las minas de Almadén o a los presidios de África ${ }^{12}$. En esta última disposición se determinaba que a los delincuentes que hasta entonces se castigaba con azotes y galeras, en lugar de la pena ordinaria que correspondía a la gravedad y circunstancias de sus delitos, se les enviaría a Almadén; y, «a los reos contraventores de las Pragmaticas y ordenes que prohiven el usso de las armas», y por otros delitos «a quienes se echava a galeras, se les imponga la pena de presidio en uno de los de Africa» ${ }^{13}$.

Por Real Orden de 18 de octubre de 1749 (Nov. 12, 40, 10), con motivo de haberse suprimido la escuadra de galeras - que sin embargo se restablecería en 1784 durante algún tiempo-, se resolvió que los reos condenados a ellas, se les destinase a servir en las minas de Almadén, «y á los de mérito mas leve por gastadores de los presidios de Africa; y que este último castigo se aplicase tambien á aquellos que, aunque merecedores de la pena de minas, no podían se recibidos en ellas, por exceder del número que permite su trabajo; precediendo en unos y otros delinqüentes la vergüenza pública ó azotes». En consecuencia, si consideramos las declaraciones del monarca en estas disposiciones no parece que fuera tan benévola su legislación penal como algunos han querido hacer ver. No obstante, el propio Carlos III sí parece interesado en que los jueces se limiten a cumplir con la ley, la suya claro. Además, A partir de 1748 la situación comienza a simplificarse y homogeneizarse, al convertirse la pena de presidio en la columna de las sanciones penales, especialmente en materia de robos, e incluso va perdiendo importancia lentamente la pena de azotes en estos delitos salvo para aquellos que tuvieran la consideración de calificados.

En la Junta del Reino celebrada en 1775 se dio cuenta de las alteraciones que se estaban verificando en el conocimiento, tramitación y resolución de los casos de corte, decidiéndose el 20 de septiembre que dos licenciados - Vicente Álvarez de Neira y Vicente Tomás Lavandeira - informaran acerca de esta cuestión. El informe que elaboraron fue más allá de lo solicitado, al insertar otras alteraciones en la actuación procedimental de la Audiencia que, en suma, suponía un cambio en el estilo de este tribunal. El discurso de aquellos dos abogados sobre la pena de azotes manifestaba que:

12 Sevilla SOLÁns, Félix: Historia penitenciaria española. La galera, Segovia 1917, pp. 35-37 y 264-265. La Real Orden de 16 de noviembre de 1748 dispuso que no se enviaran «ya en calidad de forzados ni en otro modo, a servir en la escuadra de Galeras los sugetos que (segun hasta aora se ha practicado) merezcan por sus culpas esta pena porque su Real intencion es de que en lugar de ella se les imponga la que equivalga y corresponda a sus delitos».

13 Sevilla, La galera, p. 36. 
«PENA DE AZOTES EN SUMARIO. Tuvo su origen la pena de azotes en la tiranía con los mártires y con los esclavos. Siempre se reputó infame, aunque no falta quien la limite, contra la opinión de muchos, que la tienen por tal, como lo estima el común que, a los que sufren este castigo mira con el maior desprecio, de modo que ya los contempla destituidos de todo honor. Causa porque estos individuos considerándose con el honor perdido, que es el que anima a las acciones heroicas, y detiene para las torpes, caminan sin freno a cometer gravisimos delitos, con la reflexión de que sólo la pena de muerte es la que resta. Esto no necesita más prueba que la de repetidos exemplares y prozesos auténticos con que se justifica.

Sabiamente el autor de La Industria Popular clama contra este castigo y afirma ser perxudicial y deber abolirse por la trascendencia de la ynfamia a las familias de los azotados, opinión que estampada en libro mandado publicar y repartir por el Supremo Senado de la Corona deve detener cuanto se pueda a los jueces y ministros en la ymposición de esta pena, y más con los honrados labradores que en todos tiempos merecieron y merecen la maior atención de los Soberanos, que mirando son los que más sirven al Estado, los estima por aptos para los más relevantes honores en toda carrera.

Rigor parece que una familia que llegó a este tiempo dedicada por su afán a la Agricultura, porque un individuo suio hubiese delinquido se cubra con el negro manto de la ynfamia por una pena que no remedia la maldad si la multiplica. Quando se ve que diestros politicos apoyan castigos que remedian unos daños con beneficio del Estado, y sin perxuicio del honor de los parientes de los culpados.

Cierto es que en el Derecho de los Romanos, en las Leyes o Fuero Real de los Godos, en las de Partida y Recopilación se halla establecida la pena de azotes para ciertos casos; y que, por lo mismo, los Jueces no pueden prescindir de ynponerla, por carecer de facultades para ampliar o restrinxir lo que en ellas se prescribe, ciñéndose al seguro concepto de meros egecutores, no pudiéndose apropiar el de legisladores.

A vista de lo dicho, no dirixo mi dictamen sobre la solicitud de la abolición de esta pena, zerca de lo qual, por lo mesmo que ynsignúa el Autor de La Industria Popular, podemos prometernos que mediará el Real Consejo y resolverá lo más útil. Voto, si, que en la práctica antigua de esta Real Audiencia, acaso no abrá exemplar de haberse condegnado a azotes en Sumario, sino en el caso notorio de rompimiento de cárcel, observando la costumbre que sin principio de derecho se estableció, sin embargo de la repugnancia que tiene semexante castigo por un delito que el Derecho natural disculpa.

Advierto en el dia desatendida la justa costumbre de oir la defensa de los reos y sus pruebas en los casos que la ley prescribe azotes, como aún se hoya antiguamente a los contra quienes se imponía la condenación a presidio en Africa.

Por Derecho natural, divino, Decretos conciliares y canónicos, es hecho ynconcuso que la defensa es de derecho natural y tan constante como que no se hallará viviente sin armas para la defensa. El proceso informativo no sirve para otro efecto que el de asegurar fundamento para la captura. Ya, con los delitos notorios se usa de la equipeya de atar para la sumaria al reo coxido ynfraganti para que le obsten las declaraciones, sin cuyo requisito no sirven para la condenatoria, proposición 
yncontrovertible que se limita únicamente en los delitos de poca consideración y pena leve.

Por tanto, parece que esta nueva práctica no tiene apoyo legal y exige que el Reino clame para que no continúe, a fin de ympedir que sin las formalidades de derecho, se bean afrentadas muchas familias, vien honradas en su esfera, que estimando el honor en el precio que es devido, se ausentan a Payses desconocidos y extraños, como se pudiera ber si se supiesen los nombres de todos los expatriados en Portugal y otros Reinos, daño grave para el Estado.

Los jueces ynferiores procesan y no pocas vezes por motivos particulares, acriminando los delitos los escribanos actuarios, a quienes no faltan pasiones propias, extienden los dichos de la sumaria con más acrimonia de lo que pide el concepto de el que declara, usando de frases que no entiende y toman la confesión y consulta. Sólo con esto o con la pesquisa se ymponen azotes vajo el concepto que lo estanpado y escrito ya es lo cierto, olvidando lo que diariamente sucede y se ve retractados testigos y conbencidos otros por las declaraciones que dicta el procesado. Ympóngase pues esta pena infamatoria en el caso que la Ley la prescrive, pero obsérvese la formalidad en el juicio, oiendo pruebas y defensas del encarcelado, que es en mi sentir lo justo, como el no fiar al pronto el asenso de los prozesos informatibos» 14 .

Si observamos con detenimiento lo expuesto en el pasaje transcrito del Informe jurídico, las cláusulas de quebrantamiento y otra serie de datos complementarios acerca de su imposición, no creo que pueda considerarse la pena de azotes como accesoria de otras ${ }^{15}$, sino impuesta junto con o en composición con ellas. Dentro de la escala punitiva se encuentra por encima o al mismo nivel que otras penas corporales consideradas muy graves, quizás por ese añadido de la pública ignominia a la que se sometía al reo ${ }^{16}$. Creo acertada la afirmación de

${ }^{14}$ Archivo Municipal de La Coruña, Juntas del Reino, Caja 22, Actas de 1775. FernándeZVillamil Alegre, Enrique: Juntas del Reino de Galicia, Madrid 1962, Tomo I, pp. 541 y 548-550. Sólo Álvarez de Neira firmaría el memorial el 15 de octubre de 1775, aceptándolo la Junta del Reino en la conferencia del día siguiente. Como han recogido LAINGUI, André-LeBIGRE, Arlette: Histoire du Droit pénal. I. Le Droit pénal, París, 1979, p. 127, «la fustigation, si elle est bien par excellence une peine corporelle atteignant physiquement les faux témoins, les petits faussaires ou les chapardeurs, elle devait surtout avoir des conséquences morales par le déshoneur qu'elle entraînait».

15 Incluso no llegó a comprender por qué después de citar la vergüenza pública, Francisco TOMÁS Y VALIENTE añadiera que «como accesorias solían imponerse junto a ella las penas de azotes y destierro", en El Derecho penal de la Monarquía absoluta, Madrid 1992, pp. 386-387; pues la ejecución de los azotes en la Corona de Castilla llevaba implícita la vergüenza, ni el destierro creo que tenga la consideración de accesoria de la vergüenza.

16 BAZÁN DIAZ, Iñaki: Delincuencia y criminalidad en el País Vasco en la transición de la Edad Media a la Edad Moderna, Vitoria 1995, p. 580, destaca que los azotes desempeñaron «un doble papel: por un lado fueron complemento de otras penas mayores, como la mutilación, el enclavamiento o el destierro; y por otro, fue un arma de disuasión, es decir, el dolor físico debía ayudar a recapacitar sobre el mal realizado y servir de aviso sobre el futuro». Contrasta que incluya al destierro entre las penas corporales graves cuando más adelante sostiene que el destierro es una pena corporal más, «ocupando el nivel inferior de la escala», p. 584.

Hispania, LXII/3, núm. 212 (2002) 849-906 
Carbasse, según la cual, «la fustigation constituait bien entendu une peine en soi, qui s'est perpétuée jusqu'à la fin de l'Ancien Régime. Le fouet povait être infligé à titre principal, pour des délits bénins, ou en composition avec des peines plus graves» ${ }^{17}$. Ello nos conduce a sostener, a partir de una perspectiva exclusivamente normativa, que no habría una pena principal - galeras o destierro, por ejemplo- y otra accesoria o secundaria - azotes-, ya que se podía pensar que estábamos castigando dos veces por el mismo delito, sino que nos encontraríamos ante una única pena formada o compuesta indisolublemente por dos castigos: galeras o destierro y azotes. Es más, en no pocas ocasiones se emplea la dogmática codificadora penal a los siglos medievales o modernos, con los consiguientes problemas y errores jurídicos, lo cual me lleva a rechazar la consideración de la pena de azotes como accesoria de otras ${ }^{18}$.

Este planteamiento puede conducir a otro. Desconozco hasta qué punto la menor edad pudo jugar en la determinación de los azotes, aunque resulta curioso lo que narraba el conocido pícaro Estebanillo González: «Yo andaba siempre temeroso de que se descubriese la flor, y por cómplice en ella en lugar de enviarme a Galicia me enviaran a Galilea, o por ser muchacho me diesen algún estrecho jubón, no necesitando de él» ${ }^{19}$. Quizás para los menores más que una verdadera pena, los azotes eran un medio de corrección, idea que debió surgir en la Edad Media. En este sentido Laingui y Lebigre sostienen que «le droit laïque moins évolué (que el canónico), se contente de poser le principe de punition comme un axiome avec, peut-être, toutefois un idée de "correction" comme on le dit à propos des enfants - par la souffrance ou par la honte: le fouet ou les mutilations, l'exposition au pilori qui attire la risée publique sur le coupable; peveunt avoir un effet curatif ${ }^{20}$. Quizás nos encontremos con algo interesante en la naturaleza misma de la imposición de los azotes: por un lado, como estamos viendo, era una verdadera pena; pero, por otro, gozó de la consideración de medio correctivo. La diferencia pudiera encontrarse no sólo en el

17 CARBASSE, Jean-Marie: Introduction historique au Droit pénal, París 1990, pp. 230-231.

${ }_{18}$ Por citar un ejemplo, PaLOP RAMOS, José Miguel: «Delitos y penas en la España del siglo XVIII», en Estudis. Revista de Historia Moderna (Valencia) 22 (1996) pp. 65-103, considera las penas corporales no capitales dotadas de «un carácter accesorio o complementario de las de privación de libertad» (p. 93). Ni creo tampoco que pueda afirmarse, como hace dicho historiador, que doscientos azotes fueran "el "plus"» de diez años de presidio africano, «Notas sobre la criminalidad en Galicia a finales del siglo XVIII", en Conflictos y represiones en el Antiguo Régimen, Valencia 2000, pp. 181-208/207.

${ }^{19}$ La vida y hechos de Estebanillo González (ed. de A. Carreira y J.A. Cid), Madrid 1990, Tomo I, p. 57. Sobre las expresiones de la germanía dar jubón, fajar, fajas, aforrar, varear el fardo, entre otras, ALONSO HeRnÁnDeZ, José Luis: El lenguaje de los maleantes españoles de los siglos XVI y XVII: la Germanía, Salamanca 1979, pp. 152, 162 y 187-188. Además, WEBER, Frida: Lo cómico en el teatro de Fernán González de Eslava, Buenos Aires 1963, pp. 165-170.

${ }^{20}$ Histoire du Droit pénal. I. Le droit pénal, pp. 116-117. Además de otras causas de reducción de la pena, los jueces de la Santa Hermandad también condenaron a azotes en supuestos de menor edad, MENDOZa GaRrido, Juan Miguel: Delincuencia y represión en la Castilla Bajomedieval (Los territorios castellano-manchegos), Granada 1999, pp. 477-478.

Hispania, LXII/3, núm. 212 (2002) 849-906 
número de azotes dado — siempre más reducido en la corrección- sino también en el ámbito público o privado en el que nos movamos, puesto que en este segundo supuesto siempre sería correctivo. Como expresa Levaggi, «el número máximo fue de doscientos azotes, porque se consideraba que mayor cantidad era causa de muerte. El mínimo fue de veinticinco, porque hasta esta cifra los azotes no tenían calidad penal sino correccional» ${ }^{21}$.

El empleo de los azotes como medio de corrección puede encontrarse en el castigo de las diferentes modalidades de embriaguez por parte de la justicia ordinaria de la ciudad de México, como ha puesto de manifiesto en un minucioso e interesante estudio Sánchez-Arcilla ${ }^{22}$. Los azotes se aplicaron en especial a las mujeres ebrias ${ }^{23}$, ebrísimas, borrachas, bebidas o que en tal situación realizaran otras conductas sancionadas, sin que faltaran presos corregidos con veinte o veinticinco azotes ${ }^{24}$. Las espaldas de las mujeres que se encontraban ebrias varió entre los ocho y los veinte azotes, siempre en número par, si bien no puede precisar a qué se debe la variación numérica, «tal vez por razones étnicas, pero los datos no permiten asegurarlo con seguridad», aunque también se advierta un endurecimiento a lo largo de los años estudiados ${ }^{25}$. Otro tanto destaca para las mujeres calificadas como borrachas ${ }^{26}$, o para las que se encontraban bebidas ${ }^{27}$. Los veinticinco azotes parece que se consideraba como la pena correctiva agravada y el límite en todos los casos estudiados, con independencia de que los reos sufrieran otra u otras penas, como obras o cárcel por ejemplo, y que aquella, en virtud del arbitrio judicial, se considere adicional o suplementaria de estas, sobre todo cuando concurrieran otras conductas delictivas.

Tampoco puede olvidarse que la imposición de la pena de azotes y la publicidad que conllevaba, junto con la participación activa del pueblo insultando o mofando de cualquier manera al reo, podía ser el resultado de las necesidades de la Corona, expresadas en la sentencia del tribunal juzgador, para manifestar el triunfo de la justicia sobre el delito. Es decir, como los restantes castigos, la

${ }_{21}$ Manual de Historia del Derecho Argentino, II, p. 297, in fine.

22 SÁNCHEZ-ARCILla BERNAL, José: «La Administración de Justicia inferior en la ciudad de México a finales de la época colonial. I. La punición de la embriaguez en los Libros de Reos (17941798)", en Cuadernos de Historia del Derecho (Madrid) 7 (2000) pp. 309-445. Por citar un ejemplo: "Corregidas cada una con 12 azotes, la una por borracha y la otra por ladrona, pónganse en libertad», en p. 399, n. 325; o, «corríjase con 25 azotes a las reas por los desacatos cometidos, y después de tres dias de prición por la embriaguez», p. 422 , n. 481.

23 SÁNCHEZ-ARCILla manifiesta que la pena de azotes era «más propia para los casos de ebriedad femenina», «La punición de la embriaguez», p. 370.

${ }^{24}$ SÁNCHEZ-ARCILlA, «La punición de la embriaguez», p. 370, n. 166, o p. 419, por ejemplo.

25 SÁNCHEZ-ARCILLA, «La punición de la embriaguez», pp. 380-381. Incluso, para las mujeres ebrias «podemos observar que la pena ordinaria durante 1794 era la de veinticinco azotes; sanción que se aplicaba sin tener en cuenta la etnia de la rea».

26 SÁNCHEZ-ARCILLA, "La punición de la embriaguez», pp. 397-398.

27 SÁNCHEZ-ARCILLA, «La punición de la embriaguez», pp. 401-404. 
pena de azotes podía ser la respuesta a las necesidades puntuales o coyunturales de la política criminal del Estado.

\section{2. ÁMBITO DELICTIVO}

Para adentrarnos en su proyección real es conveniente detenerse en el conocimiento de algunas causas judiciales en las cuales los juzgadores impusieron tal castigo, además de enumerar otros supuestos recogidos en la normativa regia. Esta clasificación tiene tan sólo una finalidad expositiva y orientativa.

\subsection{Delitos menores}

Los azotes figuraron como pena para ciertos hechos delictivos que podríamos considerar como menores. Cabe mencionar, por ejemplo, que según el Ordenamiento de Alcalá de 1348 la caza y pesca furtiva se castigaba con cárcel y cadena la primera vez; la segunda se agrava esta pena con azotes; y la tercera se cortaba un miembro. Estos castigos tan duros se vieron rebajados por Pragmáticas de 11 de marzo de 1552 y 17 de noviembre de 1617 a multa, destierro del territorio y pérdida de los instrumentos destinados a la caza o de los aparejos de pesca. No me consta la aplicación del castigo de azotes en tierras gallegas para reprimir el furtivismo.

Otro tanto cabe decir de los escándalos y alborotos provocados en las tomas de posesión de los clérigos y eclesiásticos en Galicia que, según la Real Cédula de 15 de octubre de 1560 (Nov. 12, 12, 9), fueron castigados con cincuenta mil maravedíes y cuatro años de destierro al hijodalgo; y, con doscientos azotes $\mathrm{y}$ dos años de galeras al plebeyo.

Algo similar se estableció para la represión de las máscaras. Si bien no me consta la aplicación, en los territorios gallegos, de las penas previstas por las Cortes de Valladolid de 1523 (N.R. 8, 25, 7. Nov. 12, 13,1) acerca de la prohibición de máscaras, sobre todo por los perjuicios que se ocasionaban y por dar lugar a la comisión o encubrimiento de delitos. Si el incumplidor fuera persona baxa y andara disfrazado de día, se le impondrían públicamente cien azotes, doblados para el supuesto de hacerlo de noche.

La represión de determinadas actividades lúdicas cercanas a conductas que provocaban conflictos personales se extendió a otros comportamientos. Las palabras deshonestas u obscenas por cánticos - las tradicionalmente llamadas pullas-, a tenor de la Pragmática de 15 de junio de 1564 (N.R. 8, 10, 5. Nov. $12,25,6)$ fueron sancionadas con cien azotes y un año de destierro de la ciudad, villa o lugar en el que se cometieren. Con posterioridad, un Bando de 21 de julio de 1803 prohibió en la Corte las palabras obscenas y torpes con otras penas, pero sin llegar a la fustigación. 
Otro espectro penal en el que la pena de azotes se fue abandonando es la vagancia. A propósito de vagos, las Cortes de Madrid de 1435 (N.R. 8, 11, 1 y 2) castigaron con cincuenta o sesenta azotes y expulsión del lugar a los vagos. Por su parte la Pragmática de 25 de noviembre de 1552 , ratificada en este punto por la de 3 de mayo de 1566 (N.R. 8, 11, 6. Nov. 12, 31, 4 y 5) endurecieron este castigo. Por la primera Pragmática, los vagos «que según las leyes destos nuestros Reynos han de ser castigados en pena de azotes, de aquí adelante la dicha pena sea a que sirvan por la primera vez en nuestras galeras quatro años, y sea traido a la vergüenza públicamente, seyendo el tal vagamundo mayor de veinte años; y por la segunda vez le sean dados cien azotes, y sirva en nuestras galeras ocho años; y por la tercera vez le sean dados cien azotes, y sirva perpetuamente en las dichas galeras». Disposiciones posteriores, como la Cédula de 15 de diciembre de 1733 (Nov. 12, 31,6) por el contrario, rebajaron esta dureza y el castigo de la ociosidad giró alrededor del servicio de armas ${ }^{28}$.

En numerosas ocasiones y relacionado con el comportamiento anterior se encuentra el juego. Con sujeción a lo establecido por las Pragmáticas de 2 de febrero de 1568 y 18 de febrero de 1575 (N.R. 8, 26, 15. Nov. 12, 23, 11 y 12) los juegos prohibidos estaban castigados con cinco años de destierro y doscientos ducados, si el reo fuera noble, mientras que al vil con cien azotes, cinco años de galeras y pérdida de bienes. No nos consta que en el territorio del antiguo reino de Galicia durante esta época se impusiera un castigo tan atroz por jugar a los naipes.

\subsection{Delitos mayores}

Existen, sin embargo, ámbitos penales en los que la legislación real fijó de ordinario para su represión los azotes. En concreto, los tratos carnales ilícitos, las blasfemias y otras acciones que infringían los preceptos religiosos, armas prohibidas, las fugas de cárcel y los hurtos. No obstante, en ciertas oportunidades consta su imposición también en casos de concurrencia de delitos: hurtos y abortos ${ }^{29}$. En otras ocasiones no parece que la condena de fustigación estuvie-

${ }^{28}$ Pérez Estévez, Rosa M.: El problema de los vagos en la España del siglo XVIII, Madrid 1976, en particular para la legislación de esta centuria, pp. 169-195.

29 Sentencias, leg. 28525, s. vista de 13 de septiembre de 1611, el fiscal de S.M. con Constanza López, alias Detamón, por la que fue condenada a doscientos azotes y destierro perpetuo del reino, confirmada por la s. de revista de 4 de noviembre de 1611; su pregón: «Hesta es la justicia que el rey nuestro señor manda azer a esta muger por ladrona [encima, famosa] y aber echo muchos partos manda le sean dadas docientas açotes por las calles acostunbradas y sea desterrada deste Reyno perpetuamente y no lo quebrante so pena de muerte quien tal haze que tal pague». Aunque en otro documento: «En la ciudad de la Coruña a quatro dias del mes de nobienbre de mill y seiscientos y honze anos los senores gobernador e oydores deste Reyno que tienen bisto y determinando el pleyto en grado de revista del fiscal de Su Magestad con Costanza Lopez presa, dixeron que la pena de 
ra prevista para el delito enjuiciado, aunque los alcaldes mayores de la Real Audiencia de Galicia decidieran aplicarla al caso juzgado, como sucedió en 1610 en una causa por falso testimonio ${ }^{30}$.

\subsubsection{Tratos carnales ilícitos}

Dentro del ámbito de los tratos carnales ilícitos — que no de la, en mi opinión, mal llamada moral sexual dominante-, la alcahuetería de la esposa fue penada por Pragmática de 18 de febrero de 1575, según la cual los maridos que por precio consintieran que sus mujeres vendieran su cuerpo, «o de otra qualquier manera las induxeren o traxeren a ello, demas de las penas acostumbradas, les sea puesta la misma pena que por leyes de nuestros reynos está puesta a los rufianes ${ }^{31}$, esto es, las penas acostumbradas —azotes con una ristra de ajos, mitra o coroza, plumas untadas con miel, etc-, vergüenza y diez años de galeras por la primera, hasta llegar a los cien azotes y galeras perpetuas la segunda.

La simple alcahuetería o rufianería se castigaba por N.R. 8, 11, 4 de la siguiente manera: a las prostitutas a las que les fuere demostrado que tenían rufián les daban cien azotes «por cada vez que fuere hallado que lo tienen publica o secretamente»; mientras al rufián, otros cien azotes por la primera vez, destierro perpetuo del lugar por la segunda, incluso la pena de muerte a la tercera ocasión. Por su parte la Pragmática de 25 de noviembre de 1552 (N.R. 8, $11,5)$ modificó las penas establecidas para este delito, de manera que castigó a los rufianes con vergüenza y seis años de galeras la primera vez; cien azotes y galeras perpetuas la segunda. Estas últimas penas se agravaron en la Pragmáti-

açotes en que la sobredicha esta condenada no se execute en ella por estar preñada asta que aya parido». Con posterioridad: «Costança Lopez presa en esta carçel real y condenada por Va. Sa. por sentencias de vista y rebista en doçientos açotes y desterrada deste reino y por estar preñada mando Va. SSa. suspender la sentençia hasta que pariese ya mas de quinze dias que parí y aunque en el acuerdo pasado el alcayde de la carçel echo peticion para que Va. SSa. fuese servido mandarme despachar no e sabido lo que en ella se a probeido por ser pobre y estar presa en esta carçel. Suplico a Va. SSa mande despacharme que en ello ara Va. SSa. servicio a Dios y a mi muy gran merced». Sobre la ejecución de penas corporales en mujeres embarazadas, Fuero Real 4, 5, 2.

30 Sentencias, leg. 28582, s. de vista de 5 de febrero de 1610, Nicolás de Costales y Magdalena de Miranda, su mujer, contra Domingo Pérez, pobre, cien azotes y destierro perpetuo; su pregón: «Esta es la justiçia que mandan açer [los señores gobernador e oydores deste reyno, tachado] el Rey nuestro senor por testigo falso mandanle dar duçientos açotes y que sea desterrado de todo este Reyno perpetuamente y no lo quebrante so pena de seis años de galeras y para que a este sea castigo y a otros exenplo y luego se execute en el la sentencia». Aunque en la sentencia eran cien, en el pregón fueron doscientos azotes.

${ }_{31}$ N.R., 8, 20, 9; y, Nov., 12, 27, 3 (con error de data). Al respecto, TOMÁs y VALIENTE, El Derecho penal, pp. 75-76. Téngase presente la prohibición de mancebías públicas dispuesta por Pragmática de 10 de febrero de 1623 , en Nov., 12, 26, 7. 
ca de 3 de mayo de 1556 (Nov.. 12, 27, 1 a 3) al imponerse vergüenza pública y diez años de galeras por la primera, manteniéndose el castigo por la segunda.

Las mancebas de casados y clérigos fueron castigadas a partir de las Cortes de Briviesca de 1387, de Toledo de 1480 y de Madrid de 1502 (N.R. 8, 19, 1. Nov. 12, 26, 3) con un marco de plata y destierro de un año del lugar, la primera vez; marco de plata y destierro de dos años, la segunda; y marco de plata, cien azotes y destierro la tercera. La reiteración de esta medida en sucesivas reuniones de Cortes pone de manifiesto su escaso cumplimiento. No he encontrado autos judiciales en los cuales se decretaran los azotes por esta conducta.

El estupro de doncella noble estaba castigado, en Partida 7, 19,2, con pérdida de la mitad de los bienes, al noble; azotes - sin especificar su número- y destierro a una isla por cinco años, al vil; y, al siervo de casa, pena de muerte ${ }^{32}$. Para Vela y Acuña, en caso de duda sobre la virginidad de la doncella, se creería a esta33. Además, manifestaba que los jueces seculares castellanos imponían a los sentenciados por este hecho la pena del Derecho canónico, reservando para el humilde los azotes y el destierro ${ }^{34}$.

El estupro cometido por criado con sirvientas del señor de la casa en que vivieren a tenor del Ordenamiento de Alcalá, 21, 2 (Nov. 12, 29, 2) estaba castigado con cien azotes. Por su parte el fornicio de criado no hidalgo con mujer, criada o sirvienta de sus amos, lo cual debía ser bastante habitual, se sancionó en la Pragmática de 25 de noviembre de 1565 (Nov. 12, 29,3) con cien azotes y destierro por dos años, y la misma pena se daría a la mujer. No obstante, si estos hechos acaecieran con parienta del señor o amo, doncella que criara en su casa o ama de cría de un hijo se procedería «con más rigor, según la calidad del caso lo requiere».

En el único supuesto que he encontrado en la práctica judicial gallega en que consta haber mediado fuerza, el reo fue castigado en el grado de vista en vergüenza pública y seis años de galeras. El fiscal suplicó, optando los alcaldes mayores de la Audiencia por agravar la pena hasta los doscientos azotes y el citado tiempo al remo ${ }^{35}$, aunque las Partidas penaban esta conducta con la muerte ${ }^{36}$.

32 Partida 7, 19, 2: «E si fuere ome vil, deue ser açotado publicamente, e desterrado en alguna ysla por çinco años. Pero que si fuese sieruo, o siruiente de casa aquel que sosacare o corrompiere alguna de las mugeres sobredichas deue ser quemado por ende».

33 VELA Y ACUÑA, Juan: Tractatus de poenis delictorum, Salamanca 1603, p. 221.

34 VelA, Tractatus, p. 222.

35 Sentencias, leg. 28582, s. de revista de 8 de agosto de 1608, el fiscal de S.M. con Sebastián Fernández Feijoo: «confirmamos la sentençia en este pleyto y causa dada por algunos de los oydores desta Real Audiençia de Su Magestad de que por todas partes fue suplicado con que la berguença publica en que por ella esta condemnado sean duzientos açotes y con esto mandamos que la dicha sentençia se guarde cumpla y execute como en ella se contiene», se le notificó en la cárcel real de Coruña, y en el pregón decía: «Esta hes la justicia que manda hacer [tachado, la Justicia que manda açer] el rei nuestro señor a este honbre por aver estrupado y forzado a una mujer manda le dar ducientos açotes y que sea llevado a las galeras de Su Magestad donde sirba en ellas por tienpo de seis anos en donde sirba al remo y sin sueldo y no lo quebrante en pena de muerte y por que a el sea 
En Partida 7, 17, 15 se dispuso que la mujer que cometiera adulterio y le fuere probado en juicio «debe ser castigada, e ferida publicamente de açotes, e puesta e encerrada en un monasterio de dueñas", además de otras penas ${ }^{37}$. Por su parte, Fuero Real 4, 7, 1 (Nov. 12, 28,1) dispuso que si la mujer casada cometiera adulterio, ella y aquel con quien lo cometió fueran puestos a disposición del marido para que hiciera de ellos lo que quisiera hasta la muerte, aunque desde el siglo XVI, si no antes, esta solución comenzó a entrar en crisis.

Por último, el incesto malicioso mediando matrimonio, fue punido en Partida $7,18,3$ con la pérdida de honra, destierro perpetuo a una isla y confiscación de bienes, en caso de ser noble el reo; pero si el acusado fuera hombre vil, con azotes y destierro perpetuo, en definitiva con muerte civil ${ }^{38}$.

\subsubsection{Delitos contra la religión}

La blasfemia contra Dios, la Virgen o los Santos fue castigada en las Cortes de Briviesca de 1387 con las penas de Partida 7, 28, 2 a 439. Desde las Cortes de Toledo de 1462, Enrique IV dispuso que, además de dichas penas, cualquiera que blasfemara contra Dios o la Virgen, si lo hiciera en la Corte y su rastro, sería castigado con el corte de la lengua y le darían cien azotes públicamente; mientras que si lo hiciera fuera de aquella, se le cortaría la lengua y perdería la mitad de los bienes (N.R. 8, 4, 1 y 2. Nov. 12, 5, 1 y 2). A tenor de lo expuesto, indica Antonio de la Peña que: «De derecho de nuestro reino, tambien hay diversas penas contra los blasfemos y son conforme a la ley de partida... y si

\footnotetext{
castigo y a otros exenplo. Lo quien tal aze que tal pague». Adviértase que actúa únicamente como parte el fiscal, al menos en el grado de revista.

36 Partida 7, 20, 3. Parece, sin embargo, que la práctica común de los tribunales superiores castellanos fue proceder a la conmutación por galeras o presidio, como se efectuó en la sentencia que nos ocupa, aunque agravada con los azotes.

37 Partida 7, 17, 15: «Acusado seyendo algund ome que ouiesse fecho adulterio, si le fuesse prouado que lo fizo, deue morir porende, mas la muger que fiziesse el adulterio maguer le fuesse prouado en juyzio deue ser castigada e ferida publicamente con açotes, e puesta e ençerrada en algund monasterio de dueñas, e demas desto deue perder la dote e las arras que le fueron dadas por razon del casamiento e deuen ser del marido».

38 Partida 7, 18, 3: «Con parienta, o con cuñada faziendo algun ome pecado de luxuria a sabiendas, non se auiendo ayuntado a ella por razon de casamiento, si le fuere prouado en juyzio por testigos, que sean de creer, o por su conosçimiento, deue auer pena de adulterio. Esta mesma pena deue auer la muger que asabiendas fiziere este pecado... e si aquel que fiziesse el casamiento fuere ome vil deuen le dar açotes publicamente, e despues desterrarlo».

39 Partida 7, 28, 4: «Cibdadano, o morador en la villa, o aldea que denostare a Dios, o a Santa Maria por la primera vez pierda la quarta parte de todo lo que ouiere, e por la segunda vez la terçia parte, e por la tercera la meytad, e si de la tercera en adelante lo fiziere sea echado de la tierra. E si fuere otro ome de los menores que no ayan nada, por la primera vez le den cinquenta açotes, por la segunda señalen le con fuego caliente enos beços, que sea fecho a semejança de b. E por la terçera vegada que lo faga, cortenle la lengua».
} 
fuese hombre pobre por la primera vez tiene cincuenta azotes, por la segunda queda señalado con un hierro caliente en los labios y por la tercera vez, le cortan la lengua. Después el rey Don Enrique cuarto, en Toledo año de 1472 y el mismo en Madrid año de 1507 mandó que el que blasfemare en la Corte o dentro de ella y de cinco leguas, le den cien azotes y le corten la lengua y si la cometiere fuera de la Corte, que le corten la lengua y pierda la mitad de sus bienes». Pero inmediatamente después detalla la reducción que se había verificado con carácter general, puesto que la práctica judicial mitigó el castigo más doloroso ${ }^{40}$.

La punición de Partidas, como vemos, se rebajó con posterioridad para quienes renegaran, despecharan u ofendieran de modo semejante a Dios o a la Virgen, salvo para los esclavos que pronunciaran estas palabras, pues en este caso sus dueños podían elegir que le dieran cincuenta azotes según la Pragmática de 22 de julio de 1492 y 2 de febrero de 1502 (N.R. 3, 4, 58. Nov. 12, 5, 4). No obstante, quizás por el frecuente uso de estas palabras, Felipe II en la Pragmática de 3 de mayo de 1566 (N.R. 8, 4, 7. Nov. 12, 5, 7) agravó el castigo dispuesto, ya que a las penas corporales establecidas, les agregó el destino en galeras a quienes blasfemaran o hicieran juramentos por Dios u otros semejantes. Disposiciones posteriores no impidieron el empleo habitual de estas palabras.

Quienes perjuraran por Dios, la Virgen o los santos, según Antonio de la Peña, si lo hicieran con deliberación y «si el perjurio fuese hecho y cometido en daño de alguno, en este caso debe ser castigado por el juez extraordinariamente o en destierro por algún tiempo y aun en este caso podrá el juez al que así se perjuró en daño de la parte, con azotes o con una mitra ponerle en la picota» ${ }^{41}$. A pesar de estar prevista la fustigación, no me consta su imposición por los alcaldes de la Audiencia gallega, aunque las justicias inferiores en causas incoadas por este delito llegaran a castigar con otras penas corporales citadas.

También dentro de las actuaciones delictivas contra la religión cabe mencionar la hechicería. Entre las causas de la Real Audiencia gallega se conservan unos autos por hechicerías sucedidas en la Tierra de Deza, iniciados por la justicia secular ordinaria, relacionadas sobre todo con tratos carnales y sus posibles frutos $^{42}$. Los testigos afirmaron cosas insólitas de la acusada, que al parecer

40 Peña, Tratado, pp. 111-112.

41 PEÑA, Tratado, p. 201.

42 Particulares, leg. 3.621/94, el oficio de la justicia contra Marta de Quián, Domingo de Choren y Simón de Choren. El auto de oficio se dictó el 18 de octubre de 1610 por el juez de Tierra de Deza, porque «a su nota nuebamente hera venido que Marta de Quian vecina de la feligresia de san Cristobal de Canposancos yendo contra nuestra fe catolica azia algunas cosas de suprestiçiones y echiçerias diziendo que aria cosas con que las mugeres no pariesen aunque tubiesen exçeso carnal con los honbres y que aria otras muchas cosas y que con lo que savia aria a un onbre que no bibiese mas de un ano y que no yziese hijos y otras muchas cosas de echiçerias y suprestiçiones contra nuestra santa fee catolica que todo lo qual protesto aberiguar y por estar ocupado en negocios tocantes a la administracion de la justicia cometia la tal averiguacion dello a...» 
tenía fama de saberlas hacer ${ }^{43}$, por lo que fue encarcelada, aunque en su confesión negara saber hacer tales sortilegios ${ }^{44}$.

Dos hermanos, que fueron acusados con la primera, pusieron de manifiesto en su defensa que el auto de oficio no se dirigió contra ellos ni la sumaria información les inculpaba, siendo lo que realizaba la acusada mentira y embuste, y si existiera hechicería, por su ignorancia acerca de ella, pudiera pensarse que la justicia lo habría consentido durante cierto tiempo y que los testigos también trataron con la hechicera o embustera ${ }^{45}$. Por su parte, la acusada negó tener el oficio de «echicera y usar de supresticiones y maleficios», además de solicitar su absolución y la condena en costas a la justicia, al rechazar que fuera verdad la imputación que se la hacía ni poder resumirse por ser mujer honrada y buena cristiana, que jamás uso de aquellos métodos y siempre fue de buena fama ${ }^{46}$.

La justicia ordinaria apercibió a la acusada que no usara «de echiçerias ni enbaucamientos y suprestiçiones y engaños para dar a entender que save dellas», dos años de destierro de la jurisdicción de Deza — bajo la cláusula de quebrantamiento de cien azotes, más cercana a la pena de la ley- y en mil maravedíes; y contra dos de sus clientes, labradores, se dispuso el apercibimien-

${ }^{43}$ La primera testigo dijo que oyó decir que Marta «tiene fama de saver azer cosas de ycheçerias», mencionando algunos hechos asombrosos. Otros cuatro testigos narraron de forma pormenorizada varios sucesos.

44 El 19 de octubre de 1611 dictó auto de prisión, se tomaron nuevas declaraciones a testigos, el 31 de octubre se la tomó confesión en la Torre de Lalín, en la que «niega tener tal oficio de echiçeria ni lo save ni en que manera se haze» y fue preguntada por los casos testificados. El 2 de noviembre hizo comparecer a Simón y Domingo Choren, se les tomó confesión por haber acudido a la citada hechicera y se despachó auto de prisión contra ellos.

${ }^{45}$ En su petición de 3 de noviembre de 1610 se puede leer, que «pues quando fuera verdad lo que dizen los testigos no resulta echiceria alguna ni supresticion sino mentira e ynbuste y cosas que bien mirado se pueden azer naturalmente sin supresticion ni echiço. Lo otro porque quando fuera echicera nosotros no lo supimos como lo supo la Justicia que asta aora lo consentio sin proçeder contra ella y no hes de creher lo ubiera echo ni consentido y ansi nosotros hemos tenido y tenemos justa ynorancia y buena fee y los testigos que algo quisieron declarar contra nosotros de mas de ser nuestros enemigos y bien mirado no dizen cosa de ynportançia, y quando fuera ansi no hera culpa ni delito punible a lo menos en el fuero hesterior lo qual se echa de ver pues si lo fuera procediera Vuestra merced tanbien contra los testigos que declararon aver tratado y comunicado con ella", por lo que solicitaba la absolución.

46 Sostuvo que era «apartada de cometer echicos superticiones encantamientos no usar ninguna harte diabolica ni fraudelenta ni cometido otro ninguno delito", ser de las calidades mencionadas y como tal reputada en toda la comarca, «sin jamas aver avido fama ni rumor de lo en contrario y me sustento y mantengo con mi oficio de costurera y labradora», confesaba y comulgaba en los tiempos instituidos por la Iglesia, sin escándalo en la república y porque de la sumaria no resultaban indicios ni presunciones contra ella, pues «todo lo caluniado hes ynbuste mentira y odio de los testigos de la sumaria», quienes «diponen de oydas de otros terceros sin concluyr en cosa ni berme azer cosa contra la relixion cristiana».

Hispania, LXII/3, núm. 212 (2002) 849-906 
to de que no tuvieran en lo sucesivo comunicación con ella ${ }^{47}$. A tenor de las leyes alfonsinas, parece evidente que no se castigo por hechicería sino por el engaño ${ }^{48}$, de modo que los azotes sólo aparecen mencionados en la cláusula de quebrantamiento y no como pena principal.

Por su parte, Marcos Gutiérrez, con referencia a los adivinos y agoreros, después de reconocer que por Partidas se castigaban con la muerte, pone de manifiesto «que por costumbre de los tribunales se ha conmutado dicha pena de muerte en la de azotes á los hombres, y en la de sacar emplumadas y encorazadas á las mugeres». Lo que justificaba preguntando: «iqué juez por muy íntegro y observante de las leyes que le supongamos, osará hoy levantar dentro de nuestra península un patíbulo para que dé en él su último aliento un mago, un sortílego, un agorero, un adivino?» ${ }^{49}$.

De este modo, por ejemplo, el fiscal de la Real Audiencia de Galicia Vicente Vizcaíno al tratar de los adivinos declaraba que, a pesar de haber sido castigados en algunos casos con la pena de muerte, en su tiempo «por ser una pena tan rigurosa como la de muerte, la ha templado la costumbre de los Tribunales á la de azotes, y ser emplumado y encorozado, que es una de las que señala la Ley» ${ }^{50}$.

\subsubsection{Armas probibidas}

En un ámbito más grave, por las consecuencias que se podían derivar para la vida de las personas, cabe mencionar los supuestos en los cuales mediaban armas prohibidas. Así, la fuerza cometida por un siervo con armas «u otro ye-

47 S. instancia de 22 de diciembre de 1610: «mando y amonesto a la dicha Marta de Quian que no use de echiçerias ni enbaucamientos y suprestiçiones y engaños para dar a entender que save dellas so pena que se proçedera contra ella y sera castigada con todo rigor, y por la culpa que de lo proçesado contra ella resulta la condeno en dos anos de destierro desta merindad y su jurisdiçion el qual salga a cunplir dentro de seis dias despues que fuere suelta de la prision en que hesta y no lo quebrante so pena de çien azotes. Mas la condeno en mil mrs. para la Camara de su Excelencia el Conde de Lemos y de Andrade y a los dichos Domingos y Simon de Choren les mando y amonesto que de aqui adelante no tengan trato ni comunycaçion con la dicha Marta de Quian ni la lleben a sus senbrados y cojetas con aprescebimiento que se proçedera contra ellos y seran castigados con rigor por la mala fama y rumor y escandalo que ay de la dicha cominicacion». Marta de Quián apeló a la Audiencia, admitiéndose el 12 de enero de 1611, pero no se conserva ningún fallo de sus alcaldes mayores.

48 Partida, $7,16,12$, castigado con escarmiento o multa según su arbitrio, apreciando el hombre que hizo el engaño, el que lo recibió, cuál era el engaño y en qué tiempo fue hecho.

49 Marcos Gutiérrez, José: Práctica criminal de España, Madrid 1804, Tomo 3, pp. 22-23, donde se mostró propicio a la derogación de estas disposiciones por inútiles y perjudiciales, proponiendo la indemnización de daños ocasionados como pena correcta, «a no ser que se tuviese algunas veces por conveniente encerrarles en los hospitales de locos».

so VizCAÍnO PÉREZ, Vicente: Codigo y práctica criminal arreglada a las Leyes de España que para direccion de los alcaldes y jueces ordinarios y escribanos reales escribió, Madrid 1797, Tomo II, p. 222. La ley que condenaba a muerte se recogió en Nov. 12, 4, 2.

Hispania, LXII/3, núm. 212 (2002) 849-906 
rro» estaba sancionada en Partida 7, 10, 8 con azotes — sin concretar cantidad-, pudiendo llegar a castigarse hasta con la muerte.

Sin entrar en otras prohibiciones de fabricación, porte y uso, nos interesa detenernos en la Pragmática de 10 de enero de 1687 (Nov. 12, 19, 9), que volvió a reiterar la obligación de observar anteriores leyes y pragmáticas sobre pistolas y armas de fuego cortas, concretándolo en la interdicción de emplearlas en riñas. En aquella norma se disponía la pena de seis años de presidio en África para los nobles y el mismo tiempo en galeras para quienes no lo eran, «sin que los jueces ni tribunales puedan arbitrar en ella, sino es solo executarla» ${ }^{51}$. No obstante, inmediatamente admite la práctica del arbitrio judicial con respecto a los plebeyos, tomando como sanción mínima la anterior y como superior la de galeras y azotes, siempre que conviniera a la administración de justicia y reparo de los daños que se ocasionaban con estas armas.

Las medidas adoptadas para sancionar la tenencia o el uso de armas - de fuego o blancas- no fueron eficaces. La Pragmática de 18 de septiembre de 1758 (Nov. 12, 19, 18) renovó la obligación de imponer las penas previstas para las armas cortas blancas ${ }^{52}$, lo que nos induce a pensar, precisamente, en la falta de cumplimiento y observancia de la prohibición de castigar con penas inferiores a las legalmente establecidas y, en definitiva, que el arbitrio judicial moderó castigos.

Desde una visión práctica, a fines del siglo XVIII se produjo tierras orensanas un enfrentamiento verbal por medio de pullas recíprocas entre dos cuadrillas de jóvenes que degeneró en una reyerta tumultuaria, en la cual los componentes de una de ellas salieron muy mal parados, en concreto uno de los participantes fue apedreado y perdió el ojo izquierdo tras un navajazo ${ }^{53}$. A pesar de las dificultades para determinar la autoría en estas riñas colectivas, en las que todos los intervinientes suelen agredir y recibir golpes, la justicia ordinaria del coto puso en prisión a una de las cuadrillas, cuyos miembros se fugaron en cuanto pudieron para presentarse ante la Sala del Crimen. En la extensísima sentencia que dictó la justicia de Sejalvo fue delimitando la culpa y su corres-

\footnotetext{
51 Esta prohibición de moderar o remitir las penas en cuestiones de armas prohibidas ya estaba recogida en disposiciones anteriores, como en la Pragmática de 27 de octubre de 1663, artículos 2 y 3 (Nov. 12, 19, 8).

52 Se declaraba que «como no han sido enteramente observadas -algunas prohibiciones de uso de armas-, y haciéndose preciso el renovarlas, y que no tengan dispensacion ni conmutacion alguna las penas en ellas impuestas, sino que se pongan en execucion, de modo que produzcan su exemplar el deseado efecto del escarmiento", en Nov., 12, 19, 18. Veáse lo dispuesto sobre los condenados por armas prohibidas y la conmutación de sus penas en la Pragmática de 12 de marzo de 1771 (Nov. 12, 40, 7).

${ }_{53}$ Crimen, leg. 7, 19, el oficio de justicia contra Benito Sierra, Carlos Sierra, Benito Seara, Roque Laje, Andrés Villariño, José Villariño y otros, sobre malos tratamientos hechos a José Sequeiros y otros. El suceso ocurrió a primeros de abril de 1794 en el lugar de Currás, jurisdicción de Villanueva de Rante.
} 
pondiente pena de cada uno de los participantes ${ }^{54}$ : al motor de la quimera, por haber herido con una piedra a un contrincante, haber clavado con un puñal a otro en el ojo izquierdo del que quedó sin vista y haber sido obsceno al bajarse los pantalones ante la dueña de la viña donde acaeció el tumulto, "por lo mismo y por el echo hera acrehedor a que demostrare las espaldas, y se le diesen en ellas doscientos azotes» y en ocho años al presidio de Ferrol; mientras los restantes fueron enviados a este destino, sin previa fustigación, además de ser apercibidos y abonar los gastos de curación y reparación de la cárcel.

La Sala del Crimen, por el contrario, seguramente partiendo de la dificultad de determinar la verdadera culpa de cada uno de los agresores, les destinó por cuatro años a los bajeles de la Armada, sin duda atendiendo a su juventud, lo que para alguno suponía moderación y para otros ablandamiento de la pena, exceptuando al promotor de la riña y autor de las graves heridas ${ }^{55}$. Aquella era

54 Auto de providencia de la justicia de Sejalvo de 27 de julio de 1795: «En el pleito, y causa criminal que ante mi ha pendido, y pende del Muy Noble y Real Oficio de Justizia que administro contra las personas de Benito y Carlos Sierra, Benito Seara, Roque Laxe, Andres, y Josef Villarino reos que por aver en ronpido la carzel y prisiones se hallan ausentes, como tambien lo estan Miguel Casas, Josef Carvallal, Josef Martinez, y Josef menor que este se halla presente y escarzerado vajo fianza de estar a juicio, juzgado y sentenciado. De la una parte; Que contra el y los predichos se procedio en reveldia, y por ellos en los extrados de esta Audiencia se sustancio la causa en reveldia y contra el predicho menor por haverse apartado, como acusados por proceder en a manera de tumulto y haver en dado muchos golpes hiriendo con piedras a Domingo, y Josef Fernandez Josef y Juan Sequeiros, Lazaro de Novoa, y ansi mismo a otro llamado Josef Fernandez en el dia dos del mes de Abril del año pasado de mil setecientos noventa y quatro segun se vee y consta de la sumaria, ratificacion, escritura de compromiso, provanza fiscal por donde consta ser en tales reos como lo justifica de la otra parte Miguel Gutierrez promotor fiscal nombrado para la acusaçion de los delinquentes, y por ynçidençia, y secuela de lo ynicial el ronpimiento de la carzel y prisiones echo el dia veinte y tres de Junio del mismo año proxsimo pasado por Benito y Carlos Sierra, Benito Seara, Roque Laje, Andres y Josef Villarino... contra quienes es devida la providencia asi por el mencionado delito como por lo mas efectivamente provado y contenido en autos; Que con la submision y consulta a la Sala me preziça y debo hacer al Sor. Presidente... Fallo atento los meritos del prozeso a que en lo nezesario me refiero que por lo que contra los sobre dichos resulta debo de mandar y mando condenar y condeno en primero lugar a Benito Sierra motor de la quimera haver herido con una piedra en la caveza a Domingo Fernandez haver clavado con un puñal a Josef Sequeiros el ojo yzquierdo del qual quedo sin vista, haverse demostrado tan obsceno, yndezente con tanta divertinaje vajandose los calzones demostrandose el trasero a la Da. Maria Francisca Sanchez, y circunstantes, por lo mismo y por el echo hera acrehedor a que demostrare las espaldas, y se le diesen en ellas doscientos azotes en la forma ordinaria, lo que dejo a la consideracion de la Sala, como tanbien lo hago de la graduacion y falta de la vista del ojo de Josef Sequeiros, y por aora le destino por espacio de ôcho anos al presidio del Ferrol, y en el sirva a S.M. o ya de operario para todos los destinos de aquel Arsenal o ya particular en la fabrica de Garcia. En segundo lugar condeno a Josef Villarino como sujeto que se manejava con dos cuchillos, o puñales al mismo presidio por seis años con la misma aplicazion. En tercero lugar condeno a Roque Laje, Miguel Casas, Josef Carvallal, Josef Menor, Andres Villarino, Josef Martinez, Benito Seara, y Carlos Sierra, por quatro años al mismo presidio».

ss S. de la Sala del Crimen 18 de noviembre de 1796: «rebocamos la sentencia del ynferior y en su consequencia destinamos a Joseph y Andres Vilariño, Roque de Lage, Miguel Casas, Joseph 
una pena más leve que el límite superior previsto en las disposiciones reales para las riñas casuales, ya citado ${ }^{56}$ y, también los cien azotes con que se castigaban las pullas y cantares deshonestos, de lo que ya he dejado constancia ${ }^{57}$.

\subsubsection{Resistencia a la justicia y fugas de cárcel.}

De otro lado, no todos los supuestos de resistencia a la justicia estaban castigados con la pena de azotes. El Ordenamiento de Alcalá, 20, 13 (Nov. 12, $10,4)$ castigaba a quienes acometieran a los oficiales de justicia, con o sin armas, con el fin de herir, matar o deshonrar con multa y destierro del reino, si el acusado fuera hidalgo u hombre honrado; con un año de cadena y destierro por dos años del reino, en caso de ser plebeyo no honrado - bombre de menor guisa-; y, cincuenta azotes y un año de cárcel si se tratara de un vago - bombre baldío, en expresión de esta ley-. Por su parte, la Pragmática de mayo de 1566 determinó que las resistencias a las justicias reales que debieran ser castigadas con pena corporal, ésta se conmutara por vergüenza y ocho años de galeras, "salvo si la resistencia fuere tan calificada que para el exemplo de la justicia se deva y convenga hazer mayor castigo". En este último inciso encajaría la condena impuesta a tres vecinos de la jurisdicción de Monfero, quienes junto a otros habitantes de la misma se debieron oponer al cumplimiento de ciertas sentencias a favor del monasterio, por lo que debió intervenir uno de los alcaldes mayores de la Audiencia. La fuerte resistencia — calificada - motivó la imposición de ocho años de destino marino y doscientos azotes a los tres acusados, lo que les obligó a huir de la justicia ${ }^{58}$.

Otro de los hechos delictivos donde con mayor frecuencia se aplicaron los azotes fue la fuga de la cárcel. Cuando un preso quebrantara la prisión en que se hallare, además de ser tenido como autor del delito por el cual se encontraba

\footnotetext{
Carballal, Joseph Menor, Joseph Martinez, Benito Seara, y Carlos Sierra, a cada uno por quatro años a los Reales Baxeles».

56 Pragmática de 12 de marzo de 1771 (Nov. 12, 40, 7), castigadas con presidios de África por tiempo no superior a diez años.

57 Pragmática de 15 de julio de 1564 (N.R. 8, 10, 5. Nov. 12, 25, 6).

58 Sentencias, leg. 28541, s. vista de 19 de septiembre de 1704, el fiscal de S.M. con Bartolomé Morado, María López y una larga lista de consortes, a que salieron Antonio Sanjurjo Montenegro, delator en esta causa, y el abad y monasterio de Monfero: "confirmamos la sentencia en esta causa dada por el señor Dn Alonso Balbuena del Consejo de Su Magestad y su oydor en esta Real Audiencia pronunciada en treinta y uno de março del año pasado de mil sietecientos y tres de que por el fiscal de Su Magestad en este reino para ante nos fue apelado y aciendo justicia condegnamos, a los dichos Bartolome Morado, Amaro dos Caniços.... y se les apercive a los dichos reos que adelante respeten y veneren con toda atencion a la justicia y sus menistros pena de diez años de destierro en los presidios de Africa, Y a los dichos Joachin da Fraga, Lucas Paz y Andres Morado, les condenamos en ducientas azotes y ocho años de galeras». La s. de revista de 12 de diciembre de 1704 confirmó la anterior en todos sus términos.
} 
encarcelado; o, cuando todos los delincuentes que se hallaran en prisión lograran rompen las prisiones o intentaran fugarse, sin mediar caso pensado y comunicado, Villadiego defiende que «aun en tal caso no se les ha de dar la pena ordinaria, como a verdaderos hechores del delito, sino menor: y lo ordinario es azotes, por la fuga, y quebrantamiento de la Carcel, quando la causa de la prision es grave, y justificada» 59 .

Diego Pérez de Salamanca, al comentar la correspondiente ley del Ordenamiento Real, con remisión a Partida 7, 29, 13, entendía que la pena del efractor de cárcel era arbitraria, fundamentalmente azotes ${ }^{60}$. Por su parte, Antonio de la Peña daba cuenta que siendo juez «tuve este caso en plática, que teniendo un hombre preso quebró una cadena y se escapó, por lo que fue traído a la vergüenza y otros son por ello azotados o condenados en seiscientos maravedises para la cámara de su majestad; según la calidad del delito y de la persona y en estas cosas que se dejan al albedrío del juez, muy bueno es que los jueces se moderen pues mejor será que dé cuenta por haber usado de misericordia que no por haber sido cruel» ${ }^{61}$.

Durante el siglo XVI los azotes también sirvieron para castigar a los presos por los alborotos, de diversa índole, que originaban en la cárcel. Testimonios de su aplicación en la cárcel de Sevilla dan cuenta de su ejecución por las calles acostumbradas de la ciudad, aun cuando lo habitual fue su aplicación en el patio de aquel recinto ${ }^{62}$.

En 1706 hubo un intento de fuga - querer escaparse- de la cárcel real de Coruña por algunos presos condenados a galeras. Los alcaldes mayores reaccionaron castigando a todos ellos en doscientos azotes y a los que ya estaban condenados se les penó con diez años a galeras y la obligación de obtener la licencia regia para poder salir de ellas ${ }^{63}$. Hay que tener presente que era una fuga

59 VIlladiego DE VASCUÑANA Y MONTOYA, Alonso de: Instrucción política y práctica judicial, Madrid, 1720 , p. 200 , n. 19. Completa la afirmación anterior, al sostener que «esto se entiende, quando se salieron sobre caso pensado, y comunicado entre todos los presos, o muchos dellos, rompiendo las paredes, y prisiones; que en tal caso serán avidos por hechores del delito, y deben ser castigados cada uno en la pena que merece su culpa, y delito; pero si de otra manera se salió el preso, debe ser castigado arbitrariamente. Y lo ordinario es en pena de azotes por la efractura», p. 201, n. 25.

60 Pérez de SalamanCA, Diego: Commentaria in Ordinationes Regias Castellae, Salamanca 1609, glosa «Fuyere de la cadena, vaya por fechor» de la ley 34, tit. 19, libro 8: «fragendo carcerem poena pro fractione est arbitraria et punitur violator carceris, ipsum flagellis cedendo, vel alia poena ad arbitrium iudicis... et est practica communiter recepta, quae colligitur ex dicta 1.13 ad fin, titulo 29, part. septima».

61 Tratado, pp. 168-169.

62 Los datos en Herrera PugA, Pedro: Sociedad y delincuencia en el Siglo de Oro, Sevilla 1974, pp. $172-173$ y 176.

63 Sentencias, leg. 28541, s. de vista de 20 de octubre de 1706, el oficio de justicia con Roque Galiano, Eufrasio de Rivera, Alonso Merino, Juan Medelo, Antonio Fernández, Jacinto Carvallo, todos presos en la cárcel real: "condenamos a los dichos Roque Galiano, Eufraçio de Ribera, Alonso Merino, Juan Medelo, Antonio Fernandez y Jaçinto Carvallo, cada uno en duçientos açotes para lo 
numerosa y en la cárcel inmediatamente dependiente de la Audiencia. Esta solución también fue adoptada en la misma centuria por la Real Audiencia de Sevilla ${ }^{64}$.

Mediado el siglo XVIII Berni recogía sobre este asunto la práctica derivada del arbitrio judicial de imponer doscientos azotes a los fugitivos de la cárcel: «La L. 13, tit. 29, part. 7 previene, que el reo quebrantador de carcel, es havido por confesso del delito, porque está preso, y otras penas al arbitrio del juez, que se reducen a 200 azotes o verguenza publica segun la practica de oy» ${ }^{65}$.

Un Auto de la Sala de alcaldes de Casa y Corte de 29 de octubre de 1785 (Nov. 12, 38, 3, nota), dictado con motivo de cierta causa formada contra algunos presos de la cárcel sobre diferentes excesos y preparativos para fugarse, mandó que, a fin de evitar tales desórdenes, los alcaides pusieran a los jóvenes con separación de los demás presos, «y que por voz de pregonero, se publicará, que á qualquiera, que incurra en semejantes excesos de livianidad, se le impondrá la pena de doscienos azotes, y siendo noble, quatro años de presidio, ú otra grave á arbitrio de la Sala». Sin entrar en la aplicación de este castigo, no todas las causas consultadas en las que se produjo fuga se penaron con azotes.

\subsubsection{Hurtos}

A pesar de todos los supuestos detallados, la pena de azotes se empleó, fundamentalmente, en el castigo de los hurtos, donde aparece como una de las

qual sean sacados de la carçel real donde se allan en bestias de albarda por las calles publicas con boz de pregonero que publique su delito; $\mathrm{Y}$ asimesmo a los que estan condenados y rematados en diez años de galeras se les condena en que no salgan dellas sin espresa horden de Su Magestad, y a los condenados a galeras en menos de los diez años se les condena en ellas y a que los sirvan enteros y cunplidos y no salgan dellas sin la misma orden de Su Magestad»; y, en Gómez, Libro 60, Letra Fiscal, f. 320 v., el fiscal de S.M. con Roque Galiano y otros presos de la carcel real «sobre querer escaparse». Este Jacinto Carvallo puede ser el que años más tarde por Sentencias, leg. 28545, s. de vista de 16 de octubre de 1716, fue enviado seis años al azogue, por ladrón cuatrero y castigado con doscientos azotes que se le dieron el mismo día, para lo cual el escribano fue a buscarlo a la cárcel real, de donde salio «caballero en bestia de albarda, atado de pies y manos, con pie de amigo al pescuezo y el executor de la justicia le llevo por las calles publicas y acostumbradas de esta ciudad y su Pescaderia, y a las esquinas publicó su delito diciendo: esta es la justicia que el Rey, nuestro Señor, manda hacer en este hombre por ladron quatrero y condenado en duzientos azotes y en seis años en las minas del azogue. Y executó la dicha sentencia de azotes».

${ }^{64}$ Fundamentos que tuvieron presentes los alcaldes del crimen de su magestad en la Real Audiencia de Sevilla, quando debolvieron a los juezes ordinarios para su execucion, la Providencia que consultaron a la Sala, del castigo, o escarmiento de azotes en diferentes reos por la fuga de carcel, manifestados al publico por un dependiente e interesado en el honor de la Sala, s.l., s.f. (circa 1724).

65 BERNI, Joseph: Apuntamientos sobre las Leyes de Partida al tenor de las Leyes Recopiladas, autos acordados, autores españoles, y practica moderna, Madrid 1759, p. 109. 
sanciones punitivas más habituales ${ }^{66}$. En consecuencia se puede afirmar, sin temor a equívoco, que el ámbito criminal en el cual más se castigó con la pena de azotes fue, sin lugar a dudas, el hurto. El ordenamiento regio así lo recogía y la práctica de los tribunales reales da cuenta de ello, aunque quizá no en la medida prevista por aquel.

Con relación al hurto ${ }^{67}$, las penas que se recogieron en las Partidas debieron de atemperarse con el transcurso del tiempo y la toma en consideración de otras situaciones — quizás auspiciadas por nuevas circunstancias socioeconómicas-. Las autoridades judiciales de la Corona castellana debieron moderar las puniciones alfonsinas, lo que al parecer conllevó, a su vez, un aumento de la criminalidad. De nuevo concurrirían con visiones diferentes las sanciones legalmente establecidas para reprimir los hurtos y la realidad de unas sentencias con penas moderadas ${ }^{68}$.

La disposición más interesante dentro de este ámbito se encuentra en Partida $7,14,18$, puesto que en esta ley se determina la pena que merecen quienes hurtan y roban: de pecho o con escarmiento en el cuerpo. Después de distinguir entre las penas que corresponden al hurto manifiesto y al no manifiesto establece: «deven los judgadores quando les fuere demandado en juyzio, escarmentar los furtadores publicamente con feridas de açotes, o de otra guisa, de manera que sufran pena, e verguença. Mas por razon de furto non deve matar, ni cortar miembro ninguno». Aunque la propia ley agrava la pena para ciertos ladrones.

El punto de inflexión en la regulación de los hurtos se produjo con las reformas de Felipe II introducidas en las Pragmáticas de 25 de noviembre de 1552 (N.R. 8, 11, 7. Nov. 12, 14, 1) y 3 de mayo de 1566. Por aquella se había establecido que los ladrones que cometieran sus hurtos fuera de la Corte y que conforme a la legislación del reino debieran ser castigados con azotes, «de aqui adelante la pena sea, que le traygan a la verguença publica y que sirva quatro años en nuestras galeras por la primera vez, siendo el tal ladron mayor de veinte años, y por la segunda, le den cien açotes y sirva perpetuamente en

\footnotetext{
${ }^{66}$ A la misma conclusión llega MENDOZa GARRIDO, Delincuencia y represión, pp. 473-489, al estudiar la actuación de la Santa Hermandad en el tránsito del siglo XV al XVI.

67 PeredA, J: «El hurto famélico o necesario», en Anuario de Derecho Penal (Madrid) 17 (1964) pp. 5-28; y, «Famosus latro», en Anuario de Derecho Penal (Madrid) 16 (1962) pp. 5-22. RoDriguEZ MOURULLO, Gonzalo: «La distinción hurto-robo en el Derecho histórico español», en A.H.D.E. (Madrid) 32 (1962) pp. 25-111, aunque discrepo que en la época aquí estudiada sea factible desentrañar con rigor tal distinción. SAINZ GUERRA, Juan: «Hurtadores, ladrones, descuideros y robadores», Actas de las III Jornadas de Historia del Derecho. La aplicación del Derecho a lo largo de la Historia, Jaén 1997, pp. 95-128.

68 Pragmática de 3 de mayo de 1566 (Nov. 12, 14, 2), cuyo tenor no deja lugar a dudas: «y como quiera que, conforme al uso y estilo que los jueces tienen en estos reynos, en el dicho caso del primer hurto condenan en setenas, y en su defecto en la dicha pena de azotes; ordenamos y queremos, que la dicha condenacion de galeras sea precisa, y no en defecto de setenas».
} 
las dichas galeras» ${ }^{69}$. Además, el ámbito personal de esta ley se completaba con otra mención expresa, pues «los ladrones y vagamundos y holgazanes menores de la dicha edad de veynte años, y las mugeres vagamundas, y ladronas, y los esclavos de qualquier edad que sean.los susodichos, siendo presos por los susodicho, no sean echados a las galeras, sino penados y castigados conforme a las leyes de nuestros Reynos», de donde resulta destacable la equiparación, al menos en el nivel de teoría normativa, entre menores de edad y mujeres, y la obligación de imponerles pena diferente a la de galeras, aunque nada dice con respecto a los azotes y vergüenza en que sí podían llegar a ser castigados. Mientras que en 1566 se agravó la dureza, al aumentar en los mismos casos la duración de la pena de galeras a seis años, siendo por lo menos mayores de 17 años. Con ello, por el primer hurto cometido por mayor de 17 fuera de la Corte se condenaba a vergüenza pública y seis años de galeras, por el segundo a cien azotes y galeras perpetuas, y por el tercero se imponía la pena capital ${ }^{70}$.

No todos los hurtos, sin embargo, tenían la misma consideración, por lo que era muy difícil aplicarles por igual los castigos establecidos en la normativa regia. Los intentos reales para que las penas legales destinadas a reprimir los hurtos se cumplieran no se debieron de respetar por jueces y tribunales. La famosa Pragmática de 23 de febrero de 1734 nos vuelve a poner de manifiesto implícitamente dicha falta de observancia y los consiguientes problemas de aumento de la criminalidad ${ }^{71}$.

Por virtud de tal disposición, Felipe $\mathrm{V}$ agravó las penas impuestas para los hurtos cometidos en la Corte y sus alrededores, a pesar de que la aludida benignidad judicial no sólo se daba en ella sino en otros lugares muy distantes. Para todos aquellos mayores de 17 años a los que fuere probado haber robado en la Corte o su rastro, entrando en casas, cometiéndolo en calles o caminos, con armas o sin ellas, solo o acompañado, con independencia de que se provocara herida o muerte, se le impondría la pena capital; y si no llegara a tal edad, pero excediere de los 15 años, le castigarían a doscientos azotes y diez años de

${ }^{69}$ Esta Pragmática de noviembre de 1552 determinó que si sucediera en la Corte, la primera vez cien azotes y ocho años, y la segunda doscientos azotes y galeras perpetuas.

${ }^{70}$ N.R. 8, 11, 9 (Nov. 12, 14, 2). Pero se ha de tener presente la posibilidad de conmutación prevista en las Pragmáticas de 25 de noviembre de 1552 y 3 de mayo de 1566 (N.R. 8, 11, 8. Nov. $12,40,2)$, al permitir que en los hurtos calificados, robos, asaltos en caminos o despoblado y fuerzas, no siendo delitos tan calificados y graves a la República que conviniera no diferir su ejecución, en que buenamente pudiera haber lugar a la conmutación, sin perjuicio de los querellantes, las penas ordinarias podían ser conmutadas por galeras y por el tiempo que les pareciera a los juzgadores, según la calidad de los delitos.

71 «Reconociendo con lastimosa experiencia la reiteracion con que se cometen en mi Corte y caminos inmediatos y públicos de ella los delitos de hurto y violencias; enterado de que igual desenfreno puede motivarse de la benignidad con que se ha practicado lo dispuesto por algunas leyes del reyno, sin embargo de lo prevenido por otras anteriores, que condignamente imponen la mayor pena para su castigo y escarmiento..." A.A. 8, 11, 19 (Nov. 12, 14, 3). Véase los comentarios a la misma de TOMÁs y VALIENTE, El Derecho penal, pp. 253-254.

Hispania, LXII/3, núm. 212 (2002) 849-906 
galeras. Igual castigo se impondría a quienes receptaran o encubrieran maliciosamente algunos de los bienes robados; como también a quienes no consumaran el hurto. Esta Pragmática, sin embargo, planteó algunos problemas de interpretación que se trataron de resolver en otra de 3 de noviembre de 1735, con el fin de evitar que el arbitrio judicial, movido por compasión o benignidad, rebajara las penas dispuestas en la normativa real ${ }^{72}$.

En este sentido, la Sala de alcaldes de Casa y Corte consultó al monarca la posibilidad de rebajar, manteniendo la Pragmática de 1734 y su declaratoria de 1735 , las penas en ellas establecidas para los hurtos simples por su menor importancia y trascendencia ${ }^{73}$, en atención a la desorbitada proporcionalidad entre el hecho delictivo cometido y la pena con que se sancionaba. Estas apreciaciones fueron resueltas por consultas de 9 de abril y 23 de noviembre de 1745 (Nov. $12,14,6)$, declarando expresamente el empleo del arbitrio judicial: «he resuelto, que las penas de los hurtos simples sean arbitrarias, segun y como la Sala regulare la qualidad del hurto, teniendo presente para ello la repiticion ó reincidencia, el valor de lo que se regulare del robo, la calidad de la persona á quien se robó, y la del delinqüente, con lo demas que se halla prevenido por el Derecho». Además, hay que tener presente la Real Orden de 18 de abril de 1746.

Vizcaíno Pérez, fundado en estas y otras disposiciones regias, clasificaba los hurtos de la siguiente manera:

- hurtos simples, castigados con la pena que determinara el arbitrio judicial «regulando las circunstancias que concurran». De acuerdo con la Real Orden de 18 de abril de 1746 quedaban modificadas Partida 7, 14,18 y N.R. $8,11,7$ y 9 , de modo que el primer y segundo hurto ya no serían castigados con la pena de azotes y galeras, sino quedaba arbitrio del juez «para que la impongan segun las circunstancias del ladron, persona robada, y mas qualidades, atendiendo el primero y segundo». Lo que no fijaron estas normas reales fue el castigo por el tercer y sucesivos hurtos, cuestión ampliamente debatida ${ }^{74}$, inclinándose Vizcaíno

72 A.A. 8, 11, 21 (Nov. 12, 14, 5). Disposición de la que cabe resaltar el siguiente pasaje: «fuí servido declarar que todo hurto, calificado ó no, de poca ó mucha cantidad, debe estar sujeto á la pena de la pragmatica... Y porque puede pretextarse por motivo de no hacerse justicia en la especie de causas de hurtos, robos y latrocinios, comprehendidas en las penas de la citada pragmática, segun sus expresiones y mi Real intencion, las dilaciones que se suelen interponer por parte de los reos, ó las que dicta una mal entendida compasion para preservarlos, ó la malicia de los Ministros inferiores que manejan las causas".

73 «Los simples de corta cantidad sin violencia ó fuerza... o que el robo llegase á la cantidad que fuese de mi Real agrado", en Nov. 12, 14, 6.

${ }^{74}$ A la vista de la Real Orden de 18 de abril de 1746, «de esta orden y citadas Leyes deducimos legitimamente, que los hurtos simples tienen la pena que al juez le parezca imponerle por su prudente arbitrio, regulando las circunstancias que concurran en el hurto. Por esta Real orden se ven enmendadas las citadas Leyes 7 y 9 del tit. 11, lib. 8 de la Recop., y aun la Ley 18, tit. 14 de la Partida 7, por las quales se les imponia por el primero y segundo hurto la pena de azotes y galeras, 
porque no llegara el arbitrio hasta la pena capital pero entendiendo que los jueces sí podrían agravarla hasta donde les pareciera justo segun la condicion del ladrón, cualidades de las víctimas, valor del hurto «y más circunstancias" ${ }^{75}$

- hurto cualificado, dirá Vizcaíno, «es aquel que tiene anexa alguna qualidad agravante dentro de la misma especie, ó declarado de qualificado expresamente por la Ley, lo qual manifiesta mayor malicia y meditada intencion de ofender al próximo y quebrantar la Ley del Soberano, como el hurto de cosa sagrada ó en la Iglesia, el robo en público camino ó en gavilla». Esta cualificación podía derivar de la ley y de su especial gravedad, o de aquella y de otros justos motivos que por conveniencia llevaron a ello. Estos estaban castigados con la pena de muerte natural ${ }^{76}$.

Alvarez Posadilla aporta un testimonio transcendental acerca de las reglas que sirvieron para fundamentar las sentencias en las cuales se imponía a los ladrones doscientos azotes y diez años de presidio, pues la pena del hurto calificado no debería ser inferior a la del simple y como, además, la estancia en presidio no podía ser perpetua, la práctica optó por imponer a los villanos el mencionado castigo. En este sentido, en virtud de las reglas de conmutación, un robo calificado que por leyes anteriores a la Pragmática de 1566 era castigado con la muerte, se conmutaría por cien azotes y galeras perpetuas, o presidio - que si bien en principio era perpetuo, después se convirtió en temporal-. Al preguntar el discípulo si serían entonces azotes y diez años de presidio, responde:

«eso es lo de menos; pero no hay duda que el juez puede imponer la de doscientos; la razon, la pena de cien azotes, y galeras perpetuas, imponen las Leyes citadas 7 y 9, a los hurtos de segunda vez no calificados, sin que jamas hayan llegado las penas de ellos á la capital. La Ley 8 quando conmuta la capital de los delitos, en general dice á galeras por el tiempo segun la qualidad de los delitos; es constante que no haya de ser la pena menor del delito que es capital á la del que no lo es, y supuesto de que es mayor, podrá muy bien, y deberá ser mayor; no lo puede ser en los años de galeras, ni de presidio, con que lo deberá ser en los azotes, y mas despues de que los presidios no pueden ser perpetuos, y así conmumente los jueces á los ladrones de los delitos calificados que destinase á presidio

pues hoy queda al arbitrio del juez el moderar esta pena. La duda que dexa esta última Real Resolucion - 13 de abril de 1764- y citadas Leyes, es, que imponiendo esta determinada pena al ladron por el primero y segundo hurto, y dexándolos aquella al prudente arbitrio de los jueces para que la impongan segun las circunstancias del ladron, persona robada, y mas qualidades, atendiendo el primero y segundo, ¿qué pena le corresponderá al ladron por el tercero, quarto y mas hurtos simples, y si podrán los jueces imponerles segun su arbitrio hasta la pena de muerte... yo firmemente opino muy al contrario, y que por ninguna ley, motivo, ni razón pueden los jueces extender la pena arbitraria señalada por los hurtos simples hasta la capital», en VizCAínO, Código, pp. 310-312.

75 VizCAíno, Código, pp. 312-316.

76 Vizcaíno, Código, pp. 318-319. 
en virtud de la conmutacion de la Ley 8 con arreglo á estas doctrinas les condenan en la pena de doscientos azotes (se entiende quando los reos no son nobles) ademas de él presidio ó galeras, hoy ya se mandan destinar á las galeras, por orden posterior».

\section{Completa su criterio para la fijación del número de azotes al sostener que:}

«las Leyes de la Recopilación para los hurtos calificados, quando estos tenian la pena capital, siendo de segundo hurto, ademas de las galeras perpetuas, mandan se les den cien azotes, con que en los cien azotes no tiene arbitrio los jueces á minorar; pero como el delito calificado las Leyes han querido castigar, y ademas las galeras perpetuas hayan quedado en diez años, me parece que el juez, (y así comunmente se hace) debe estender la pena de los cien azotes que no pudo rebaxar por señalarla la Ley á los hurtos que nunca se castigaron con pena capital, á doscientos, ademas de los diez años de presidio ó galeras»77.

La conclusión lleva a defender que la pena arbitraria de los hurtos calificados y penados con la muerte, en opinión de Alvarez Posadilla, debería ser por vía de conmutación al menos igual o superior a la pena del segundo hurto simple, pudiendo arbitrar el juez tan sólo en el aumento de los azotes hasta doscientos ${ }^{78}$.

La práctica totalidad de los casos en que la Audiencia gallega decretó la pena de azotes lo fueron causas por robos de diferente naturaleza, bien fueran cometidos por simples ladrones ${ }^{79}$ o por otros considerados como famosos ${ }^{80}$. En ocasiones eran de singular relevancia por lo hurtado, como en los sacrílegos ${ }^{81}$.

77 Álvarez Posadilla, Práctica, Tomo III, pp. 409-410.

78 Álvarez Posadilla, Práctica, Tomo III, pp. 411-412, al tratar de la conmutación de penas: «Por conclusión sacamos que segun nuestra jurisprudencia, hoy probado el delito de hurto simple, la pena es de vergüenza pública y ocho años de galeras, el segundo cien azotes, y diez años de galeras, segun las Leyes 7 y 9 del tít. 11 , lib. 8 de la Recopilacion, y que en los calificados que por la Ley 8 del mismo lib. y tit., se conmutan en galeras la pena capital de los mas de los delitos segun la calidad de ellos, que la pena lo mismo, sin arbitrio en el juez, deberá ser lo menos de diez años de presidio ó galeras, y cien azotes que señalan las Leyes á los hurtos que nunca se castigaron con pena capital, y segun la opinion de V.m. y lo que dice se practica de doscientos azotes, si el sujeto no fuese noble, y que el juez quando mas podrá arbitrar en los cien azotes, imponiendo los doscientos ó los ciento. Ab.: Lo has entendido bien, y añade, que supuesto de que el delito calificado siempre se ha castigado mas que el segundo simple hurto, si sin justa causa el juez por su mero querer no le impusiere los doscientos azotes, y sí solo los ciento que al hurto no calificado, hace mal, porque como digo, las Leyes no le dan tan libre facultad».

79 Sentencias, leg. 28582, s. de vista de 5 de octubre de 1608, el fiscal de S.M. y Juan Antonio, preso, doscientos azotes y diez años de galeras, el pregón: «Esta hes la justicia que manda açer el Rei [a este] honbre por ladron manda le sean dados duçientos açotes y sea llevado a [las galeras] de Su Magestad por diez anos y no los quebrante so pena de muerte y para que a el sea castigo [y a] otros exenplo quien tal açe que tal pague». Sentencias, leg. 28582, s. de vista de 29 de noviembre de 1611 , el fiscal de S.M. contra Juan Geirao y Pierre Broarte, cien azotes y cuatro años de destierro del reino, el pregón: «Esta es la justicia que manda acer el Rei nuestro Señor a estos honbres por ladrones mandales dar a cada uno cien açotes y que sean desterrados del Reino por quatro anos y no lo que- 
Contamos con una sentencia interesante, perteneciente al siglo XVI, dictada en una causa por hurtos cometidos por una mujer, condenada a cien azotes y cuatro años de destierro ${ }^{82}$. Considerando las penas previstas en la Pragmática

branten so pena de servirlos en las galeras de Su Magestad para que a ellos sea castigo y a otros exenplo quien tal açe que tal pague». Sentencias, leg. 28525, s. de revista de 13 de abril de 1612, cien azotes y cuatro años de destierro del reino, el pregón: «Esta hes la justicia que el Rey nuestro Señor manda hazer a este honbre por ladron. Manda le sean dadas cien açotes por las calles acostumbradas y que salga desterrado de todo este Reyno por tiempo de quatro anos y no lo quebrante so pena de servillos en las galeras quien tal haze tal pague». Sentencias, leg. 28483, s. de vista de 13 de diciembre de 1691, el fiscal de S.M. con Antonio de Miranda, Feliciano González y Antonia de Caixide, en rebeldía, el primero condenado en doscientos azotes y ocho años de galeras; y, Fariña, Libro 23, Letra F, f. 160 v., el fiscal de S.M. "con Juan Antonio de Miranda, Feliciano de Cabarcos y otros sobre robos».

80 Sentencias, leg. 28524 , s. 24 de noviembre de 1609, el fiscal de S.M. con Gregorio Ferreiro, cien azotes y ocho años de galeras, el pregón: «Hesta hes la justicia quel Rey nuestro Señor manda azer a este onbre por publico ladron manda le sean dados cien açotes y sea llebado a sus reales galeras por espacio de ocho años y que a el sea castigo y a otros exenplo quien tal ace que tal pague». Sentencias, leg. 28537, s. de vista de 3 de diciembre de 1669, el fiscal de S.M. con Luis Álvarez, Pedro Álvarez, Sebastián Fernández, sargento, Antonio Pérez, Juan González, Dominga Vázquez mujer de Antonio Pérez, Sebastián Fernández de Castro, Bartolomé de Puenteareas, en su rebeldía, contiene pena de diez años de galeras y en doscientos azotes: «En la ciudad de la Coruña a siete dias del mes de diciembre de mil y seiscientos y sesenta y nueve años los señores don Juan Pardo de Monçon, don Juan Santos de San Pedro, don Geronimo Altamirano y don Gregorio Perez Dardon mandaron que en el pregon se diga: esta es la Justiçia que el Rey nuestro señor manda açer en estos hombres por ladrones famosos. Y asi lo dijeron», y se ejecutaron estas penas este mismo día; y, Gómez, Libro 60, Letra Fiscal, f. 297, el fiscal de S.M. "con Antonio Perez Luis Albarez y consortes sobre el robo echo a don Jacinto Gayoso y su muger». Sentencias, leg. 28539, s. de vista de 16 de octubre de 1694, el fiscal de S.M. con Juan Douteiro, doscientos azotes y seis años de galeras, por ladrón famoso; confirmada en Sentencias, leg. 28484, s. de revista de 10 de diciembre de 1694; y Fariña, Libro 23, Letra F, f. 158, el fiscal de S.M. «con Juan de Outeyro sobre robos de bodegas».

81 Sentencias, leg. 28526, s. de vista de 2 de septiembre de 1614, el fiscal de S.M. con Bartolomé Valiente, el pregón: «Esta hes la justicia que el Rey nuestro Señor manda acer a este honbre por publico ladron sacrilego manda se le den duzientas azotes y sea llebado a las galeras de Su Magestad y sirba en ellas por galeote al remo y sin sueldo por tienpo de diez anos para que a el sea castigo y a otros exenplo», y los azotes se ejecutaron el día 13 de septiembre. Sentencias, leg. 28483, s. de vista de 6 de febrero de 1688, el fiscal con $\mathrm{D}^{\mathrm{a}}$. Baltasara Antonia de Sequeiros y su curador ad litem, cien azotes y diez años de destierro, pregonando: «Esta es la justicia que manda el Rey Nuestro Señor haçer a esta muger por aver hurtado las alajas y joyas a Nrâ. Señora del Buen Suceso». Me he ocupado de este y otros casos similares en «Hurtos sacrílegos y práctica judicial gallega. Siglos XVIXVIII», en Estudios penales y criminológicos (Santiago de Compostela) 21 (1998) pp. 239-304.

82 Sentencias, leg. 28580 , s. de vista de 24 de diciembre de 1581, en visita de cárcel, el fiscal de S.M. con María Rodríguez, presa: «condenamos en que de la carcel real donde esta sea sacada a caballo en una bestia de albarda con boz de pregonero que manifieste su delito sea trayda por las calles publicas e acostumbradas desta çiudad por donde mandamos le sean dados cien açotes mas le condenamos en quatro años de destierro desta Real Audiencia y de su casa de morada con çinco legoas»; y, su pregón dice: «Esta es la Justiçia que manda fazer Su Majestad a esta mujer por ladrona manda le den çient açotes y se condena en quatro años de destierro por que a ella sea castigo e a otros exenplo». 
de 25 de noviembre de 1552 y sus modificaciones de 1566, cabe destacar en ella las siguientes notas: a los ladrones mayores de veinte años por la primera vez, se les castigaba con vergüenza y cuatro años de galeras, mientras que por la segunda que cometieran este delito, se les condenaba a cien azotes y galeras perpetuas, con una salvedad: los menores de aquella edad y las mujeres de cualquiera no serían enviados a galeras, sino que serían penados y castigados conforme a las leyes del reino (N.R. 8, 11,7). Con esta prevención, parece que la pena impuesta a la ladrona por los alcaldes mayores del reino de Galicia vino a combinar ambas penas: quizás por la calidad de la víctima o el valor de lo hurtado, quizás por tratarse de una reiteración, se le impusieron los azotes y no la vergüenza pública; mientras que el tiempo de destierro es el mismo que la primera Pragmática preveía para los ladrones por su primera vez, aunque debido a su condición de mujer fue desterrada de la audiencia y de sus casas de morada - ni siquiera del reino-.

Existieron robos de casas especialmente graves, como el ocurrido en 1627 en la fortaleza de Montenegro aprovechando la ausencia del dueño, la nocturnidad, el que sólo hubiera criadas y, sobre todo, la más que posible existencia de un importante caudal ${ }^{83}$. Si a ello agregamos la condición nobiliaria y de alférez real, junto con la titularidad de aquella jurisdicción y el encontrarse huidos algunos de los autores de este hecho delictivo, no puede extrañar que se impusieran graves penas corporales, incluidos los azotes, a parte de los acusados ${ }^{84}$.

A punto de concluir el siglo XVII la Audiencia gallega condenó a tres mujeres como robadoras de casas. Fechorías que debieron ampararse en la ceguera de una de ellas, aunque esta deficiencia no impidió que fuera castigada con

83 Particulares, leg. 29051, 257, D. Juan de Montenegro y Taboada contra Fernando Sanjurjo (a. El Nuevo), Gabriel López y Pedro Balseiro. En la querella, presentada a comienzos de 1627, se daba cuenta que Montenegro tenía en casa más de 400 ducados en dinero y más de 2.000 en bienes al cuidado de doncellas y criadas por hallarse ausente, y «los adversos se fueron una noche siendo muy de noche se fueron a la dicha su casa y rompieron las puertas della, quisieron forzar las dichas donzellas y mozas y lo hicieran sino se recogeran en una torre de la dicha fortaleça en lo qual an cometido grave delito y encorrido en las penas en derecho hestablecidas de las quales y cada una dellas a V. Sa. suplica les condene y mande castigar por todo y rigor y pido justicia y costas y juro en forma. El conozimiento hes de V. Sa por ser delito de preposito y caso pensado y rompimiento de casa y ser mi parte Señor de la dicha jurisdicion y los adversos bibir en diferentes jurisdiciones».

84 Sentencias, leg. 28529, s. de vista de 7 de junio de 1631: «al dicho Antonio Carnero le devemos de condenar y condenamos en ducientos azotes y seis años de galeras al remo y sin sueldo no los quebrante pena de muerte, y a los dichos Antonio Douteiro y [Esteban Teixido] mandamos que en qualquiera parte deste Reino que fueren allados sean traidos a la [cárcel] Real deste Reino y por la culpa que contra ellos resulta les condenamos a los dichos Antonio Douteiro y Estevan Teixo en cada uno ducientos azotes y diez años de galeras al remo y sin sueldo no los quebranten pena de muerte, y a la dicha Antonia de Lastres en cien azotes y ocho años de destierro del Reino». Por s. de revista de 1 de julio de 1631 Antonio Carneiro vió reducida su condena a seis años de destierro en la leva del reino.

Hispania, LXII/3, núm. 212 (2002) 849-906 
doscientos azotes ${ }^{85}$. Un siglo más tarde, el robo nocturno de una casa, acompañado de malos tratamientos a sus habitantes ${ }^{86}$, fue durante castigado por la justicia ordinaria de Ferrol que condenó a los reos fugados y a otro que no lo estaba con doscientos azotes y diez años de presidio en Melilla, además de apercibirlos ${ }^{87}$. Llegó por apelación a la Sala del Crimen que, de acuerdo con la mayor punición impuesta a los reos ausentes, mantuvo a los dos primeros su pena, redujo el tiempo de condena de otro con el mismo destino y agravó las de los restantes ${ }^{88}$.

Por otra parte, la configuración socioeconómica de Galicia dio lugar a la comisión de numerosos hurtos de ganado, cuyos autores en ocasiones tenían la consideración de ladrones famosos o públicos. Así le ocurrió a Alonso da Ucha a quien se atribuyeron diferentes hurtos de reses en Las Achas en 1612. Para completar la fama que tenía quebrantó la cárcel para fugarse ${ }^{89}$. La fuga serviría para confirmar en la sentencia su autoría. El promotor fiscal le atribuyó delitos atroces y hurtos de ganados que "por ser tan comunes y hazerse tan comunmente en toda esta tierra se deven castigar con mayor rigor» ${ }^{90}$. A pesar de los descargos hechos por aquel y otros acusados, el promotor alegaba que «segun la qualidad del delito requiere por ser gravisimo atroz y famoso... pena de muerte». Se acumularon todas las causas contra el reo, que fue condenado en

85 Sentencias, leg. 28485, s. de vista de 4 de septiembre de 1699, el fiscal de S.M. con María de Lago, ciega, María Fernández, viuda Nicaela Fernández, criada de dicha ciega, castigadas a azotes y destierro, su pregón: «Esta hes la justicia que manda el Rey nuestro Señor hacer a estas mugeres por ladronas robadoras de casas condenadas Maria de Lago en ducientos açotes. Maria Fernandez en ciento y Nicaela Fernandez a berguenza publica, quien tal haçe que tal pague».

86 Causas, leg. 29201, 27, el oficio de justicia contra Juan Guardiola, José Torres, Juan de la Fuente, Silvestre do Barro, Isabel Sánchez y Juan Antonio Martínez (a. Pistolas), sobre robo de dinero y malos tratamientos hechos a Diego Cernadas, labrador de la feligresía de Santiago de Franqueira. Se inició la causa por la justicia de Ferrol el 26 de febrero de 1780, por haber sido robado de noche Cernadas, a quien los ladrones le dieron patadas, golpes y dejándole atado, como a su mujer y familia con cuerdas; según la víctima, uno de los ladrones fue Silvestre do Barro.

87 El auto asesorado del juez de Ferrol de 12 de abril de 1780: «Dixo devia de condenar y condena a Joseph Torres, Juan de la Fuente, reos fugitivos, sin perjuicio de oirles pudiendo ser havidos y a Juan Guardiola preso en la carcel publica de esta villa, en doscientos azotes, y diez años de presidio en calidad de gastadores, aplicados a los travajos de las fortificaciones de Melilla». Los restantes recibieron castigos más leves.

${ }^{88}$ La s. de la Sala del Crimen de 7 de diciembre de 1780 , confirma el auto definitivo dado por el alcalde mayor de Ferrol contra José Torres y Juan de la Fuente; mientras Juan Guardiola fue destinado seis años y Juan Martínez cuatro a las reales obras de fortificación de Melilla.

89 Particulares, leg. 4.188/78, fiscal de S.M. y Domingo da Mil contra Alonso da Ucha y Alonso Francisco. Se dictó auto de prisión contra Ucha, fue puesto en la cárcel, pero «el dicho Alonso da Ucha juntamente con otros an quebrantado la carçel y se a echo auto de oficio contra ellos y aberiguacion de la fuga».

90 Esta petición se coadyuvó por Domingo da Mil, como dueño de los bueyes, quien, entre otras cosas, pedía el acusado fuera encarcelado, pues «si huye podra ser se pierda por lo menos un galeote para servir a su Magestad». 
instancia a la restitución del valor de los bueyes hurtados, doscientos azotes, cuatro años de galeras y treinta mil maravedíes para la cámara ${ }^{91}$.

Al llegar la causa a la Audiencia y con el fin de averiguar la verdad le condenaron a tormento ${ }^{92}$. Durante el mismo negó haber cometido los delitos de los que era acusado. Esta negativa junto con las tachas de los testigos y la purga de los indicios que existían contra él, debieron mover a los alcaldes mayores para rebajarle la condena impuesta en la instancia inferior hasta dos años de destierro del reino ${ }^{93}$.

A mediados del siglo XVII también queda constancia de la comisión de otros delitos de abigeato realizados por una pequeña compañía de ladrones, cuyos componentes fueron condenados a diversas penas de galeras y azotes ${ }^{94}$. Hay que pensar que los ladrones cuatreros solían ir en gavilla al objeto de realizar mejor los hurtos y evitar las persecuciones de las justicias inferiores, lo que no impedía que en ocasiones fueran apresados conjuntamente. Algo parecido

91 Por auto del juez de Las Achas de 19 de julio de 1613 y «acomulacion de todos los dichos negoçios y de todo acomulado yço publicaçion de testigos... pasado el termyno conclusa la causa por las partes se dio la sentencia del tenor syguyente... Fallo que segun hestos autos y por la culpa que dellos resulta contra el dicho Alonso da Ucha le debo de condenar y por hesta my sentençia condeno a que dentro de seys dias despues que le fuere notificada hesta my sentencia de y pague al dicho Domingos da Myll beynte y tres ducados que paresçe balyan los boyes de que por su fuga y lo mas que resulta deste pleito hesta conbençido y consta aberse hurtado y a que sea sacado de la carçel donde hesta caballero en una bestia de albarda atadas las manos con una soga desparto y con boz de pregonero que manyfieste su delyto y por las calles acostumbradas le sean dadas doçientos açotes y condeno le mas en quatro años de galeras en que mando syrba a Su Magestad al remo y syn sueldo por tienpo y hespaçio de quatro años dellas no salga en pena de conplirlos doblados y en treynta mill mrs para la camara con costas».

92 S. de tormento de 20 de diciembre de 1613: «condenamos al dicho Alonso da Hucha a question de tormento que mandamos le sea dado en la forma ordinaria quedando en su fuerza y vigor todo lo echo y actuado en este pleito». Original en Sentencias, leg. 28525.

93 Sentencias, leg. 28526, s. de vista de 15 de julio de 1615, en virtud de la cual se dio por nula la sentencia del juez de Las Achas, apelada por Alonso da Ucha, preso, tan sólo condenado en dos años de destierro del reino.

94 Sentencias, leg. 28537, s. de vista de 24 de noviembre de 1664, el fiscal de S.M. contra Domingo de Argozón, Domingo de Vigo, Domingo de Argozón Vispo, Domingo Rodríguez de Suruia, Pedro de Faylde, Juan de Vigo y otros, en su rebeldía, contiene condena de doscientos azotes y seis años de galeras; y Gómez, Libro 60, Letra Fiscal, f. 294 v., el fiscal de S.M. «con Domingo de Argozon Antonio Pita y otros, sobre avigeato y otros delitos»; y, en la s. de revista de 24 de enero de 1665 se aumentó a diez años de galeras y doscientos azotes, el pregón: «Esta es la justicia que el Rey nuestro Señor manda hacer a estos dos onbres por ladrones quatreros ba condenado el uno en ducientas açotes y diez anos de galeras contra el otro en duascientas açotes desterrado por diez años presisos fuera del Reyno quien tal hace que tal pague». Sobre este delito me he ocupado en «Abigeatos y otros hurtos de ganado: una visión jurisprudencial (siglos XVI-XVIII)», en Cuadernos de Historia del Derecho (Madrid) 7 (2000) pp. 161-222. LEVAGGI, Abelardo: «El delito de abigeato en los siglos XVII-XIX» en Revista del Instituto de Historia del Derecho Ricardo Levene (Buenos Aires) 24 (1978) pp. 107-177. MARTINEZ De SÁNCHEZ, Ana M.: «El abigeato en Córdoba en el último tercio del siglo XVIII» en Revista de Historia del Derecho de Argentina (Buenos Aires) 18 (1990) pp. 225-246.

Hispania, LXII/3, núm. 212 (2002) 849-906 
había ocurrido en la ciudad de Santiago unos años antes al ser sorprendidos por un oficial de la Hacienda otro grupo de ladrones ${ }^{95}$. Por la declaración de este oficial se tuvo noticia de la fama que tenían de cuatreros ${ }^{96}$, cuya violencia llegó a padecer un carcelero ${ }^{97}$. Incluso se acumuló otra causa anterior contra uno de tales ladrones ${ }^{98}$.

La extensa querella del promotor fiscal da cuenta pormenorizada de una amplia lista de hurtos y otros delitos cometidos por los reos, acusados repetidamente de ladrones famosos y vagabundos calificados, aportando noticias de no haberse cumplido algunas penas, de quebrantamientos de condenas, de complicidades y encubrimientos cuya enumeración sobrepasa los términos de mis objetivos ${ }^{99}$, aunque cabe resaltar los siguiente pasajes:

95 Particulares, leg. 21.711/34, el oficio de la justicia contra Pedro García Juárez, Pedro Varela, Juan Domínguez, Alberto Muñiz, Dominga de Fachal y otros. Se inició el 27 de julio de 1653 ante el Asistente por comparecencia de Amaro da Brea, vecino de Santiago y guarda de los tributos debidos a S.M., «y le dio quenta como en el barrio de san Pedro hestavan tres o quatro ladrones quatreros que ansido tenderos de çestas y a mucho tiempo que andan hurtando en las ferias y caminos ganado de bueys, bacas y cabalgaduras y otras cosas y al presente tienen en su poder un caballo hurtado y su merced oyda la dicha relaçion mando que dicho Amaro da Brea en compañia de Pedro de Meis y otras personas prendiesen los dichos honbres y mugeres y los pusiesen en la carçel publica deste arçovispado».

96 En su declaración Amaro de Brea dijo conocer a todos, «y sabe que los dichos Dominga Garcia y todos los demas arriva mencionados excepto el dicho Pedro Xuarez y su muger tienen fama y estan en opinion publica de ladrones quatreros que hurtan ganados, volsas de dinero y otras muchas y andan juntos en gavilla de feria en feria con este bicio y hes publico y notorio fueron açotados a mui poco tienpo en la villa de Monforte de Lemos».

97 Se dictó auto de oficio el 30 de julio de 1653 y se abrió información porque al intentar poner el alcaide unos grillos a Pedro Juárez se apagó la vela, y este le dió «tan grande golpe con un jarron lleno de agua que le derrivo tres o quatro dientes e hiço una grande herida». Además, ellos mismos en sus confesiones se acusaron recíprocamente de diferentes hechos delictivos. Pedro Varela, mercero, en la séptima pregunta dijo «que tubo notiçia que el dicho Pedro Xuarez hestubiera preso en la çiudad de Orense por aver muerto un berdugo y en la villa de Pontevedra por unos debantales que avia hurtado». Por su parte Pedro Juárez, también mercero, confesó que Varela «estubiera preso por ladron en la Villa de Monforte de Lemos y que alli le avian açotado abra cosa de un mes».

98 Esta causa anterior databa de 1646, recayendo sentencia de la justicia de Santiago de 15 de noviembre de 1646, el oficio de la justicia y el fiscal de S.M. contra Pedro Varela, Miguel Pérez y Pedro Parga, este en rebeldía: «condeno al [dicho] Pedro Varela y Miguel [Perez] que salgan de la carçel de la [torre] de la Plaça donde estan [presos] cavalleros en cada uno [en bes]tia de albarda desnudos de [medio] cuerpo arriva y con boz de pregonero que pregone su delito sean llebados por las calles publicas de esta ciudad y les den a cada uno cien açotes y que salgan desterrados della y la jurisdicion tenporal deste arçovispado por seys anos precisos los quales guarden y cunplan so la pena de que los serviran en las galeras de Su Magestad al remo sin sueldo alguno y atendiendo a su pobreça solamente les condeno en las costas deste proceso".

99 Admitida el 13 de agosto de 1653 por la justicia de Santiago. Los reos debiendo «tener bivienda fixa no lo acen antes son ladrones famosos que con presupuesto de tenderos no tienen otro trato mas que cometer hurtos de cabalgaduras, dinero, pieças de plata, ropa blanca y otras cosas sin tener bivenda fixa siendo continuos vagumundos y aunque por los dichos delitos an estado presos 
- si bien constaba que uno de ellos había sido condenado por el asistente de Santiago con anterioridad en doscientos azotes, "por aver consentido el suso dicho la dicha sentençia se trató de executar, y por no aver ministro y executor de la justicia se delato la execucion asta que fue suelto en una vesita general con ocho años de destierro y antes de cunplirlos entró en esta ciudad» ${ }^{100}$.

- atento a todos los hechos criminales de los que acusaba pedía que fueran condenados «cada uno dellos en las mayores penas en que an encorrido y en la muerte de horca por ladrones pertinaçes yncorrexibles executandolo en sus personas y bienes para que dellos sea castigo y a otros exenplo». En realidad, el último suplicio era el único castigo que les quedaba por sufrir.

Frente a estas alegaciones, la defensa de los acusados pidió su absolución y, entre otras razones, alegaba que "los hurtos que se les ynputan a dichos mis partes no los an cometido ni estan bastantemente berificados», como que los hechos que habían confesado "no son tales que por ellos yncurran en pena corporal y si alguna mui leve»101.

A fines de agosto de 1653 la justicia de Santiago condenó a estos ladrones de la siguiente manera: al que figuraba como cabeza de ellos en doscientos azotes y cuatro años de galeras, a otro que tenía una causa anterior a doscientos azotes y ocho años de destierro, a otro de los hombres en vergüenza pública y cuatro años de destierro, mientras las mujeres fueron castigadas con vergüenza pública y dos años de destierro ${ }^{102}$. Por su parte, los alcaldes mayores en su sentencia de vista confirmaron el fallo anterior, pero agravando la de quienes debían encontrarse al frente de este grupo, con lo cual a ambos se les impusieron

ansi en esta çiudad y condenados a açotes y destierro no lo an cunplido y ansi mesmo an estado presos por ladrones famosos y bagamundos calificados... quebrantando y ronpiendo las prisiones se an salido sin ser castigados, en particular an cometido cada uno dellos los delitos seguientes...» Con referencia al hecho acaecido con el carcelero santiagués, «hes una resistençia calificada y un delito tan atroz que solo por el deve ser condenado en pena de açotes y galeras al remo y sin sueldo y de otra suerte no queda satisfecha esta çiudad ni la Justiçia».

100 Consta además una orden del mandato del asistente de Santiago de 12 de enero de 1646, disponiendo que se persiguieran a los delincuentes que «andan vendiendo por la tierra y azen muchos hurtos, robos y latrocinios", que concluyó con la sentencia transcrita más arriba. Ya habían escapado de la cárcel en 1645.

101 Petición de 22 de agosto de 1653.

102 Aunque no he encontrado la sentencia de 1653 , los autos de esta causa comienzan con el poder otorgado en la cárcel de la Torre de la Plaza de Santiago, el 30 de agosto de dicho año, por Pedro García Suárez, Perdo Varela, Alberto Muñoz, Magdalena González y Dominga Rodríguez, para apelar la sentencia dada por el Asistente de Santiago "por que les condenó a berguenza publica azotes y galeras y otras cosas que dicha sentencia refiere». La sentencia de vista permite completar esta laguna. 
doscientos azotes y ocho años de galeras, que el fiscal suplicó a mayores ${ }^{103}$. A pesar de que este castigo es una de las penas ordinarias previstas para los ladrones en las Pragmáticas filipinas no coinciden la concurrencia de ambas en una misma condena legal, pues o se dan cien azotes y ocho años de galeras, o doscientos azotes y galeras perpetuas, y aun esto para los robos en la Corte. Pero es que menos aun coinciden con las determinadas en la Pragmática de 1566 que aumentó el número de años al remo. Tampoco parece que se aplicaran las penas dispuestas en Partidas para el abigeato ${ }^{104}$, ni las de ladrones famosos ${ }^{105}$, ni tampoco las que corresponderían a su incorregibilidad, como solicitaba el promotor fiscal. En consecuencia, la única explicación sería la conmutación de la pena de muerte correspondiente a estos ladrones cuatreros por la de doscientos azotes y ocho años de galeras, en cuya punición se incluiría la reincidencia y el incidente de los malos tratamientos hechos al carcelero. En todo caso, las penas impuestas, por graves que fueran, eran menores que las ordinarias.

Otra de las gavillas más importantes del reino de Galicia en los últimos años de la centuria ilustrada fue la capitaneada por Juan Antonio Pérez Abeleira, cuyo ámbito territorial se centraba en la jurisdicción de Puenteareas y Petán, dedicándose fundamentalmente al robo de caballerías para su venta en otros lugares, incluido el reino de Portugal. Fueron apresados en mayo de 1788 mientras algunos de sus componentes trasladaban caballerías robadas ${ }^{106}$. En un

103 Sentencias, leg. 28536, s. de vista de 30 de junio de 1655, el fiscal de S.M. contra Pedro García Suárez, Pedro Varela, Alberto Muñiz, Magdalena González y Dominga Rodríguez: «confirmamos las sentencias enesta causa dadas por el alcalde mayor de la ciudad de Santiago a beinte y nueve de agosto del ano pasado de sesiscintos y cinquenta y tres porque condeno a dicho Pedro Garcia Suarez en ducientos açotes y quatro anos de galeras y al dicho Pedro Barela en ducientos açotes y ocho años de destierro y al dicho Alberte Muniz en berguença publica y quatro anos de destierro y a la dicha Madalena Gonçalez en berguenca publica y dos anos de destierro y a la dicha Dominga Rodriguez en berguença publica y dos anos de destierro y de que por parte de los sobredichos para ante nos fue apelado las quales mandamos se guarden cunplan y executen segun y como en ellas se contiene con que los quatro anos de galeras en que fue condenado el dicho Pedro Garcia Suarez sean ocho y los ocho años de destierro en que fue condenado el dicho Pedro Varela sean ocho años de galeras y mandamos que dicho Alcalde execute las açotes y berguença publica en que estan condenados los sobredichos». El fiscal «en quanto a no ser condenados los reos en mayores y mas graves penas suplica della pide se supla y añada a las condegnas a la culpa que resulta de los autos».

104 Con matizaciones podía admitirse la aplicación de las penas del abigeato recogidas en Partida 7, 14, 19. Salvo que se impusiera por el rompimiento de cárcel.

105 Partida 7, 14, 18, castigado con pena de muerte.

106 Causas, leg. 29203, 35, el oficio de la justicia contra Juan Antonio Pérez Abeleira, Juan Antonio Fernández, Manuel González, Juan Barreiro, Manuel Barreiro, Manuel Barreiro, Francisco Prieto (alias Manote), Gregorio Estévez, Simón Prieto y otros, sobre robo de caballerías. Comenzó por auto de oficio de la justicia de Salvatierra a 13 de mayo de 1788 al comunicarle que por una vereda cercana transitaban tres hombres con unas caballerías robadas, en cuyo seguimiento ya venían varios hombres. Consiguieron asegurarlos, aunque uno de los presos se había fugado. Estos autos han de completarse con Crimen, leg. 3, 17, siendo su última pieza la que contiene el extracto de la causa intitulada «El Real oficio de la justicia de Salbatierra con Juan Antonio Perez Abeleira, Juan 
auto de providencia de la justicia de Salvatierra dictada «por los muchos robos de caballerias y ganados» ${ }^{107}$, les condenaba, entre otras, a las siguientes penas: los reos presos a cuatro y ocho años de presidio en África como gastadores; a todos los ausentes en ocho años de presidio; mientras cuatro mujeres, dos presas y otras dos fugadas, en vergüenza y seis años de destierro. Este auto se confirmó en parte por la Sala del Crimen para algunos reos, moderando a otros su estancia en presidio o los envió al más cercano de Ferrol ${ }^{108}$.

Una vez completas todas las diligencias procesales, la justicia de Salvatierra dictó sentencia en virtud de la cual condenó en diez, ocho y seis años de presidio a los hombres, desterró a las mujeres y apercibió tanto a los condenados como a los absueltos ${ }^{109}$. No obstante, la Sala del Crimen introdujo algunas

Antonio Fernandez y otros sobre robos». PalOP Ramos, «Notas sobre la criminalidad en Galicia a finales del siglo XVIII», pp. 205 y 207, da cuenta -a partir de la información enviada por el tribunal gallego al Consejo de Castilla- de un fallo de la Sala del Crimen de la Audiencia, en el primer semestre de 1788, por el cual fueron condenados cuatro reos en diez años de presidio y doscientos azotes por «robos reiterados de ganado y otros insultos", pero no es el que nos ocupa.

${ }^{107}$ Auto de providencia del juez de Salvatierra de 31 de diciembre de 1788, contra Juan Antonio Pérez Abeleira, Juan Antonio Fernández y Manuel González, «apreendidos con siete caballerias robadas en el dia doce de Mayo pasado deeste año y en que despues han resultado reos porlos muchos robos de caballerias y ganados Juan Barreirro... teniendo presente que algunos de los reos tienen calificada vien su mala conduta y excesos y por lo mismo en seguir contra estos la causa nada más se adelantará que gastos y molestias con dilaciones en las carceles en que están por no haber una capaz con bastante yncommodidad y expuestos a fugarse como se ha verificado admas de que algunos de los mismos reos se hallan separados de defensa por todo ello y con arreglo a lo mandado en los reales autos de sala que encargan la brebedad de el asumpto debe de acriminar y determina baxo su superior aprobacion lo siguiente...» Todos ellos fueron condenados a presidio, entre cuatro y ocho años, además de decretar otras prevenciones.

108 El real auto de Sala de 31 de enero de 1789: "Confirmase el auto de probidencia dado por el juez de Salvatierra quanto a Manuel de Torres, Benito Sousa y el compañero que dijo llamarse Pepe, Francisco Rey alias Danzas, Juliana Puyme, Manuela Franqueira, Manuel Rodriguez alias Camulo, Ysabel y Maria Sanchez muger y cuñada de el mismo y Antonio Martinez con tal que la pena de presidio a dicho Torres se entienda unicamente por espacio de seis años, la de dicho Rey Danza por ocho en Africa, y la de Manuel Rodriguez y Antonio Martinez en el Ferrol y el destierro de Juliana Puyme y Manuela Franqueira sin la pena de verguenza sin perxuicio de que siempre que puedan ser habidos o se presenten a disposicion de el Tribunal dicho Benito Sousa, su compañero Pepe y la citada Manuela se les oira conforme a Derecho». Se remitía a la justicia de Salvatierra para que la cumpliera y remitiera el original, con los incidentes de su fuga y de la que hicieron de Tuy.

109 Crimen, leg. $3,17.1^{\text {a }}$, s. 18 de marzo de 1790 , «sobre robos de cavallerias, y ganados, con lo mas que resulta de los autos»: «Fallo atento a los meritos del proceso a que en caso nezesario me refiero, que por lo que de ellos resulta devo de condenar, y condeno a Juan Antonio Perez Abeleira en diez años de presidio, a Francisco Prieto Manote, Simon Prieto, Gregorio Estevez, Joseph Giraldez, Juan Barreiro, Juan Baptista Davila, en ocho; a Juan Antonio Lopez, Antonio Perez, Ygnacio Domingez y Manuel Leandro en seis; que cumplan todos en calidad de gastadores en uno de los de Africa, y no quebranten pena de doblado... Y por esta mi sentencia difinitivamente juzgando, y vaxo la aprobacion de su Excelencia los Señores de la Real Sala del Crimen con quien se consulte por mano del fiscal de S.M. con los autos orixinales».

Hispania, LXII/3, núm. 212 (2002) 849-906 
modificaciones en dicho fallo, puesto que al capitán de la gavilla, fugado, le condenó «en la pena de doscientos azotes y berguenza publica, y se le destina por diez años a presidio, que cumpla en uno de los de Africa» ${ }^{110}$. En la Corona de Castilla la pena de azotes llevaba implícita la de vergüenza pública ${ }^{111}$, frente a lo que ocurría en otros territorios europeos donde figuraban como penas independientes. Por eso resulta muy extraño tan peculiar y arbitraria pena. En todo caso es más moderada que la de muerte, por lo cual no dejaría de ser más que una aplicación práctica de la conmutación prevista para el último suplicio por galeras y ésta, a su vez, por presidio, de conformidad con ciertas leyes recopiladas. Años después Juan Antonio Pérez Abeleira y Simón Prieto fueron arrestados. El fiscal pidió simplemente que se ejecutara en ellos las penas impuestas: al primero de los citados por estar suficientemente probado por su fuga y ser deducible de su confesión ${ }^{112}$. La Sala del Crimen debió de reconsiderar la peculiar y arbitraria pena impuesta al capitán de la gavilla en su rebeldía por lo que, tras oírle, se ajustó más a las penas habituales al imponerle doscientos azotes y diez años de presidio en África «que cumpla con cadena»113.

${ }^{110}$ Crimen, leg. 3, 17.1 ${ }^{\mathrm{a}}$, real auto de la Sala del Crimen de 27 de marzo de 1792: «A Juan Antonio Perez Aveleira se condena en la pena de doscientos azotes y berguenza publica, y se le destina por diez años a presidio, que cumpla en uno de los de Africa, sin perxuicio de oirle siempre quese presente, o sea havido... Se confirma en todo lo demas y execute sin embargo de suplicacion».

111 No obstante, en un bando del Ayuntamiento de Madrid se dispuso, en nombre del rey, "que al cochero que tuviere el atrevimiento de insultar a la tropa cuando está de facción... como ha sucedido en la Plazuela de los Caños del Peral, al salir de la Opera... en que un cochero insultó a uno de los soldados del Regimiento de Dragones de la Reyna... se le censurará la pena de azotes y vergüenza pública... en Madrid a veinte y nueve dias del mes de mayo de mil setecientos y noventa».

${ }_{112}$ Crimen, leg. 3, $17.1^{\mathrm{a}}$, el fiscal, en 19 de diciembre de 1792, manifestaba que respecto a Pérez Abeleira estaba «plenamente acreditado por los autos haver el sobre dicho echo fuga de la carcel de la ciudad de Tuy, donde se allaba arrestado violentando las prisiones ausiliado de otros que tamvien se hallaban en la misma carcel e ygualmente ser un ladron famoso con especificacion de los robos que havia cometido cuia sentencia no ha tenido execucion por hallarse en reveldia, y fugada hasta que ultimamente la justicia de la jurisdicion de Parada lo arrestó, y remitio a la carcel real con su ynforme, en el que no solo asienta que el Juan Antonio Perez es un fino ladron, sino que añade es un vengatibo, y que tan pronto se bea libre hará desatinos; $Y$ aunque a consequencia de lo prebenido en dicha sentencia se le ha tomado su confesion, lexos de haver satisfecho a los cargos que se le hicieron que antes vien confiesa el echo de la fuga y algunos de los robos porque ha sido procesado siendo fribolas, y despreciables, las causales que propone para moderar ambos delitos... Podra la Sala confirmando dicha sentencia mandar se cumpla y execute en anbos particulares de la condena de azotes y berguenza publica, y destino a los diez años de presidio».

${ }_{113}$ Crimen, leg. 3, 17.1 a, real auto de la Sala del Crimen de 7 de enero de 1793: "Como lo dize el fiscal de S.M. y en su consequencia se de vista de la causa a Simon Prieto, Y se condena a Juan Antonio Perez Abeleira en la pena de doscientos azotes y se le destina a uno de los presidios de Africa por termino de diez años que cumpla con cadena. Se le apercive que de echo se dedique a algun oficio, y se separe enteramente de robar cavallerias, ganados, ni otra cosa. De huirse de la carcel, de sorprender el alcaide carcelero y maltratarle pena de mayor providencia, y se execute sin embargo de suplicacion». El 9 de enero se ejecutó esta pena de azotes. 
Otras gavillas se dedicaron a los robos de casas con la finalidad de obtener dinero y alhajas, algo que reportaba más beneficios que las caballerías. Durante la década de 1790 se cometieron algunos delitos en viviendas de las jurisdicciones de Pruzos y Mellid, incoándose sendas causas sobre sospechas de robos y sobre los robos y fugas cometidos por quienes estaban encausados ${ }^{114}$. En sus respectivas resoluciones, tanto la justicia inferior como la Sala del Crimen, castigaron a los reos varones con ocho años de servicio en el Ejército, aunque de acuerdo con su aptitud física podían ser destinados a la Armada ${ }^{115}$. La acumulación de causas contra los anteriores y los restantes miembros de esta numerosa banda, permitió que la Sala del Crimen condenara a sus integrantes, entre otras penas, a diez años de presidio africano a la mayoría de ellos, además de los correspondientes apercibimientos ${ }^{116}$. El principal reo en estas causas fue castigado, cuatro años después y una vez arrestado, en diez años de presidio en África, con la cláusula de retención, y doscientos azotes — quizás por su fuga-, pena esta última que se ejecutó meses después por haber alegado su hidalguía, que no fue probada ${ }^{117}$.

114 Crimen, leg. 5, 7, el oficio de la justicia contra Manuel Feijoo, José Rey, Antonio de Otero, Vitorio López y otros, sobre robos de dinero, alhajas y otros efectos acaecidos en las jurisdicciones de Pruzos y Mellid. Consta que se incoaron por esta última justicia dos causas contra Manuel Feijoo «de nacion portugues», José Rey y María do Río, «sobre sospechas de ladrones», y otra contra Manuel Feijoo "arrestado por el comisionado Anido, y fugas de la carcel de Santiago», María do Río y José Rey «sobre robos».

115 Auto de la Sala del Crimen de 21 de junio de 1793 «sobre sospechas de robos»: «Que en conformidad de la Real Orden con que se halla devia de destinar y destino a Manuel Feixoo y Josef Rey, a cada uno por ôcho años al servicio de las armas y no siendo aptos para ellas al de los reales bageles de S.M. por igual tiempo para cuio efecto la Justicia de Mellid inmediatamente remita con todo seguro a la carcel real deste reino». Auto de la justicia de Mellid de 5 de julio de 1793: «teniendo presente que Manuel Feyxo y Josef Rey se hallan sentenciados cada uno por ocho años al servicio de las armas por Su Señoria el Sr. Governador de la Real Sala del Crimen, segun testimonio que acompañó a dichos reos a su destino».

116 Auto de la Sala del Crimen de 5 de noviembre de 1793: «Se condena a Antonio Mella, Antonio de Otero, Manuel Feijoo, Victorio Lopez, Benito Socasas, Francisco Rodriguez Moreno, y Dn. Manuel Rodriguez Arias a cada uno en diez años de presidio que cumplan en uno de los de Africa... sin perjuicio de oir a los que estan ausentes y fugitibos siempre que se presenten o puedan ser havidos».

117 S. de vista de 19 de abril de 1797, contra Manuel Feijoo «sobre robos»: «confirmamos el real auto de providencia de cinco de noviembre del año pasado de mil setecientos nobenta y tres entendiendose el presidio ympuesto â Manuel Feixoo, con la clausula de retencion, tamvien le condenamos en la pena de doscientos azotes». Un auto de la Sala del Crimen de 4 de agosto de 1797, declaró no haber probado Manuel Feijoo la excepción de hidalguía que opuso a la anterior sentencia: «Declarase no haber probado Manuel Feixoo la excepción de hidalguia que propuso, y en su consequencia se lleve ynmediatamente a puro y devido efecto en todas sus partes la sentencia pronunciada por la Sala en diez y nueve de abril de este presente año con las nuebas costas. Saquese testimonio de la certificacion dada en diez y ocho de junio ultimo por el cura parrocho de san Esteban de Refojo y San Martin de Arrojo, D. Antonio Ulloa, de las cartas que suenan por el escritas, y de que se hizo uso por el citado Feijoo en este expediente...» Se ejecutaron los azotes al día siguiente: «Dentro del apresentado de la carzel real de la ciudad de la Coruña, a cinco dias del mes de 


\subsubsection{Muertes violentas}

Por último, contamos con diferentes testimonios que permiten comprobar la imposición de la pena de azotes en supuestos de muerte violenta. En algunos casos se impuso este castigo, acompañado de galeras o presidio, a quienes participaron como cómplices o colaboradores en diferentes homicidios ${ }^{118}$. En este sentido es interesante, desde la perspectiva jurídica, una muerte acaecida en 1579 en Villagarcía de Arosa cuando la víctima paseaba descuidado por su plaza, pacífico y sin dar ocasión para sufrir daño. Los reos «todos juntos sobre acuerdo y caso pensado trabaron palabras con él», llegando a amenazarle con la muerte para lo cual, aprovechando que iba descuidado, «salieron [con] la dicha determynacion y animo que trayan de le matar» y "por detras a traiçion le dio una gran herida [en la] cavesa de que le rompio los cascos y salio mucha sangre [hasta] morir naturalmente de la dicha herida» ${ }^{119}$. Los agresores fueron apresados, pero dos de ellos se fugaron de la cárcel.

La información de testigos confirmó el hecho relatado y el promotor fiscal pidió que se procediese contra ellos con todo el rigor del Derecho. El caso concluyó por sentencia pronunciada en noviembre de 1582, en virtud de la cual se condenó a Alonso y Bartolomé de Rubianes a pena de muerte y al segundo

agosto, año de mil setecientos nobenta y siete. Yo scrivano de Camara, en cumplimiento del Real auto de Sala que antezede, he hecho conparecer ante mi al que expuso ser y llamarse Manuel Feixoo, se lo hize saber, lehi y notifique para que lo tenga entendido, en cuia consecuencia y de no haver expuesto cosa alguna, se le vajó por el oficial publico al patio de dicha real carzel, en donde le montó en una bestia menor de albarda que tenia prevenida, y desnudo de medio cuerpo arriva, atado de pies y manos, con pie de amigo al cuello, en esta conformidad fue sacado y conducido por las calles publicas y acostumbradas de esta ciudad a voz de pregonero que publicava sus delitos executandose en la persona del sobredicho Manuel Feixó la pena de azotes que previene la sentencia de sala pronunciada en los diez y nueve de abril de este presente año, y ebacuado se le restituyó en la misma forma a dicha real carzel y en ella hize saber a D. Antonio Varela Alcayde carzelero le mantenga con seguridad hasta que salga a cumplir su destino, todo lo que prexedio despues de las diez de la mañana de oy, con mi asistencia y la de un alguacil ordinario de a caballo y quatro alavarderos de a pie con sus alavardas. Y para que conste lo pongo por escrito de que certifico. Benito Antonio Arran Cernadas".

118 Sentencias, leg. 28483, s. de vista de 12 de octubre de 1691, Juan Ambrosio Boceta de Cea, Andres Boceta de Cea, Andrés Blanco del Pino, María Boceta, su mujer, a que salió el fiscal de S.M., con Domingo de San Martín y Andrés de San Martín, su hijo, Andrés de Barros, cirujano, en que Ana Resua, mujer del primero, fue condenada en doscientos azotes y destierro perpetuo del reino; y Fariña, Libro 23, Letra F, f. 160, el fiscal de S.M. "con Domingo de San Martin y otros sobre la muerte de Gregorio Buzeta en Villa Garcia».

119 Particulares, leg. 25.403/2, el Licenciado Medellín, fiscal de S.M. y Pedro de Caamaño contra Alonso de Rubianes, Bartolomé de Rubianes, Juan Calvo, Gregorio de Rubianes. La querella se admitió el 3 de marzo de 1579, aproximadamente un mes después de acaecidos los hechos. El conocimiento de este grave y atroz delito - en palabras del querellante- correspondía a los alcaldes mayores "por ser delito grave hecho sobre acuerdo y caso pensado con alebe y traicion y porque el dicho juez los solto a los matadores y tiene con ellos gran amistad segun hes notorio».

Hispania, LXII/3, núm. 212 (2002) 849-906 
además a la pérdida de la mitad de sus bienes, y a Juan Calvo a doscientos azotes y doce años de galeras al remo y sin sueldo, junto con ciertas penas pecuniarias ${ }^{120}$. Se condena al ejecutor directo e inmediato del homicidio a la pena capital y a la pérdida de la mitad de sus bienes, pero no parece que los alcaldes la consideraran muerte cometida a traición - que conlleva la pérdida total de bienes para la Cámara - sino que la debieron juzgar alevosa - pérdida de la mitad de los bienes para aquella- ${ }^{121}$. En ambos casos, obviamente, se valora la fuga en perjuicio de ellos. Mientras que a Juan Calvo, que colaboró con los anteriores y no consta que le asestara a Juan Caamaño ninguna cuchillada, ni se hallaba huido ni rebelde, se le condena a una pena inmediatamente inferior a las anteriores, los doscientos azotes, los doce años — que no es número habitual en el destino remero fijado por las justicias gallegas - y a cierta cantidad pecuniaria. En definitiva, tres diferentes grados de participación en la comisión del homicidio, tres penas diferentes.

En parecidos términos encontramos la causa contra un reo que mató a un matrimonio en Osera a comienzos del siglo XVII. Se habían dictado contra él dos penas de muerte por las justicias inferiores: una natural -impuesta en su rebeldía - y otra civil — galeras perpetuas-. Los alcaldes mayores de la Audiencia confirmaron el destino marítimo, pero revocaron la primera sustituyéndola por una pena extraordinaria y no prevista por la normativa regia, trescientos azotes ${ }^{122}$. No se trataba de una pena nueva, al estar prohibido por el ordenamiento jurídico, sino de la agravación de una legal.

$120 \mathrm{~S}$. de vista de 16 de noviembre de 1582: «condenamos al dicho Alonso, y Bartolome de Rubianes a que en qualquiera parte y lugar que fueren allados, sean traidos a la carzel real desta real audiencia, de donde mandamos, sean sacados caballeros en sendas vestias de alvarda, con sogas desparto a la gargante, en la forma acostunbrada, sean sacados por las calles publicas desta ciudad hasta el rollo o picota desta ciudad, donde mandamos sean aorcados hasta que naturalmente mueran y al dicho Juan Calbo, cestero, le condenamos en ducientos açotes, los quales le sean dados por las calles publicas desta ciudad en la forma acostunbrada y ansimesmo le condenamos en doze anos de galeras por galeote al remo sin sueldo, del qual dicho servicio no se ausente so pena de sirvirlo doblado, mas le condenamos al dicho Bertolome de Rubianes en perdimiento de la mitad de sus vienes para la Camara y a los dichos Alonso de Ruvianes y Juan Calbo en cada cien ducados para la Camara e Fisco de Su Magestad y gastos de justicia por mitad».

121 Vid. N.R. 8, 23, 10 y 8, 26, 10.

122 Sentencias, leg. 28582, s. de vista de 2 de diciembre de 1611 , el fiscal de S.M. con Pedro Rodríguez, preso: «confirmamos la sentencia en este pleito y causa dada por Diego Belasquez de Larcon merino del monasterio de Osera en veynte y un dias del mes de febrero deste ano en que por ella fue condenado en serbiçio de galeras perpetuas y por la mas culpa que contra el dicho Pedro Rodriguez resulta del pleito acumulado de la muerte de Ares Mosquera rebocamos la sentencia de muerte contra el dicho Pedro Rodriguez dada en su rebeldía por el Dr. don Juan de Bibe[ro] juez de comision desta Real Audiencia en doze dias del mes de otubre del ano pasado de nobenta y quatro y aziendo justicia mandamos le sean dados al dicho Pedro Rodriguez trescientos açotes por las calles acostumbradas desta ciudad en la forma ordinaria y con esto mandamos sea llevado a las dichas galeras perpetuas, y dellas no se ausente so pena de muerte y se execute sin embargo de apelacion y

Hispania, LXII/3, núm. 212 (2002) 849-906 
La complicidad en una muerte - por aver sido conplise en la muerte de un bonbre - la vemos castigada en 1714 con cien azotes y diez años de galeras, pero en el acusado concurría su condición de menor de veinticinco años y se hallaba preso en la cárcel real ${ }^{123}$.

Uno de los hechos más graves cometidos durante el siglo XVIII fue la muerte violenta de un clérigo un Viernes Santo cerca de una ermita en la montaña ${ }^{124}$. Un homicidio sacrílego, como lo califica la sentencia, en el que concurre una persona, un tiempo y un lugar religioso, lo cual agravaría, si no el hecho en sí mismo, al menos sus penas. Al reo que se encontraba huido le condenaron a pena de muerte y descuartizamiento del cadáver; y, a uno que se hallaba preso en doscientos azotes y diez años de presidio en Africa, con obligación de obtener la licencia para salir. En la fijación de esta última pena se debió considerar el tormento que padeció el reo, no encontrarse huido y quizás no haber sido el autor material a pesar de su activa participación en el hecho, por lo cual se le rebajó el último suplicio a un grado inmediatamente inferior ${ }^{125}$.

suplicacion». Como ha quedado reflejado más arriba, en el pregón antes de trescientos aparece tachado «ducien», prueba que los trescientos no eran habituales.

123 Sentencias, leg. 28544, s. de vista de 24 de enero de 1714, el oficio de justicia y el fiscal de S.M con Lazaro Vázquez y Bernardo Rodríguez: «condenamos a dicho Bernardo Rodriguez contenido en la caveza de esta nuestrâ sentencia en cien azotes y diez años de galeras que sirba en las de S.M. y para la execucion de esta nuestrâ sentencia sea llebado por las calles publicas acostumbradas en cavalleria de albarda y se pregone su delito de aver concurrido a la muerte de Domingo Gonzalez Biscaino; Y a Lazaro Vasquez contenido en la caveza de esta nuestra sentencia le absolbemos de la acusazion puesta en esta ynstancia por lo que mira a la muerte». Se notificó el mismo día a Bernardo en la cárcel real, ejecutándose a continuación la sentencia de azotes: «Con el pregon del ôficial publico diciendo que por âver sido conplise en la muerte de un honbre se le a condegnado en cien âzotes y diez años de galeras quien tal hace que tal pague»; y Gómez, Libro 60, Letra fiscal, f. 309 v., el fiscal de S.M: «con Sevastian Rodriguez Pesqueto, Bernardo Rodriguez y otros sobre la muerte de Domingo Gonzalez en Monforte».

124 Sentencias, leg. 28555, s. tormento de 3 de marzo de 1753, el Real oficio de la justicia y el fiscal de S.M. sobre la muerte de D. Manuel Quindós, presbítero con Pascual López: «En la ciudad de la Coruña, a tres dias del mes de marzo, año de mil setezientos cinquenta y tres y dentro de la carcel real de ella, yo SSno. de asiento a presencia de su Su Sria. el señor Don Bartholome Valledor del Consexo de Su M. su oidor, y alcalde maior en la Real Audiencia deste Reino. Notifique e hice saver la sentencia antecedente a Pasqual Lopez... y señalar las personas que an dado muerte violenta a Don Manuel Quindós presvitero el dia de Viernes Santo de el año pasado de mil sietezientos cinquenta y uno»

125 Sentencias, leg. 28555, s. de vista de 31 de marzo de 1753, el oficio de la justicia y el fiscal de S.M. con Pascual López, Brígida Fernández do Campo, su mujer, José do Campo, D. Narciso de Oural, y Domingo do Campo, este ausente: «condenamos a Domingo do Canpo en pena de muerte... Y asimismo condenamos a Pasqual Lopez preso en la carcel real de esta ciudad en duzientos âzotes y diez años de presidio en uno de los de Africa en el que sirva por dicho tienpo en calidad de gastador, sin faltar a su cumplimiento ni quebrantarle sin espresa lizenzia del Rey... y que se ejecute en la pena por ella ynpuesta a Pasqual Lopez»; y Gómez, Libro 60, Letra Fiscal, f. 322, el fiscal de S.M: «con Don Narciso Doural y otros complices en la muerte de Don Manuel Quindós en Cervantes». 


\section{ApliCACión PUNITIVA.}

Pero, ¿cuál era la realidad en su aplicación? Desde un punto de vista eminentemente práctico, con relación a los reos condenados por la Real Audiencia del reino de Galicia ${ }^{126}$, y desde una perspectiva cuantitativa, cabe reseñar que durante el siglo XVI de 191 sentenciados en vista que he podido hallar, sólo 10 de ellos fueron castigados con azotes, lo que alcanza el porcentaje del 5,2\%. En otros lugares la situación era bien diferente, como en Valencia ${ }^{127}$, Sevilla ${ }^{128}$, las provincias vascongadas ${ }^{129}$ o los territorios de la Meseta Sur donde actuó la Santa Hermandad ${ }^{130}$.

En el siglo XVII he trabajado con un total de 775 sentenciados en vista, de los cuales aparecen condenados a la pena de azotes un total de 38 reos. El resultado porcentual alcanza durante esta centuria el $4,9 \%$. De esta manera los datos obtenidos acerca de su imposición por parte de la Audiencia de Galicia contrastan con la afirmación de Heras Santos de ser «la pena corporal más ordinaria» en la Corona de Castilla ${ }^{131}$, ya que por encima de ella se situarían en aquel reino el destino marino al remo y la vergüenza pública, sin entrar a considerar la naturaleza del destierro. Por el contrario, mis apreciaciones se encuentran más cercanas a lo expuesto por Hespanha respecto a Portugal, cuando afirma que «los azotes y la marca no se aplican con más frecuencia que la pena de muerte» ${ }^{132}$. En otros lugares parece que la fustigación se impuso con

${ }^{126} \mathrm{He}$ utilizado para estos datos los legajos de sentencias originales, puesto que es la serie que, de momento y hasta tanto no se informaticen los autos de la Serie de Particulares - donde se entremezclan todo tipo de causas--, permite unos cálculos más adecuados. No creo, sin embargo, que los resultados sobre la imposición de la pena de azotes que se puedan extraer de dicha serie modifiquen, en lo sustancial, la información obtenida de Archivo del Reino de Galicia, Serie Sentencias de la Real Audiencia. Asimismo, para completar las noticias obtenidas y facilitar una visión más amplia, he acudido también a las Serie de la Sala del Crimen y de Causas, inbibitorias y requerimientos.

127 SAlVAdOR EstebAN, Emilia: «Tortura y penas corporales en la Valencia foral moderna. El reinado de Fernando el Católico», en Estudis. Revista de Historia Moderna (Valencia) 22 (1996) pp. 263-287, señala entre las penas corporales no capitales la que estudiamos, dando cuenta que alcanzaba el $19 \%$ de las impuestas, aunque la mayoría de los azotados se libraron del último suplicio, p. 275.

128 Aunque no menciona ningún porcentaje, ni detalla si se impusieron en sentencias o como castigos por revueltas dentro de la cárcel, HERRERA PUGA, Sociedad y delincuencia, p. 296, afirma que los presos «recibieron azotes por muy diversas causas, casi innumerables».

129 BAZÁn DiAz, Delincuencia y criminalidad, p. 579, afirma que «la pena de azotes contó con un mayor predicamento entre las autoridades judiciales, como se puede deducir por la frecuencia con que se aplicaba; sin embargo, no fue contemplada con igual profusión en la legislación».

130 MENDOZA GARRIDO, Delincuencia y represión, 1999, pp. 473-489, fundamentalmente, donde pone de manifiesto que la pena de azotes se impuso en más del $40 \%$ de las sentencias por la Hermandad.

${ }^{131}$ La justicia penal, p. 298.

132 «Da 'iustitia' à 'disciplina'. Textos, poder e politica penal no Antiguo Regime», en HesPANHA, Antonio M.: La Gracia del Derecho. Economía de la cultura en la Edad Moderna, Madrid, 1993, pp. 212 y 226. Incluso, a pesar de que Partida 7, 8, 12, al determinar la pena de los parricidas dispuso que «qualquier dellos que mate a otro a tuerto con armas, o con yeruas paladinamente, $o$ 
más asiduidad que el último suplicio ${ }^{133}$. Puede existir una razón que justifique este argumento: aquellos reos que pudieran ser condenados a la fustigación serían, por lo general, los considerados más acostumbrados a delinquir o cuyas atrocidades fueran las más graves y, por lo mismo, capaces de huir rápidamente de la justicia. Sólo cuando la justicia los tuviera en su mano, lo que no siempre ocurriría, les impondría esta pena de ejecución pública, con participación de la comunidad y conocimiento general ${ }^{134}$.

Durante todo el siglo XVIII, de la distribución de penas impuestas por los alcaldes mayores y también por los alcaldes del crimen a los 875 sentenciados en el grado de vista cuyas sentencias originales he manejado, tan sólo 38 fueron azotados. El porcentaje de reos castigados con dicha pena rondaría, según mi estudio, el 3,7\%. Este dato contrasta con los resultados que se ha obtenido Palop a partir de la información enviada por la Sala del Crimen gallega al Consejo de Castilla en el primer semestre de 1788 , ya que dicha pena junto con la de vergüenza pública tan sólo alcanza el $1 \%$ del total ${ }^{135}$. Incluso, el porcentaje que he obtenido sobre el contenido de las sentencias se aproxima, sin alcanzarlos, los porcentajes resultantes de la información remitida mensualmente al mencionado sínodo por otros altos tribunales de la Monarquía durante la década de 1780, aunque el mencionado historiador trate conjuntamente azotes, vergüenza y mutilación o marcas a efectos porcentuales de las penas corporales ${ }^{136}$. Las condenas de la Sala de alcaldes de Casa y Corte tampoco parecen variar de la línea mencionada, de tal manera que, como ha escrito Alloza, "de los castigos crueles y espectaculares que la historiografía tradicional recreó con entusiamo y reiteración se puede decir que únicamente el 0,9 por ciento de los reos de Madrid fue azotado» entre 1750 y $1800^{137}$.

El resultado de las penas impuestas en 260 sentencias de revista consultadas, pertenecientes a los siglos XVI, XVII y XVIII estudiadas es el que sigue: 2 de muerte natural, 47 de galeras, 26 de presidio, 3 de minas, 11 destinados

\footnotetext{
encubierto, mandaron los Emperadores, e los sabios antiguos que a tal que fizo esta enemiga que sea açotado publicamente ante todos, e desi que lo metan en vn saco de cuero». No me consta que se les fustigara antes de ejecutarlos, al menos por lo que respecta a Galicia. ORTEGO GIL, Pedro: «El parricidio en la práctica de la Real Audiencia de Galicia», en Dereito. Revista Xurídica da Universidade de Santiago de Compostela, 5-1 (1996) pp. 245-273.

133 Herzog, Tamar: La administración como un fenómeno social: la Justicia penal de la ciudad de Quito (1650-1750), Madrid 1995, pp. 211-213, se trataba de un castigo frecuente, ya que «al parecer, llegaban a constituir un castigo prototípico, al que recurría la mayoría de los jueces quiteños, especialmente durante el siglo XVIII», Aunque también advierte que su empleo «a modo de corrección» se daba en otras relaciones sociales y familiares jerárquicas.

${ }^{134}$ Sobre la publicidad en la actuación de la justicia, HeRzOG, La administración, pp. 208-211.

135 Esta información y otros datos complementarios han sido aportados y estudiados por PalOP RAMOS, «Notas sobre la criminalidad en Galicia», pp. 201-203 y 205.

136 Palop RAMOS, «Delitos y penas», p. 98-101.

137 AlLOZA, Angel: La vara quebrada de la justicia. Un estudio bistórico sobre la delincuencia madrileña entre los siglos XVII y XVIII, Madrid 2000, p. 256
} 
al Ejército, 16 de azotes, 10 de vergüenza pública, 128 de destierro - con independencia de la exclusión territorial-, 75 pecuniarias, 30 apercibimientos y 57 de diferente, mientras que en 42 casos los reos fueron absueltos. En consecuencia, el orden de importancia cuantitativa de la pena de azotes queda en el $3,57 \%$. De los 16 azotados tan sólo hay una mujer. Su destino último no difiere de lo expuesto para los sentenciados en vista: 10 enviados a galeras —uno a diez años y a pasar por debajo de la horca, tres a 8 años y seis a 6 años- y 6 se marcharon al destierro - dos perpetuos, dos por 4 años y dos por 6 -

De los datos obtenidos de las sentencias originales de vista se pueden entresacar algunos datos complementarios más. De los 86 reos condenados a azotes 7 eran mujeres y. 79 hombres. Sus destinos finales fueron diversos: 59 a galeras - 3 a tres años, 4 a cuatro, 12 a seis años, 13 a ocho años y 27 a diez años-, 9 enviados a presidio - todos durante diez años-, 2 a las minas de Almadén - a cuatro y seis años - y 16 al destierro - siete de ellos perpetuo, de los que cuatro eran mujeres-, además ocho de ellos fueron condenados a diferentes penas pecuniarias.

Con cien azotes se castigó a 13 condenados, con doscientos 71 de ellos, mientras que en sendas ocasiones se impusieron trescientos ${ }^{138}$ y cuatrocientos ${ }^{139}$, de modo que estos dos supuestos aparecen como excepcionales. Cuando se establecen cien o doscientos es habitual que vayan unidos a la pena de galeras o de destierro ${ }^{140}$, con las matizaciones que haré a continuación. No hay constancia que su ejecución hubiera provocado la muerte de alguno de los reos azotados ${ }^{141}$.

138 Sentencias, leg. 28582, s. de vista de 2 de diciembre de 1611, el fiscal de S.M. con Pedro Rodríguez, preso. Pregón: «Esta es la Justiçia que manda hacer el Rei nuestro Señor a este onbre por aver muerto a un onbre y a su muger mandale dar tresçientos açotes y que sirba a Su Magestad en sus Reales galeras por [to]dos los dias de su bida y no lo quebrante so pena de muerte para que a el sea castigo y a otros exenplo quien tal açe que tal pague». Antes de trescientos aparece tachado «ducien», prueba que los trescientos no era la pena ordinaria.

139 Sentencias, leg. 28531, s. de vista de 19 de diciembre de 1637, el fiscal de S.M. y Antonio Rodríguez Baiboda contra María Calbina, doscientos se le darían en Coruña y el resto en Verín, por ser este el lugar donde cometió el delito.

${ }_{140}$ Por ejemplo, Sentencias, leg. 28529, s. de revista de 12 de julio de 1633, el fiscal de S.M. con Martín Vermúdez de Galdo, doscientos azotes y cuatro años de destierro. Sentencias, leg. 28479, s. de vista de 11 de marzo de 1644, el fiscal de S.M. con Gregorio Fidalgo, preso en la cárcel real, doscientos azotes y dos años de destierro del reino. Sentencias, leg. 28533, s. de vista de 24 de diciembre de 1644 , en visita general de Pascua de Navidad, el fiscal de S.M. y Alonso de Noraña, promotor nombrado por al alcalde mayor de Monforte de Lemos contra Pedro López, seis años de destierro del reino y doscientos azotes; y Libros de la Escribanía de Figueroa, Libro 50, Letra F, f. 101 v., el fiscal de S.M. "con Pedro Lopez y consortes sobre robo y escalamiento de casa». Sentencias, leg. 28537, s. de vista de 7 de junio de 1669, el fiscal de S.M. con Domingo Rodríguez, doscientos azotes y diez años de destierro del reino, el pregón: «Hesta es la justicia que el Rei nuestro Señor manda acer en este onbre por ladron y encubridor de otros»; se ejecutó el 22 de junio; y Gómez, Libro 60, Letra Fiscal, f. 292 v., «la justicia de la Puente de la Ulla con Domingo Rodriguez sobre acojer ladrones».

$141 \mathrm{Al}$ respecto, Henting, Hans von: La pena. I. Formas primitivas y conexiones bistórico-culturales, Madrid 1967, p. 421.

Hispania, LXII/3, núm. 212 (2002) 849-906 
Los datos acerca de la preponderancia cuantitativa del doble ciento se aprecian con nitidez en el siglo XVIII puesto que, salvo en dos casos concretos castigados con cien ${ }^{142}$, en todos los demás casos conocidos se decretaron doscientos azotes. Además y con independencia de lo expuesto en el informe presentado a las Juntas del Reino acerca de su escaso uso salvo para supuestos muy concretos referidos al rompimiento de cárcel, por las sentencias estudiadas se puede comprobar su imposición en otros hechos criminales especialmente graves durante esta centuria ${ }^{143}$.

Incluso, desde una proyección más doctrinal, a pesar de que a fines del siglo XVIII los autores aluden a que la pena de azotes estaba desterrada por la costumbre ${ }^{144}$, en la práctica judicial de la Sala del Crimen de la Audiencia de Galicia se continuaba imponiendo, sobre todo para los ladrones agavillados. Sin que faltaran juristas que admitieron su empleo con cierta prudencia en unos términos que recuerdan el pasaje transcrito del Informe de la Junta del Reino ${ }^{145}$.

Por otra parte, ha sido común afirmar que la pena de galeras iba acompañada indefectiblemente de los azotes. No obstante, la práctica de los juzgadores gallegos no se ajusta a este parámetro. En las 88 sentencias de vista de la Audiencia de Galicia del siglo XVI sobre las que he trabajado, de 28 en las que se impuso la pena de galeras ${ }^{146}$, sólo consta expresamente en 7 de ellas que además se sumara el castigo de azotes, mientras que la de vergüenza se añadió en $8 \mathrm{y}$ en las restantes 13 no consta que fuera unida a las citadas, antes al con-

142 Por ejemplo, Sentencias, leg. 28544, s. de vista de 24 de enero de 1714 , el oficio de justicia y el fiscal de S.M. con Lazaro Vázquez y Bernardo Rodríguez, asistido de curador: «condenamos a dicho Bernardo Rodriguez contenido en la caveza de esta nuestrâ sentencia en cien azotes y diez años de galeras que sirba en las de S.M. y para la execucion de esta nuestrâ sentencia sea llebado por las calles publicas acostumbradas en cavalleria de albarda y se pregone su delito de aver concurrido a la muerte de Domingo Gonçalez Biscaino». El condenado era menor de edad, de este modo los alcaldes mayores optaron por la conmutación de la pena de muerte natural.

${ }_{143}$ Véase LARDIZÁBAL Y URIBE, Manuel de: Discurso sobre las penas contrabido a las Leyes criminales de España para facilitar su reforma, Madrid 1782, pp. 192-196. En este sentido y con respecto a su imposición en casos graves, HENTING, La pena. I, p. 422, afirma que «cuando la pena de azotes se aseguró una posición independiente en el sitema penal, sustrajo a la pena de muerte, en un constante avance, todos aquellos casos que parecían más benignos», entre los que enumera la tentativa o la recuperación del botín, entre otros. TOMÁs Y VALIENTE, El Derecho penal, p. 387, sobre la disminución de su aplicación en la Corte durante el siglo XVIII.

${ }_{144}$ Marcos Gutiérrez, José: Compendio de las Varias Resoluciones de Antonio Gómez, Madrid 1789 , p. 30 , donde sostiene que «la pena de azotes no está en uso».

145 LARDIZÁBAL, Discurso, Azotes, pp. 192-196, a la que califica de pena corporal aflictiva, «muy usada entre nosotros para castigar ciertos delitos en la gente del pueblo inferior».

$146 \mathrm{El}$ año de 1597, quizás por la amenaza de la armada inglesa al mando del Conde de Esex o la última tentativa de Felipe II contra Inglaterra, fue especialmente intenso en la imposición de condenas a galeras, tanto por lo que se refiere a su imposición directa como por la vía de amenaza para los supuestos de quebrantamiento o incumplimiento de otros castigos, en concreto de destierro. 
trario aparece como único castigo ${ }^{147}$. Por tanto, durante el siglo XVI de ordinario la pena de galeras no es habitual que en tierras gallegas vaya acompañada de las penas de azotes o de vergüenza, tal y como se recoge en las leyes recopiladas castellanas, en las que aquel castigo indefectiblemente va acompañada de estas últimas. Bastaría para ello repasar la Pragmática de 3 de mayo de 1566. A lo largo del siglo XVII en buena parte de las 360 sentencias originales estudiadas y que contienen la pena de galeras, ésta se impone como pena única -a pesar de que en la práctica totalidad de las disposiciones reales se aplica con azotes o con vergüenza-. De esta manera se aprecia que, de todas las condenas de galeras, sólo en un reducido número se impusieron además los azotes. De este dato se desprende que no siempre los alcaldes mayores de la Audiencia de Galicia impusieron en sus fallos las penas ordinarias o legales, al introducir matizaciones por las cuales se modera el rigor del Derecho. La conclusión parece ser la contraria a la mantenida por otros historiadores: la pena de azotes va acompañada, por lo general o en la mayor parte de los casos, con la de galeras; mientras que este castigo, a pesar de las declaraciones legales, no siempre se impuso junto con la flagelación. Cabe destacar, sin embargo, que en otras jurisdicciones los azotes fueron acompañados de otras penas corporales graves, como la amputación de mano o el desorejamiento ${ }^{148}$.

En la mayoría de las decisiones judiciales que incluyen junto a los azotes la condena al remo el número de años esta es importante, siendo lo ordinario seis, ocho o diez años ${ }^{149}$, con alguna excepción en que se dispuso un tiempo inferior $^{150}$. Hay que resaltar que mientras el destino de galeras es una condena cu-

147 Heras Santos, José Luis: La justicia penal de los Austrias en la Corona de Castilla, Salamanca 1991 , p. 265, afirma rotundamente que «la condena a galeras, por citar unas de las más frecuentes, iban indefectiblemente unidas a cierta cantidad de azotes y vergüenza pública». Cierto que así consta en la legislación recopilada, pero en la práctica judicial de la Real Audiencia de Galicia no aparecían necesariamente unidas ambas penas.

148 MENDOZA GARRIDO, Delincuencia y represión, p. 474, donde afirma que «aunque no de un modo muy frecuente, la Hermandad Vieja aplicaba estas mutilaciones como complemento a los azotes».

149 Entre otras muchas, Sentencias, leg. 28478, s. de vista de 4 de septiembre de 1635, el fiscal de S.M. con Pedro González de Gondaren, doscientos azotes y diez años de galeras. Sentencias, leg. 28536 , s. de vista de 30 de junio de 1655, el fiscal de S.M. contra Pedro García Suárez, Pedro Varela, Alberto Muñiz, Magdalena González y Dominga Rodríguez, contiene condenas de ocho años de galeras y doscientos azotes; y, la causa de la justicia de Santiago contra Pedro García Suarez, por delitos, de 1655, en Particulares, leg. 21.711/34. Sentencias, leg. 28539, s. de vista de 26 de noviembre de 1698, el fiscal de S.M. contra Juan y Amaro González de Bruces, doscientos azotes y seis años de galeras, se ejecutaron los azotes el 29 de noviembre a Amaro, pero a Juan por estar enfermo no se le dieron hasta el 15 de febrero de 1699.

150 Sentencias, leg. 28482, s. 5 de marzo de 1686, el fiscal de S.M. contra Juan López y Antonio Núñez, cien azotes y tres años de galeras, pero la sentencia en grado de revista de 10 de mayo de 1686, la revocó; y Gómez, Libro 60, Letra Fiscal, f. 298, el fiscal de S.M., «con Juan Lopez y Antonio Nuñez sobre robos». Sentencias, leg. 28542, s. de vista de diez de diciembre de 1709, el fiscal de S.M. con Francisco Rodríguez, quien había sido condenado por el corregidor de Orense a vergüenza pública y ocho años de galeras, convertidos en doscientos azotes y tres años de remo por los alcaldes 
ya finalidad última es el servicio a la Corona, al Estado, la imposición de la pena de azotes permite satisfacer al pueblo y facilitar su participación en la represión de la delincuencia. Además, mediante la representación pública de la pena de azotes a la comunidad le consta fehacientemente el triunfo de la justicia y el castigo del reo, porque una vez trasladado a la galera su cumplimiento deja de ser manifiesto para los habitantes más cercanos al lugar de comisión del hecho delictivo. El rey, y en su nombre, los jueces lo entregan al pueblo una vez sentenciado y, ejecutada la pena de azotes, vuelve a poder del rey.

En la misma línea de lo que acabo de exponer, un número considerable de destierros decretados por los jueces gallegos y por su Audiencia llevan aparejada alguna pena pecuniaria de cuantía variable y, en menor medida, azotes ${ }^{151}$.

Llegados a este punto es preciso hacer una somera referencia a las penas que se establecían en las sentencias para el caso de quebrantamiento de las condenas fijadas en ellas o previstas para el supuesto de una posible reiteración en la comisión delictiva. Conviene resaltar que, en algunos casos, esta so pena era, precisamente, la pena ordinaria determinada por la legislación regia; mientras que la impuesta al reo, en realidad, era arbitraria y establecida por los propios alcaldes mayores valoradas diferentes circunstancias ${ }^{152}$. La cláusula de quebrantamiento es interesante puesto que si el reo era condenado a galeras y azotes, la sanción por su quebrantamiento era la muerte; mientras que si los azotes iban acompañados de destierro la cláusula era bajo la amenaza de galeras, con una excepción: si el destierro era perpetuo - muerte civil- la so pena era la muerte — natural ${ }^{153}$ -

mayores del reino. El mismo día le fue notificada por el escribano la sentencia y el oficial público verdugo- "sacó de dentro de la carzel real deste Reino a Francisco Rodriguez, contenido en la sentenzia antezedente, cavallero em una bestia de albarda y con su pie de amigo al pesquezo desnudo de medio cuerpo arriva y por las calles publicas desta ciudad y con voz de pregonero en las partes acostumbradas dellas se executo en el la dicha sentencia quanto a los azotes, y de echo le bolvio a entrar dentro de dicha carzel y le entrego a Andres de Lodeiro, alcaide della».

151 TOMÁs Y VALIENTE, El Derecho penal, p. 392, afirma que la pena de destierro «casi nunca se imponía sola, sino acompañando a la de azotes y vergüenza». Para nuestro caso, son proporcionalmente escasas las sentencias de la Real Audiencia de Galicia en las cuales se impuso conjuntamente destierro y alguna de las citadas, ya que lo más habitual fue la condena pecuniaria.

152 Consta, incluidas sentencias de vista y revista, la so pena de muerte en 38 sentencias; en 61 la pena de galeras; en 12 el presidio; en 3 doscientos azotes; la vergüenza pública en 4; el destierro, por lo general del reino, 73; y diferentes penas pecuniarias en 10 de ellas.

153 Sentencias, leg. 28479 , s. de revista de 24 de mayo de 1644, el fiscal de S.M. con Gregorio Fidalgo, preso en la cárcel real, condenado a doscientos azotes y destierro perpetuo del reino, se le notificó en el patio de la cárcel real el 28 de mayo, se le desnudó de cintura para arriba, se le puso en una bestia de albarda «y el dicho ofiçial publico le ato con una soga los pies y manos y en la manera referida", fue sacado de la cárcel y se ejecutó la pena de azotes por las calles acostumbradas, con el pregón: «Esta es la justicia que el Rey nuestro Señor manda acer a este ombre por ladron condenado en duzientas açotes y desterrado del Reino perpetuamente y no lo quebrante pena de diez anos de galeras al remo y sin sueldo"; y, fuera de la Puerta de la Torre y trincheras se le hizo saber de nuevo la pena de destierro. 
Del estudio comparado entre diferentes territorios hispanos y europeos parece desprenderse que los azotes se impusieron en casos en los cuales se intentaba moderar la pena de muerte natural y singularmente, como se puede apreciar por los datos obtenidos de la información conservada de la Real Audiencia de Galicia y otros ámbitos judiciales, para los hurtos de diferente gravedad. A la misma conclusión llega Mendoza Garrido al estudiar la actuación de la Santa Hermandad a comienzos del siglo XVI, para quien «llama la atención que cuando disponemos del texto de las sentencias los alcaldes hacen gala de su magnanimidad, mencionando que condenan al acusado a pena de azotes actuando con benevolencia, pero que podrían haberle condenado a penas mayores, pudiéndose pensar que se refieren a la pena de muerte» ${ }^{154}$. Algo similar sucedió en Borgoña, como expone Ulrich, para quien «le justice bourguignone usa avec modération de la peine de fouet. Jusqu'en 1740 moins de 1/10 des condamnés sont fustigés, cette proportion va légèrement augmenter ensuite pour rester stable jusqu'en 1785 . Aprés cete date, la progression est trés nette puisque prés de $1 / 5$ des condamnés reçoit le fouet. La répression faiblissant, le fouet remplace des peines plus rigoureuses pour certains délinquants, essentiellment les voleurs. Le fouet était, en effet, le plus souvent réservé aux auteurs de vols simples, mais dans les dernières annés de l'Ancien Régime la Cour en fera "bénéficier» les auteurs de vols qualifiés. Pendant longtemps la Cour précisera que le condamné devra être fouetté jusqu'au sang; cette formule disparaîtra progressivement dans les arrêts à partir de 1760 » $^{155}$.

La regla para la poner imponer a un reo el castigo que nos ocupa era la siguiente: «en los pleytos criminales, se han de ver por tres Iuezes, assi en vista, como en revista, y para hazer sentencia conteniendo pena corporal, han de concurrir tres votos conformes de toda conformidad, y lo mesmo se entienda en caso que se mande executar la sentencia de vista, sin embargo de apelacion, o suplicacion» ${ }^{156}$.

De otro lado y con relación a la forma de su cumplimiento pueden distinguirse las siguientes variantes:

- la llamada forma acostumbrada, es decir la habitual u ordinaria ${ }^{157}$, suponía que, tras sacarlos de la cárcel, se les daba un par de azotes en cada una

${ }_{154}$ Delincuencia y represión, p. 477.

15s UlRICH, D.: «La répression en Bourgogne au XVIIIe siècle», Revue bistorique de Droit français et étranger (París) 3 (julio-septiembre, 1972) p. 423.

156 Ordenanzas de la Real Audiencia del Reino de Galicia, Santiago de Compostela 1679, Lib. I, I, 47; la que se vuelve a reproducir, en términos casi iguales en Ordenanzas, Lib. II, VII, 2.

157 Sentencias, leg. 28476, s. de vista de 17 de noviembre de 1604, el fiscal de S.M. con Diego López Reymondez: «le condenamos en ducientos açotes que le sean dados en la forma acostumbrada por las calles publicas desta ciudad». Sentencias, leg. 28582, s. de vista de 5 de octubre de 1608 , el fiscal de S.M. con Juan Antonio, preso: «le condemnamos en duzientos açotes que les sean dados por las calles publicas desta çiudad en la forma hordinaria». Sentencias, leg. 28537, s. de vista de 7 de

Hispania, LXII/3, núm. 212 (2002) 849-906 
de las esquinas — cuando estaban condenados en doscientos, o uno si sólo lo estaban en cien- de las calles de la ciudad y la Pescadería de Coruña como sede de la Real Audiencia, en bestias de albardas, con pie de amigo para evitar que los reos escondieran la cabeza ${ }^{158}$, desnudos de cintura hacia arriba ${ }^{159}$, atados de pies y $\operatorname{manos}^{160}$ o con grillos, y siempre con voz de pregonero que anunciaba su delito ${ }^{161}$.

junio de 1669, el fiscal de S.M. con Domingo Rodríguez: «duçientas açotes para lo qual sea sacado de la carçel real en la forma ordinaria». Sentencias, leg. 28483, s. de vista de 6 de febrero de 1688 , el fiscal de S.M. con Da . Baltasara Antonia de Sequeiros a la que dieron un azote en cada esquina hasta el ciento, como se acostumbraba.

158 Sentencias, leg. 28539, s. de vista de 16 de octubre de 1694, el fiscal de S.M. con Juan Douteiro: «Duzientos açotes que les sean dadas por las calles publicas desta ciudad a boz de pregonero que publique su delito de ladron famoso", se le notificó el mismo día en la cárcel real e inmediatamente se ejecutó la pena de azotes «por Gregorio Louro oficial publico desta ciudad caballero en una bestia de albarda desnudo del medio cuerpo arriva con un pie de amigo al pescuezo por las calles publicas desta ciudad». Sentencias, leg. 28485, s. de vista de 10 de abril de 1699, el fiscal de S.M. contra Antonio Pestañas, Sebastián de Salazar, Bernardo Melchor de Araujo, Pedro Martínez, Isabel Salgado, Angela Magro y Bernarda de Baños: «en ducientos açotes cada uno y en quanto â esto se execute sin enbargo a caballo en bestias de albarda por las partes âçostumbradas por el executor de la Justiçia». Se notificó a Sebastián de Salazar y Bernardo Melchor de Araujo, presos en la cárcel real de Coruña, ejecutándose en ellos la pena de azotes, cada uno en su bestia de albarda y desnudos de medio cuerpo arriba, con su pie de amigo al pescuezo por las calles acostumbradas y voz de pregonero; fue confirmada por s. de revista de 16 de mayo de 1699 , con rebaja en los años de remo.

159 Son conocidas las palabras de LARDIZÁBAL, Discurso, p. 196, en contra de esta práctica: «Creo también muy digna de reforma la práctica que actualmente hay, cuando se sacan las mujeres a la vergüenza de llevarlas desnudas de medio cuerpo arriba con los pechos descubiertos, lo que ciertamente ofende la modestia, y he visto causar este efecto aun en las gentes del bajo pueblo. En algunas partes van cubiertas por delante, dejándoles solamente descubiertas las espaldas, lo que es más conforme a la decencia, y por otra parte no se disminuye nada la pena de la vergüenza».

160 Sentencias, leg. 28479, s. de revista de 24 de mayo de 1644, el fiscal de S.M. con Gregorio Fidalgo, se le notificó en el patio de la cárcel real el 28 de mayo, se le desnudó de cintura para arriba, se le puso en una bestia de albarda "y el dicho ofiçial publico le ato con una soga los pies y manos y en la manera referida», fue sacado de la cárcel y se ejecutó la pena de doscientos azotes por las calles acostumbradas, con el pregón correspondiente.

${ }^{161}$ En Valencia se distinguía entre azotar en las barras, por infligirse al reo atado en las barras existentes en la calle de la prisión, del simple azotar, que se ejecutaba haciendo el paseo o cerca por los lugares acostumbrados de la ciudad, SALVADOR ESTEBAN, «Tortura y penas», p. 274. En otros lugares se azotaba al reo sujeto al rollo o picota, sin perjuicio de darle el llamado paseo en la lengua germanesca. BAZÁN DIAZ, Delincuencia y criminalidad, p. 580. La Hermandad en Ciudad Real podía optar por el paseo o fustigarle en el palo, MENDOZA GARRDDO, Represión y delincuencia, pp. 483 y 489. Los jueces de la Audiencia de Buenos Aires los aplicaron de diversas maneras, LEvaGgi, Manual de Historia del Derecho Argentino, II, p. 298. También el clásico BERNALDO DE Quirós, Constancio: La picota: crímenes y castigos en el país castellano en los tiempos medios, Madrid 1907. La Recopilación de Indias, $7,5,21$, dispuso que «al negro, o negra ausente de el servicio de su amo quatro dias, le sean dados en el rollo cincuenta azotes, y que esté allí atado desde la execucion, hasta que se ponga el sol; y si estuviere mas de ocho dias fuera de la ciudad una legua, le sean dados cien azotes, puesta una calza de hierro al pie, con un ramal y descubiertamente la trayga por tiempo de dos meses». 
- las formas especiales implicaban un plus de ignominia. La más suave podía ser su ejecución sobre un reo/a tocado con coroza - hay variantes sobre los signos colocados en la cabeza, incluido el rapado de pelo ${ }^{162}$ y un rótulo que delatara su delito ${ }^{163}$, que es la más cercana a la de los lenones, en los cuales la fusta era, como ya vimos, una ristra de ajos. No obstante, dentro de estas cabe resaltar la ejecución material agravada al ordenarse que se le dieran los azotes alrededor de la horca ${ }^{164}$,

162 Por ejemplo, «si la sentencia es de azotes estando confirmada por la Real Sala del Crimen, se notifica al reo en la carcel y luego hara que los ministros de justicia lo desnuden de la cintura para arriba, le quiten el pelo de la caveza y amarradas las manos con una argoya al cuerpo y un grillete lo executen, y la execusion es de esta manera...", según un Formulario de causas criminales redactado alrededor de 1751, publicado por GARCIA LEÓN, Susana: «Un Formulario de causas criminales de la Nueva España» en Anuario Méxicano de Historia del Derecho (México) 9 (1997) pp. 83-148/142-143. En Madrid mediado el siglo XVII fueron quemados tres monederos falsos, mientras que recibieron azotes el que hizo las planchas y sus amigas, además de ir a sus respectivas galeras, y según refiere BARRIONUEVO, Jerónimo de: «una de las azotadas fue la que en las tramoyas del Retiro echó pregón, cantando con mucha gracia, lo cual todo se redujo a que, rapada toda la cabeza, despreciada y desvalida, la pasearon azotando por las calles de Madrid», Avisos (ed. de A. Paz y Melia), Madrid 1969, Tomo II, pp. 225-226.

163 Muestra de conjunto es Sentencias, leg. 28531, s. de vista de 19 de diciembre de 1637, el fiscal de S.M. y Antonio Rodríguez Baiboda contra María Calbina: «duçientos açotes que le sean dados en la forma hordinaria por las calles acostumbradas de esta ciudad con çoroça, mas le condenamos en otros duçientos açotes que le sean dados en la villa de Berin en la misma forma donde cometio el delito»; y, Sentencias, leg. 28531: «En la ciudad de la Coruña a diez y nuebe dias del mes de diziembre de mill y seisçientos y treinta y siete años para efeto de que se execute la sentençia de bista dada contra Maria Calbina en quanto a las ducientas azotes que por dicha sentenzia se le mandar dar por las calles acostunvradas desta çiudad. Y otros duzientos en la Villa de Berin y en diez años de destierro preçisos deste Reyno. Y que no los quebrante pena de muerte, estando puesta dicha Maria Calbina enzima de una bestia de albarda desnuda dende la çintura arriba junto de la carzel real que se abia bajado della para dicho efeto presente Domingo do Feal oficial publico para cumplir la sentenzia a la sobredicha y al dicho dicho ofiçial publico para que executase dicha sentencia en quanto a las duçientas açotes, el qual lo hizo trayendole por las calles desta ciudad en la forma acostunbrada de que doy fee siendo testigos...» Su pregón: «Esta es la justicia que el Rey nuestro Señor manda azer a esta muger por testigo falso y por aver sido en el pleito de Antonio Rodriguez Bayboda, su muger y yerno porque se le mandan dar duzientos azotes en esta ciudad y otros duzientos en la billa de Verin y diez años de distierro pena de muerte, quien tal ace que tal pague».

164 Sentencias, leg. 28482, s. de vista de 3 de agosto de 1686, el fiscal con Andrés dos Casas, condenado a doscientos azotes "que le diesen alderredor de la horça de dicha jurisdicion» y en seis años de galeras; pero de acuerdo con la s. de revista de 31 de agosto de 1686, se ejecutó el 19 de octubre de 1686 la pena de azotes por las calles acostumbradas; y Gómez, Libro 60, Letra Fiscal, f. 297 v., el fiscal de S.M. «con Andres das Casas y qonsortes sobre robos en la jurisdicion de Moeche». Sentencias, leg. 28538 , s. de revista de 21 de febrero de 1689, el fiscal de S.M. con Pedro Rodríguez de Araujo, condenado en vista en ducientas azotes que le fuesen dadas por las calles publicas y acostunbradas desta ciudad y que se executase sin envargo de suplicaçion y le sacasen con otro ajusticiado y pasasen por devaxo de la orca» y diez años de galeras, ya estaba condenado en otra causa -s. 14 de marzo de 1693-; y Fariña, Libro 23, Letra F, p. 147, el fiscal de S.M. «y el oficio de la justicia con Pedro Rodriguez de Araujo sobre robos». Otra noticia similar en TOMÁS Y VALIENTE, El Derecho penal, p. 397.

Hispania, LXII/3, núm. 212 (2002) 849-906 
sin duda para advertirle que por encima de los azotes — pena ignominiosa en extremo- ya sólo quedaba el último suplicio.

Los testimonios del siglo XVIII son más expresivos, aunque el ceremonial de darlos siguió el estilo acostumbrado ${ }^{165}$, con alguna peculiaridad concreta ${ }^{166}$, aunque hay descripciones muy pormenorizadas. Se notificaba el mismo día al reo en la cárcel real, ejecutándose inmediatamente la sentencia de azotes:

«y por el ôficial publico executor de la justicia se le puso cavallero en una bestia de albarda se llevo por las calles âcostumbradas con mi asistencia y de quatro alguaciles hordinarios desta Real Audiencia y en cada una de dichas partes âcostumbradas se le dava un âzote con el pregon del ôficial publico diciendo que por

165 Sentencias, leg. 28486, s. de vista de 22 de abril de 1701, el fiscal de S.M. con Juan do Pico, con su pregón: «Esta es la justicia que manda el Rey nuestro Señor a este honbre por ladron condenado a cien açotes y seis años de galeras quien tal hace que tal pague»; se le notificó el 22 de abril en la cárcel real de Coruña y este día se ejecutó la pena de azotes, para lo cual, "fue sacado desta carcel real donde estaba, caballero en una bestia de albarda por las calles acostunbradas con voz de pregonero y se executo la sentencia en el sobredicho de cien açotes dando en cada esquina, parte acostumbrada una, y se bolvio a dicha carcel real donde estaba». Sentencias, leg. 28540, s. de vista de 17 de diciembre de 1701, el fiscal de S.M. y Andrés Lorenzo de Caamaño con Domingo Díaz (a. Lobo) y Juan Baluga, la pena de azotes se ejecutó el mismo día, por las calles acostumbradas y manifestando en voz alta sus delitos: "esta es a justicia que el Rei nuestro Señor manda açer a este onbre por ladron quatrero condenado en duçientos azotes y diez anos de galeras, quien tal açe que tal pague $\mathrm{Y}$ le fueron dadas en las esquinas y plaças asta la puerta de la Torre y buelta asta la carcel en cada una dos conforme se estila». Sentencias, leg. 28541, s. de vista de 20 de octubre de 1706, el Oficio de justicia con Roque Galiano, Eufrasio de Rivera, Alonso Merino, Juan Medelo, Antonio Fernández, Jacinto Carvallo y Andrés de Amil, curador de este, y todos presos en la cárcel real: «Cada uno en duçientos açotes para lo qual sean sacados de la carçel real donde se allan en bestias de albarda por las calles publicas con boz de pregonero que publique su delito». Sentencias, leg. 28545 , s. de vista de 21 de febrero de 1716, el fiscal de S.M. con Francisco Cosme García, condenado en doscientos azotes y cuatro años de galeras «para lo qual sea sacado de la carzel donde se alla y por las calles acostunbradas publicando su delito de ladron y usar de polbos benenosos y por esta nuestrâ sentencia asi lo pronunciamos y mandamos y que se ejecute sin enbargo de suplicazion»; le fue notificado en la cárcel real al día siguiente y a continuación se ejecutó la fustigación, caballero en bestia de albarda, con pie de amigo al pescuezo, por las calles de la ciudad y Pescadería "y a las esquinas publicó su delito diciendo: esta es la justicia que el Rey nuestro Señor manda hacer en este hombre por ladron y usar de polbos benenosos».

166 Sentencias, leg. 28546, s. de vista de 21 de febrero de 1721, el fiscal de S.M. con Cosme Blanco: "para ejecutar parte de esta nuestrâ sentencia mandamos que el referido Cosme sea sacado de la carzel y puesto en bestia de albarda por las calles acostunbradas de esta ciudad y sitios señalados se le den los azotes y se publique se ejecuta la sentencia por ladron... y se ejecute sin enbargo de suplicazion», se le notificó en la cárcel real al día siguiente e inmediatamente se ejecutó la de azotes, caballero en bestia de albarda, con pie de amigo al pescuezo, las manos atadas y grillos en los pies, fue llevado por el oficial público de la ciudad de Santiago, mandado llamar para este efecto, el cual fue publicando: "esta es la justicia que el Rey nuestro Señor manda hacer en este onbre por ladron condenado a duzientos azotes y diez años de galeras al remo y sin sueldo, quien tal hace que tal pague», hasta la Puerta de la Torre de Abajo y vuelta a la cárcel real. 
âver sido conplise en la muerte de un honbre se le a condegnado en cien âzotes y diez años de galeras quien tal hace que tal pague y para que dello conste y de que se bolvio el reo â la carcel y entrego al âlcaide della lo firmo dicho dia» ${ }^{167}$.

La literatura también dejó pasajes memorables acerca de su ejecución. Los versos de Quevedo están llenos de sarcasmo. Así, en su conocida Carta de Escarramán a la Méndez se incluyen una magnífica descripción:

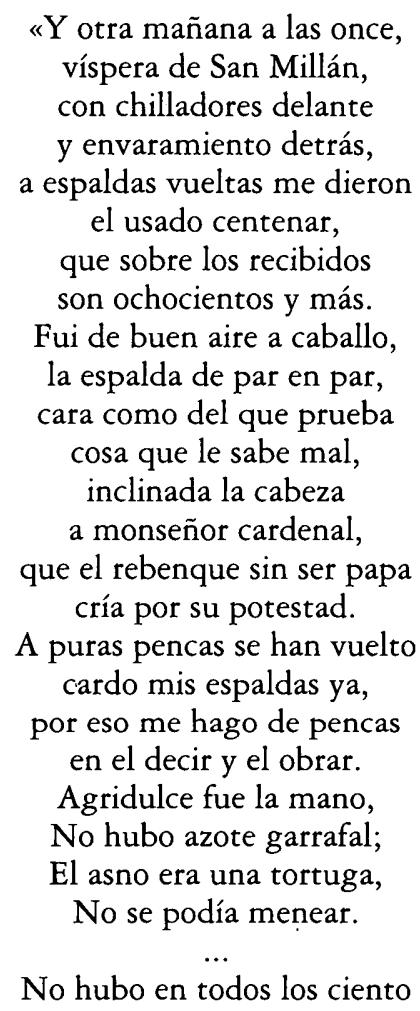

167 Sentencias, leg. 28544 , s. de vista de 24 de enero de 1714 , el oficio de justicia y el fiscal de S.M. con Lazaro Vázquez y Bernardo Rodríguez, con curador. Sentencias, leg. 28560, s. de vista de 19 de noviembre de 1791, el Real oficio de la justicia y el fiscal de S.M. con Melchor Somoza, platero, Pedro de Cuns, Silvestra Silbade, su mujer, Andrés González, fabriquero de Santa María de Ribasar, D. José de Luaces, Domingo Antonio de Souto y otros, «sobre robos y otros excesos», el día 19 de noviembre se notificó la sentencia en el apresentado de la cárcel real a Domingo Pérez y hallándose presente el oficial público, «le bajo al patio de dicha carzel y monto en una cavalleria de albarda que a este fin tenia prevenido, atandole de pies y manos, con pie de amigo al cuello, y en esta conformidad con mi asistencia, la de dos alguaciles ordinarios y quatro alabarderos con sus alabardas, fue llebado por las calles publicas y acostumbradas de esta ciudad y su Pescaderia, pregonando el delito por que se le ha procesado y su destino, ejecutandose en los sitios acostumbrados la pena de azotes que dicha sentencia comprende, y evacuado uno y otro se le bolvio a dicha carcel». 
Azote que echar a mal;

Pero a traición me los dieron,

No me pueden agraviar.

Porque el pregón se entendiera

Con voz de más claridad,

Trujeron por pregonero

Las sirenas de la mar.

Contribúyeme con algo,

Pues es mi necesidad

Tal, que tomo del verdugo

Los jubones que me da...»168

De otra parte, en principio y salvo los supuestos excluidos por Derecho, las sentencias eran recurribles. No obstante, en casi la práctica totalidad de los fallos de la Real Audiencia en los cuales se establecía la ejecución de la pena de azotes, se insertó la cláusula que se procediera a ella sin embargo de suplicación ${ }^{169}$. Esta medida podía implicar que el mismo día después de pronunciarse la sentencia y una vez notificado al reo se ejecutara el castigo ${ }^{170}$.

168 Cito por la Antología ya referida. La Respuesta de la Méndez a Escarramán también deja un pasaje ilustrativo: «Si tantos verdugos catas,/ sin duda que te querrán/ las damas por verdugado/ y las izas por rufián./ Si te han de dar más azotes/ sobre los que están atrás,/ estarán unos sobre otros/o se habrán de hacer allá./ Llevar buenos pies de albarda/ no tienes que exagerar,/ que es más de muy azotado/ que de jinete y galán... Espaldas le hizo el verdugo,/ mas debiose de cansar,/ pues habrá ocho días/ que se las deshizo ya».

169 Por ejemplo, Sentencias, leg. 28543 , s. de vista de 24 de enero de 1711 , el oficio de justicia y el fiscal de S.M. con Juan da Pedra: «Y asi mismo le condegnamos en ducientos açotes y quanto a elllos se execute sin enbargo de suplicacion»; se le notificó el mismo día en la cárcel real e inmediatamente se ejecutó la pena de azotes, "cavallero en una bestia de albarda y con su pie de amigo al pescuezo desnudo del medio cuerpo arriva y por las calles publicas desta ciudad y con voz de pregonero en las partes acostumbradas della se executo en el dicha sentencia quanto a los azotes y de echo le bolvio a entrar dentro de dicha carcel».

170 Sentencias, leg. 28549, el fiscal de S.M. y Francisco Alcalde Cobas Rubias y otros contra José de Villanueva, Domingo Costoya, Antonio María, Lucas Cuadrado, Agustín Antonio Pérez, Antonio Rodríguez y otros. Se les notificó la s. de vista de 25 de septiembre de 1732, a Antonio Pérez y Antonio Rodríguez (Barrabás) y el mismo día se ejecutó la de azotes: «se les hizo poner a cavallo en bestias de alvarda desnudos de medio cuerpo con grillos en los pies y pie de amigo cada uno al pescuezo y manos... Se les llevo por el oficial publico en dichas bestias por las calles publicas y acostumbradas de esta ziudad y su Pescaderia y en algunas partes y sitos les a dado a dos azotes a cada uno publicando su delito de ladrones y asi sacados y llevados hasta mas aca de la Puerta de la torre de Avaxo donde ay un puente ô pasadizo les abuelto repetiendo el mesmo ôficial publico su delito de ladrones... y llegados a la referida carçel real se entregaron a Pedro Alvarez Carvallo alcaide de ella». 


\section{DESAPARICIÓN}

Desde finales del siglo XVIII se fue configurando una conciencia doctrinal contraria a esta pena, rechazada por considerarse propia de épocas a olvidar y por los perjuicios que ocasionaba. En esta línea cabe enmarcar el texto de Pedro Rodríguez de Campomanes, al que se remitía el redactor del informe elevado a la Junta del Reino de Galicia en 1775, cuando afirmaba que:

«la pena de azotes infama al que la sufre y no le mejora. Es contra buenas reglas de política deshonrar al ciudadano cuando hay otros medios de corregirle y de mejorar sus costumbres. Lo peor es que esta infamia recae, según la opinión vulgar, sobre sus inocentes familias, y ellos se abandonan enteramente, sin volver a serles útiles, ni al Estado. Recluidos en casas de corrección, se verá que están libres de ambos inconvenientes. Es una pena, la de azotes, inventada contra los esclavos y poco acomodable a cristianos y hombres libres que descienden de familias decentes, cuales son los españoles»171.

No obstante, tampoco faltaron juristas que propiciaban su mantenimiento dentro de ciertos límites para contener a la población por los males que causaba la imposición de la pena de azotes. Cabe mencionar la posición mantenida por quien fuera fiscal de la Chancillería de Granada, Manuel de Lardizábal, quien se remitía a las afirmaciones que había realizado Matheu en defensa de este castigo, e incluso a la petición efectuada por la Audiencia de Mallorca para su aplicación en aquel reino, en que por privilegio no se podía castigar ningún delito con aquella pena, ya detalladas con anterioridad. A mayor abundamiento sostenía que:

«la pena de azotes, si no hay mucha prudencia y discernimiento para imponerla, lejos de ser útil, puede ser perniciosa y perder a los que son castigados con ella en lugar de corregirlos. Ella es ignominiosa y causa infamia, por lo que sólo debería imponerse por delitos que en sí son viles y denigrativos, pues de lo contrario la pena misma causará un daño mayor, acaso, que el que causó el delito, que es hacer perder la vergüenza al que la sufre y ponerle por consiguiente en estado de que se haga peor en vez de enmendarse. Pero impuesta con prudencia y discreción podrá ser útil y contener con su temor. Por regla general, en una nación honrada y pundonorosa cual es la Española, toda pena de vergüenza usada con prudencia y haciendo distinción en el modo de imponerla, según la distinción de clases y de personas, puede producir muy saludables efectos»172.

Su final normativo comenzó a darse con la Ley de 17 de agosto de 1813, por la cual las Cortes «queriendo desterrar de entre los españoles de ambos

171 Rodríguez De CAMPOMAnes, Pedro: Discurso sobre el fomento de la Industria popular, Madrid 1774 (ed. del Instituto de Estudios Fiscales. Estudio preliminar de John Reeder, Madrid 1975, p. 101).

172 LARDizábal, Discurso, Azotes, pp. 192-196.

Hispania, LXII/3, núm. 212 (2002) 849-906 
mundos el castigo o corrección de azotes, como contrario al pudor, a la decencia y a la dignidad de los que son, o nacen y se educan para ser hombres libres y ciudadanos de la noble y heroyca Nación Española, han tenido a bien decretar lo siguiente: Se prohíbe desde el día de hoy la corrección de azotes en todas las enseñanzas, colegios, casas de corrección y reclusión y demas establecimientos de la Monarquía bajo la mas estrecha responsabilidad». Pero el texto clave es el contenido en la Ley de 8 de noviembre de 1813 en virtud de la cual las Cortes generales y extraordinarias, reunidas en Cádiz:

«convencidas de la utilidad de abolir aquellas leyes por las cuales se imponen a los españoles castigos degradantes, que siempre han sido símbolo de la antigua barbarie, y vergonzoso resto del gentilismo, han venido en decretar: $1^{\circ} \mathrm{Se} \mathrm{decla-}$ ra abolida la pena de azotes en todo el territorio de la Monarquía española. $2^{\circ}$ Que en lugar de la pena de azotes se agrave la correspondiente al delito por que el reo hubiere sido condenado; y si esta fuere la de presidio u obras públicas, se verifique en el distrito del tribunal, cuando esto sea posible. $3^{\circ} \mathrm{La}$ prohibición de azotes se extiende a las casas o establecimientos públicos de corrección, seminarios de educación y escuelas. $4^{\circ}$ Estando prohibida la pena de azotes en toda la Monarquía, los párrocos de las provincias de Ultramar no podrán valerse de ella, ni por modo de castigo para con los indios, ni por el de corrección, ni en otra conformidad cualquiera que sea. $5^{\circ}$ Los M.RR. Arzobispos, Obispos y demás Prelados ejercitarán con toda actividad el lleno de su zelo pastoral para arrancar de sus diócesis cualquier abuso que en esta materia advirtieren en sus párrocos, y procederán al castigo de los contraventores con arreglo a sus facultades. $6^{\circ} \mathrm{Del}$ mismo modo procederán los Prelados eclesiásticos contra aquellos párrocos, que traspasando los límites de sus facultades se atrevieren a encarcelar o tratar mal a los indios».

Como se puede advertir con facilidad, la primera de estas normas pretendía desterrar los azotes en su modalidad de medio correctivo; mientras que la segunda iba mucho más lejos al abolir la pena de azotes.

A pesar de la norma transcrita, la desaparición de esta pena fue producto más del desuso que de disposiciones legislativas. Una Real Orden de 25 de agosto de 1834 prohibía esta forma de corrección de las escuelas, por considerar que este modo de corregir era «contrario al pudor y a la decencia, y envilenciando tanto al que lo impone como al que lo sufre», disponiendo su abolición y sustitución por medios de emulación y ejemplo.

No obstante, el art. 11 del Reglamento provisional para la administración de justicia de 26 de septiembre de 1835 aun llegó a enumerar, entre las penas corporales, la de azotes junto con las galeras, entre otras, sin duda debido a un anquilosamiento en la tradición, sin que tuviera mayor transcendencia. Por el contrario, el Código penal de 1848 y los textos que le siguieron no hicieron ninguna alusión a tal execrable castigo. 


\section{CONCLUSIONES}

Los azotes fueron, junto a la pena de muerte, uno de los castigos de más larga trayectoria histórica y con más amplia representación territorial. La variedad que se dio en su imposición numérica derivó en una distinción cualitativa: si su número era inferior a veinticinco, los azotes tuvieron la consideración de simple corrección; pero si sobrepasaban los cincuenta ya se alcanzaban el rango de pena.

Si concentramos nuestra atención en su condición de castigo corporal descubriremos que presenta incorporada a su esencia misma dos aspectos sustanciales que la aproximan a otras dos penas: por el rastro que dejaban en el cuerpo fue una marca pero, a diferencia de las más habituales, de fácil ocultación y no necesariamente vitalicia; de modo paralelo y al menos en la Corona de Castilla, su ejecución ordinaria conllevaba en sí misma la pena de vergüenza pública, con el consiguiente grado de ignominia. Por ello, desde la perspectiva estamental de los siglos bajomedievales y modernos fue una pena establecida para del estado llano, sobre todo para los considerados viles y a los que tan sólo restaba imponer la pena capital. En la representación ritual de su ejecución siempre fueron necesarios tres actores: el oficial de la justicia, quien manifiesta el triunfo del rey y su orden; el pueblo, que presencia de forma activa su cumplimiento; y, el reo, que padece en sus carnes, públicamente, por sus delitos.

Por otra parte, ha sido habitual señalar, sin argumento jurídico que lo avale, que la pena de azotes era accesoria de otras. A ello pudo contribuir la redacción de algunas disposiciones regias que situaban a la que nos ocupa inmediatamente detrás de la pena de galeras o de destierro. En mi opinión no cabe tal apreciación por ser más propia de la codificación que de los siglos anteriores. Cuando las disposiciones de Felipe II, por ejemplo, fijan como castigo de un determinado delito un número de años de galeras o de destierro y otro de azotes no puede considerarse que sean dos penas - una principal y otra accesoria- sobre ese único hecho delictivo, es una única pena compuesta de dos castigos diferentes. Diferente cuestión es que el arbitrio judicial influyera en la reducción de una u otra, o en la exención de una de ellas. Sin olvidar la posibilidad de conmutación de la pena de muerte por el remo y la fustigación.

La larga trayectoria histórica de los azotes influyó, sin duda, en el amplio abanico de delitos para los que estaban señalados, de lo cual es buena muestra tanto las Partidas como los textos legislativos recopilados. En el ámbito judicial gallego de la Edad Moderna se empleó para la represión, fundamentalmente, de tratos carnales ilícitos, de conductas delictivas que versaban sobre armas, resistencias a la justicia, fugas de presos y, de manera muy destacada, para toda clase de hurtos, máxime si su autor era tachado de ladrón famoso.

Su evolución histórica permitió la aparición de diferentes modalidades de ejecución, con independencia de las similitudes existentes entre territorios de influencia del Ius commune. Para ciertas conductas delictivas existieron modali- 
dades tradicionales donde al dolor físico se unía la mofa del pueblo; aunque en otros supuestos eran los propios juzgadores quienes se encargaron de agravar su cumplimiento amparados en su arbitrio judicial. No obstante y al menos por lo que respecta a su aplicación efectiva en Galicia, en comparación con otras penas consideradas en sí mismas, representó un porcentaje relativamente reducido.

En su lenta desaparición de los textos normativos influyeron variadas circunstancias: el rechazo de penas con larga tradición, de gran dureza y que conllevaban, además, la nota ignominiosa; la necesidad de respetar la dignidad humana e imponer una represión punitiva acorde con el mal causado; y, la introducción de nuevas concepciones penales en pos de convertir la pena de prisión en la pieza clave de todo el sistema, propiciando una posible prevención de actividades delictivas y enmarcando los castigos en la corrección del delincuente por vías diferentes a las de rancia raigambre romana. 